\title{
Experimental Studies on Adreno-cortical Proliferation
}

\author{
By
}

\section{Shirô Higashimori}

(From the Department of Pathology, Faculty of Medicine, Kyoto University; Prof. Shigeki Mori)

There are two conflicting concepts about the cells of the adrenal cortex. One is the escalator or cell-migration theory formulated by Gottschau. According to this theory, the growth of the cortex takes place in the outer part of the cortex and the cells originate from the capsular fibroblasts and gradually migrate inwards towards the medulla until in the zona reticularis they degenerate and are removed. The second is the so-called zonal theory advocated by Deane et al. Deane and Greep firmly believe that the zona glomerulosa and the zona fasciculata of the adrenal cortex are different in structure, origin and function.

In this paper, the author discussed the nature of the cortical cells especially the proliferation of the cortical cells.

\section{Chapter 1. Regenerative process of rac's adreno-cortical cells after adrenal enucleacion.}

1). After adrenal enucleation, rats lived for a long period without any cortical deficiency syndrome, and the body weight was greatly increased. Even a few cortical cells regenerated from the capsular regions, could secrete enough ccrtical hormone to maintain life.

2). By means of colchicine, the author observed the mitotic activity in the capsular regions soon after the operation. Later, the mitotic activity were somewhat deceased in the capsular regions, but increased in all the other regenerated cortical cells.

This experiment of adrenal enucleation, suggests that cortical cells apparently proliferate from capsular cells.

3). The author concludes that there are 4 types of cortical regeneration after adrenal enucleation:

1. Mitotic division in the capsule.

2. Metamorphosis from capsular cells.

3. Mitotic division in the cortex.

4. Metamorphosis from blast cells in the cortex.

\section{Chapter 2. The problem of adreno-cortical autonomy.}

After hypophysectomy, the zona fasciculata and the zona reticularis were atrophied in rats, whereas the zona glomerulosa did not show any change. It is generally accepted that glucocorticoids are secreted by the zona fasciculata by stimulated the anterior pituitary adrenocorticotrophic hormone, and mineralocorticoids are secreted by the zona glomerulosa which is not under hypophyseal control.

In the author's experiment of adrenal enucleation in rats, the cells of the zona glomerulosa showed autnomous proliferation even in the hypophysectomized rat. The histochemical findings in these regenerated cells, suggest to the author, autonomous secretory activity in the zona glomerulosa also, the cells of the zona fasciculata however, did showed no proliferation in hypophysectomized rats.

Chapter 3. The influence of various hormones on adreno-cortical proliferacion.

1). After adrenal enucleation, rageneration of adreno-cortical cells was stimulated by ACTH injection, or other hormones provoking anterior pituitary ACTH secretion (estrogen). These results show 
that anterior pituitary adrenocorticotrophic hormone controls the proliferation of cortical cells.

2). But in addition to ACTH, growth hormone and testoids stimulate adrenal regeneration markedly. So ACTH is not the only tropic hormone for the adrenal cortex.

3). Gortisone depressed the regeneration of the adrenal cortex, and this effect acts through anterior pituitary depression. DOCA did not depressed adrenal regeneration, because of its milder pituitary depressive action as compared with cortisone.

4). In female rats, the regeneration of cortical cells is somewhat depressed by gonadectomy.

5). This experiment shows that all cortical cells seem to proliferate from the same capsular origin. In the early stage of regeneration, the zonal difference was indisinct. But in later stages, regenerated cortical cells show different zonal functions.

\section{Chapter 4. Hormonal influence upon regeneration of the zona fasciculata.}

1). The cells of the zona fasciculata could regenerate when the anterior pituitary was present. And ACTH seemed the only factor in the regeneration of the zona fasciculata. The cells of the zona glomerulosa seem to be transformed into the cells of the zona fasciculata under ACTH influence and acquire the ability to secrete glucocorticoids.

2). Growth hormone, testoids and chorionic gonadotrophin did not transform the cells of the zona glomerulosa into cells of the zona fasciculata in this experiment. 


\title{
副腎皮質增殖に関する実験的研究
}

\author{
京都大学医学部病理学教室（指導 森 茂樹教授）
}

研究生東森四郎

本研究要旨は, 第 5 回及び第 6 回日本病理学会西部地方会, 第43回日本病理学会総会, 第 27 回日本内分泌 学会に於て発表した。尚, 内分泌のつぞい第 7 集森, 安藤一副腎皮質の機能的子形態学一に本諭文の一部紹 介発表あり。

\section{目次}

はしがき

第 1 編 ラット副腎 Enucleation 後の副腎 皮質紐胞の再生過程について

第 1 章 緒菩

第 2 章 実験材料及び笑験方法

第 3 章 实験結果

第 4 章 考案

第 5 章 要 約

第 2 編 副督皮質の自律性

第 1 章 緒夆

第 2 章 実験材料及び実験方法

第 3 章 実験結果

第 4 章 考案

第 5 章 要 約

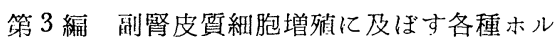
モンの影響

\begin{tabular}{|c|c|}
\hline 第 1 章 & 緒 \\
\hline 第 2 章 & 実験材料及び実験方法 \\
\hline 第 3 章 & 実験結果 \\
\hline 第 4 章 & 考 \\
\hline 第 5 章 & 要 \\
\hline
\end{tabular}

第 4 編 束状帯細胞再生増殖に及ぼす 2 及 ホルモンの作用について

第 1 章 緒蒠

第 2 章 実験材料及び実験方法

第 3 章 実験結果

第 4 章 考 案

第 5 章 要 約

第 5 編 全編の総括

引用文献

写 真

\section{はしがき}

1855年 Thomas Addison が Addison 氏病なる疾患が副堅特に皮質と密接な関係のあるてとを唱えて以来， 副筒が次篛に注目世られるようになつた。 1856年 Brown-Séquard が副腎剔出に関する実験的研究を初めて 行い，全副緊を剔出すると間もなく動物は死しするが，副腎を移植するととにより，一定期間缺落症状の発 生を阻止し得るととを報告している。しかしての追試成績は極めてまちまちであり，両側副腎か浣全に壊さ れた場合にも，アヂソン氏病の幑候か溌現しない場合がしばしば認められた。この理由は，傍副腎か代償性 增殖を惹起し，または残存皮質の小組織わ機能を代償するためと考えられる。その後 Adrenalin か䯩峰， Aldrich (1901) により分離され, Adrenalin の構造, 合成, 生理学的機序, 薬理学的作用の面に研究が尚け

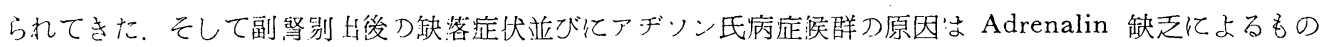
とみなされてきた。

その㷋，副腎皮質が生命保持に絶対必要でらるが，髄質は然らざる点が判明するに及び，再び皮質が重視

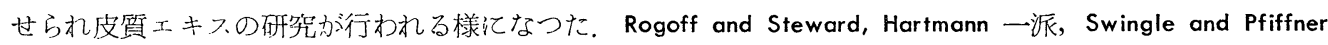
等により，副腎剔出動物の生命延長に有效な皮質エキスか抽出され，次で Grollmann and Firor，Kendall， Winterstein 等は純結晶性物質を得るに到り，本物質がステロイドホルモンであるてとが分り，皮質より出さ 
れるステロイドは一般にコルチコイドまたはコルチコステロイドと呼ばれるに到つた。

副腎皮質ホルモンは生理学的機序の上から，糖質コルチコイド (Glucocorticoids) と鉱質コルチコイド (Mineralocorticoids) 及び性ホルモン作用を有するコルチコイドとに大別するととが出来る。氻る作用の 異つた副腎皮質ホルモンは，副腎皮質の如何なる細胞より，また如何なる機鏳の本に分泌されるか，その全 貌は今日未だ明かでなく，副緊皮質ホルモン分泌機序の問題に関しては，従来数多くの議論がある. Selye

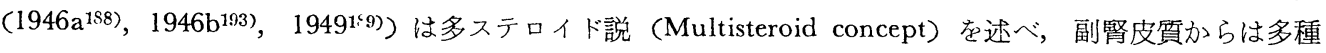
類の亦ルモンー Glucocorticoid, Mineralocorticoid, Lipocorticoid, Testocorticoid 等が分泌され, 生体 の要求に応ずるものとしている。乙れに対して Sayers (1948179)，1950180)，Feldman (1951) ${ }^{7+)}$ は単一説 (Unitarian concept) を主張し，副腎皮質からは唯一種類のホルモンのみか汾泌され生体側の状態に応じて 種々異つたホルモン作用を発揮するものとしている。

一般に副腎皮質機能は，他の内分泌腺機能より下垂体に高度に支配されている(Smith 1926, Smith 1930) ${ }^{2(0)}$. そして副腎皮質は下垂体一副腎皮質系として，生体の防禦機序に重大な役割を有するてとか知られて 来たが，下垂体と副腎皮質機能との相互関係についても前述の副腎皮質分泌機序と絡んで，多くの議論が存 在する. Li, Evans and Simpson (1943) ${ }^{140)}$ は純粋の Adrenocorticotrophic Hormone (以下 ACTH と略す) を分離したが，Sayers (1948) ${ }^{179)}$ はかかる ACTH か㨽腎皮質機能す心゙てを支配するという，下垂体副腎皮 質系一元論を述べている. 即ち，下垂体前葉からは副腎皮質を支配する唯一種類の向副腎皮質刺㦸ホルモン か汾泌され，てれに対して副腎皮質からは唯一種類のコルチコイドが分泌されるというのである。一方 Albright 一派 (Reifenstein, Forbes, Albright, Donaldson and Corroll (1945) ${ }^{172}$ ), Albright (1947)4), Talbot, Albright, Saltzman, Zygmuntowicz and Wixon (1947)20(i), Albright and Reifenstein (1948)5)は及びSホルモ 之説 ( $\mathrm{N}$ and $\mathrm{S}$ Hormone concept) を述べ，副腎皮質はCの11及び17の位置に酸素を有する Cortisone様 作用を発揮する S-hormone と，Testoid 様作用を有する N-hormone を分必し，何れも下垂体の支配の下 で分泌されるものとしている. 即ちACTHは S-hormoneの分泌を, LH (Luteinizing hormone) は N-hormone の分必を支配するものと考えている.

他方，副腎皮質を組織学的観点よりみると，増殖と関聯し、て種々の問題が存在する，哺乳動物の副腎皮質 は一般に細胞の配列，血管，結合織の関係汃ら Arnold (1866) ${ }^{11}$ によつて三層 (球状率 Zona glomerulosa, 束状帯 Zona fasciculata, 網状带 Zona reticularis) 亿分類されているが，てれら各層か泇何なる機能的意 義を持つているから゙興味ある問題として議論されている.

従来，副腎皮質細胞は副腎皮質の周辺部加ら增殖して，次第に内方に移動し内酋部の細胞と打き代り，網 状帯で変性死滅するものと考えられている。乙の説は所謂 escalator または cell-migration theory と称せ られるもので,己に1883年 Gottschav83) 以来汃る説力湜案されている。 それ故網状带は Zona consumptiva

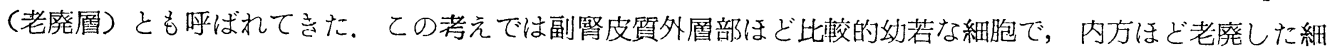
胞とみなされるものである。また Bennett(1940)吕) は副腎皮質を，細胞の life cycleまたは secretion phase の上加ら分類し, 球状带を presecretory zone, 束状帯外㜿を secretory zone, 束状帯内凰を postsecretory zone，最内風を zone of senescence と呼び，球状帯は皮質細胞の準䚚風であり，真の分泌尿は 束状帯であるとしている。乙れらの人々は副腎皮質三圆は secretion phaseの相異を示すものとしての意義 を認めているが，副腎皮質三尿は種々環境下に於て，常に必ずしも平行協同的な変化定示すものとは限らず， 時には全く異つた反応態度を示す場合がしばしば認められている. 特にBennett (1940)苜)以来, 諸種の組織 化学的検索力㨽㹂に応用されてきて，各層の機能異質性の問題か取り上げられる様になつた。そして種々の 染色所見から球状帯の変化は，他の皮質風とは独立的な変化を示すものであると認められて来た（Yoffey

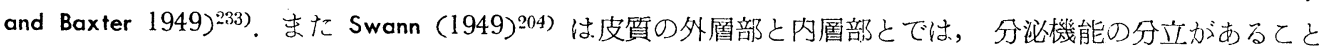
を想像している. 更に Weaver and Nelson (1943)21-は少くとも球状带と束状帯の二個所に於て, 重屈折性 物質の放出（一般に皮質ホルモンの分泌と関聯）方行われるととを述べている。

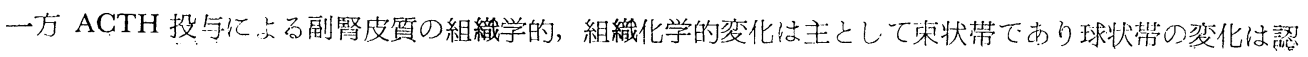


められないか，或いは極めて軽微である(Bergner and Deane 1948³), Ducommun and Mach 1949) ${ }^{61}$. 下垂体 剔出によつて束状带, 網状帯が高度に萎縮するに反し, 球状帯は殆んど 萎縮しない (Deane and Greep $1946^{(i)}$, Jones 1950 $)^{119)}$. そして球状带は諸種の塩類 $(\mathrm{Na}, \mathrm{K})$ 失調で撰扢的に変化か懑起される点より, 球状带は下垂体の支配を受けずに自律的に鉱質コルチコイドを分泌するものと考えているものが多い，それ に反して束状帯は ACTH の支配の本に糖質コルチコイドを分泌するもので，とてに Deane and Greep (1946) の副堅皮質の二元論が主張されるに及んだ．Deane 一派によると球状帯と束状帯とは機能, 形態 立でに origin 共に全く異つた組成より成り立つていると考えている. てのDeane 一派の二元論と上述 escalator theory (一元論) とは全く矛盾する説であるが, 今日此等諸問題に対して明確な解答は全く与元 られていない.また Albright (1947) は網状带は下垂体の Gonadotropin に支配されていると述べているが， 網状带も他の二層と同様に重要な課題となつている. さて以上諸問題を要約すると, 次の三つに分けられる.

(1) 副堅皮質の下垂体前葉ホルモンによる分泌支配の問題

(2) 皮質各層の機能的意義

(3) 皮質各層細胞の增殖の問題

副㹂皮質ホルモン分泌機序として，束状帯のみが分泌機能を司る分泌凰であつて，ての層から一種類の木 ルモンが分泌されるという兒方は escalator theoryにも，また Sayers 一派の所謂下垂体副腎皮質一元諭に も極めて上く当てはまる説である。然し，実際副腎皮質から分泌されるコルチコイドは決して唯一つのホル モンではなく，糖質コルチコイド，鉣質コルチコイドの他に男性ホルモンの分泌か行われているという見方 か強い，近年副粲の灌流実験等により，強力な鉱質コルチコイドAldosterone (Electrocortin) の存在か確 められて，鉱質コルチコイドの分泌は最早疑う余地なき迄に至つている (Grundy et al 195292), Simpson and Tait 1953198), Mattox, Masson and Albert 1953150), Farrell and Richards 195373), Desaulles, Tripöd and Schuler 19535), Gaunt et al 195478), Gross 195488), Gross and Gysel 19548.7), Luetscher and Johnson 1954144). しかし一方皮質ホルモン分泌機序には他の可能性も考えられている. 即ち副腎皮質は生理 的に少くとも電解質・水及び糖代謝の二つの作用がみられるが，てれはホルモンの量的相異に基くものでは ないかという可能性である (Swann1940)20 i). 即ち下垂体剔出動物に於て糖質代謝が㧊かされ，塩類代謝が保 持されるのは，下垂体剔出動物副㛑は塩類・水代謝機能を保持するには充分なホルモンを出すが，糖質代謝 を保つ量には達しないのではあるまいか。.また副腎皮質の外層部で作られたホルモンが, 内首部に運ばれて， そこで化学的に塩類代謝機能に加うるに糖質代謝機能をうる様になる可能性も考えられている（Swann 1940) 204$)$.

ともあれ組織形態学的に，副腎皮質各首は異つた機能を有するものか，各層細胞力独立的に増殖するのか， または同じ細胞であつても異つた機能相を示すものなの加等の問題は, 極めて重大な課題であつて，私は Enucleation の実験法り，乙れら諸問題の分析的検索を試みたのである。 そして副腎皮質細胞の增殖形式 と下垂体ホルモンとの関聯に於ける, 特に球状帯細胞と束状帯細胞の形態学的並びに機能的意義の解明を, シットについて検索してみた。

\section{第 1 編 ラット副婜 Enucleation 後の副腎皮質細胞の}

再生過程について

\section{第 1 章 緒}

\section{$\overline{\overline{\bar{D}}}$}

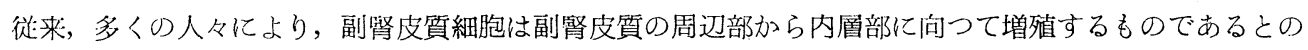
見解か沶されている。即ち皮蹃部に於ける皮質細胞の変性死滅を補立するために，周辺部から新たに皮質細 胞か增生されるという考えである。この見解の根底をなしている事実としては, 副箐皮質周辺部には此較的 核分裂像が多人, 内䅉の網状帯には一般に細胞の变性, 崩壊像が多いという風的分布に由来している。既に 
1883年, Gottschav83)かかかかる移動堌殖形式を提唱して以来, ての分野に於て仿扎びだだしい研究が行われて いる. Conalis $\left.(1887)^{35}\right)$ は，ウサギ等について，周辺部に核分裂像が多い点から全く同様の結論を出し， Mulon (1903) ${ }^{161)}$ は副腎皮質各層の核分裂像を観察し，間接分裂と直接分裂力球状带と束状帯の外層部に認 められるととを述べている。併し乍ら，一方皮質細胞の分裂能力は皮質内首部に於ても保持されているとと も知られている (Bernard and Bigart 190224), Wiesel 1902:19), Cellestino da Costa 191338), Baxter 1946)21). Haber (1908) ${ }^{933}$ は犬，ネコ，ウサギに於ては束状帯に多数の分裂像を見出し，てれらの学者の中には束状帯 の部位加ら逆に外方に増殖するとみているものもいる。しかし Kolmer (1918130),1919131) 敒分裂像の最も多 数出現する部位は, 束状帯と球状帯との間であると述べて打り, Baxter (1946) ${ }^{21)}$ は被膜ら2 3 個細胞の深 さの球状帯部に多いと述べている。 また Bachmann (1939) ${ }^{16)}$ は人体例に於て, 分裂像は被膜直下に最も多い としている. Graham (1916) ${ }^{8-1}$ はクロロホルム麻酔で副腎を傷害した場合には網状帯に多数の細胞変性像が 出現する一方, 球状帯と束状帯の外首部に最も多数の核分裂像が出現する事実を挙げている. 特に Stress または ACTH 投与時には球状帯と外束状帯に核分裂像の増加する点か諗妨られてい (Anselmino, Herold and Hoffmann 19349), Weber 1938215), 大桶 19551'5)). 然し乍ら副腎皮質の核分裂は動物により著しい差異

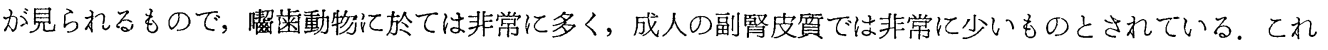
らの点より，副腎皮質の増殖は核分裂のみでは説明が出来ないもので，直接分裂または metamorphosis に よる增殖が大きな役割を占めるものと思われる．乙の点で最も重要な課題となるのは，皮質細胞の胚芽自の 問題である，ての問題についてもかなりの議論があり，肧芽居を被膜の内首と々なすもの，球状带とみなす もの, 球状带と束状带心移行部とみなすもの等種々の主張があるが, これらの内でも特に被膜内層部か肧来图

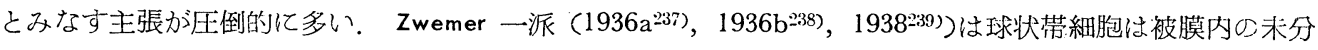
化線維芽細胞様の紐胞加ら発生し, 内方に堌殖するに従い, 次節に皮質細胞心形態をとり，リポイド顆粒を

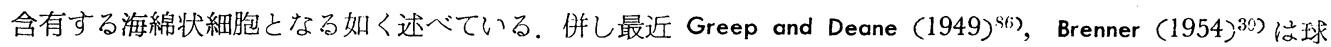

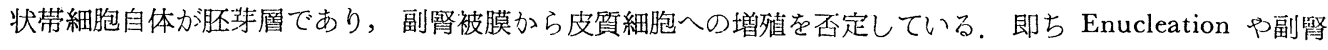
移植にみられる再生期に，被膜細狍は何等核分裂等の増殖態度を示さない点を挙げている。とてろが同じく Enucleation の観察に於ても，Baker and Baillif 193819)，193920) は被膜細胞が分裂像を示すととを述心てい る。乙の様汇被膜が皮質細胞の増殖源であるか否かていいても賛否両論がある。

副腎 Enucleation は副腎被膜の及残して (少数の球状带紐胞つ残存はまぬが㣗得ない), 皮質, 随質共に 剔出する方法で, その後短時日の間に皮質細胞が元通りに再生される。乙の点, 副袩皮質細胞の增殖過程を 恰索するには，最も適した方法と思われる，私か㨽珡皮質細胞の增殖過程検索に，敢えてての Enucleation の方法を撰んだ所以も此の点にある。

\section{第 2 章 実験材料及び実験方法}

実験動物としては体重100〜150grの雌雄ラットを使用した。副珡 Enucleation は Evans (1936)'9), Ingle and Higgins (1938 a, $)^{1091}$ の方法及び大森 (1951) 16:) の副㛑剔出術及び 被膜並びに Zona glomerulosa 残

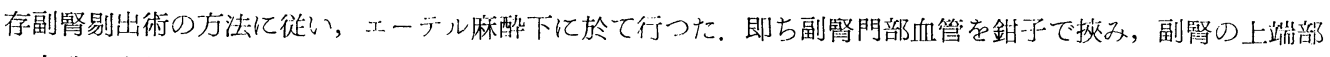
に小孔を穿ち, 内部の皮質甠質を共に圧出し, 生理食塩水で被膜囊内を数回洗滌し, 殆んど皮質細胞の残存

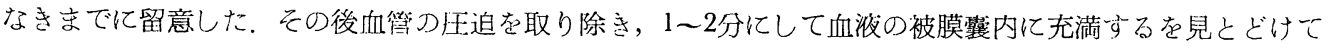

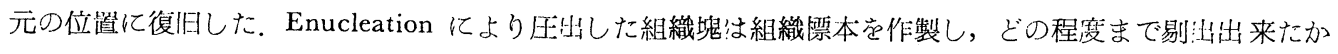
を鏡罗により確めた。

尚動物は術後の感染を予防するだめ水溶性結晶ペニシリンGを投与し, 副腎不全の予防のため1\%食塩水 $5 \mathrm{cc}$ 岸皮下に投与 ( 2 日閌) した。

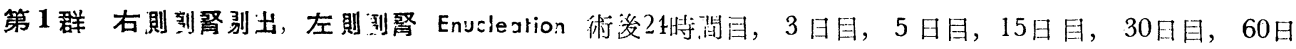
目のもの各例雌雄 3 凹こづつ, 特に15日目のものは雙雄15匹づつにつき桧索した。

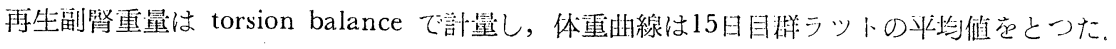


副腎はブアン固定と，10\%中崖ホルマリン固定を施し，ブァン固定のものはパラフィン切片として，八マ トキシリン・エオジン, 一部はマツ・ン染色, アザン染色, ワンギーソン染色を行つた。 中性ホルマリン固 定のものは氷結切片により, Sudan IV, Schiff, Schultz一部は重屈折性, Nile blue 染色を行い検索した。

\section{第 2 群}

i）右側副肾残存, 左側副腎 Enucleation

ii) 両側副堅 Enncleation

各雄ラット 5 匹づつを使用し，すべて15日目のものを検索した。

\section{第3 群 コルヒチン投与群}

右側副腎を剔出し，左側副腎 Enucleation を行い，コルヒチン $0.1 \mathrm{mg}$ 屠殺 9 時間前に皮下注射により， mitotic cycle metaphase の初期们抑制して，兰の出現及び分布を検索した。

ラットは Enucleation 後24時間目，3 日目，5 日目，10日目に殺し，ブアン，カーノイ固定，へマトキ シリン・エ年ジン染色，メ:レン・ブルー染色により核分裂像を観察した。

第 4 群 i) Thorn test ii) $\mathrm{NaCl}$ 及び $\mathrm{KCl}$ 投与

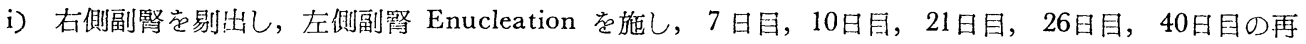
生期に検索した，水溶性 ACTH (Amour) $5 \mathrm{mg}$ 芭使用し，その投与前及び投与後 3 時間後の血中好酸球を

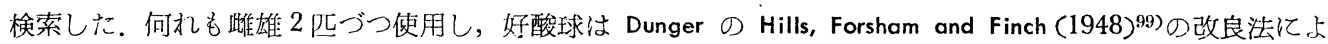
り, この平均值をとつた。

ii）副腎 Enucleation 後 $3 \% \mathrm{KCl}, 3 \% \mathrm{NaCl}$ 各 $3 \mathrm{cc}$ 連日皮下投与し，15日目に屠殺した。また他の 群は Enucleation 後 30 日を経過後, 初当て $3 \% \mathrm{KCl}, 3 \% \mathrm{NaCl}$ 各 $3 \mathrm{cc}$ 更使連続 15 日間皮下投与し屠 殺した。

何れも雌雄 5 匹づつ使用し，副篮はブアン固定，中性ホルマリン固定によりハマトキシリン・エオジン染

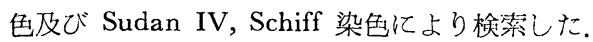

\section{第3章 実 験 結 果}

第1 群 手術後最初の1〜2日間は $1 \%$ 食塩水の経口投与に上つて副㹂皮質機能の脱落を防いだが，3 日目 加らは食塩水の投与を中止した。併し手術ラットは何等副简不全の徴を示すととなく，一般状態も極妨良 好であり，体重も手術直後よりかなりの 增加在示した。. 小数例に於て, 手街後 2 〜3 日後死亡したものがあつたが，乙 れ等注特伦壬術時出血の著明なものや， 一般状態の概して不良な動物であつた。

\section{体 重 曲 線}

一侧副腎剔出，他側副婜 Enucleation のラット体重曲線は，初め20日間位は正 常ラット以上の体重上昇を示した（第 1 表)、しかもかかる体重の增加は特に雄 ラットに於て顕著なものが認められた。 刘照例として而僛副韰全剔:出のラット体 重州線を検べたが，汃かる群は初期より 体重は著明に減退し，且つ一般状態は㤠 化の傾向をたどり，2週間前後に於てそ の大半か㪴亡した。 即ち副腎 Enucleation の易合汢副峄别出刀場合とは全く
第1 表 副珡 Enucleation ラットの体重曲線

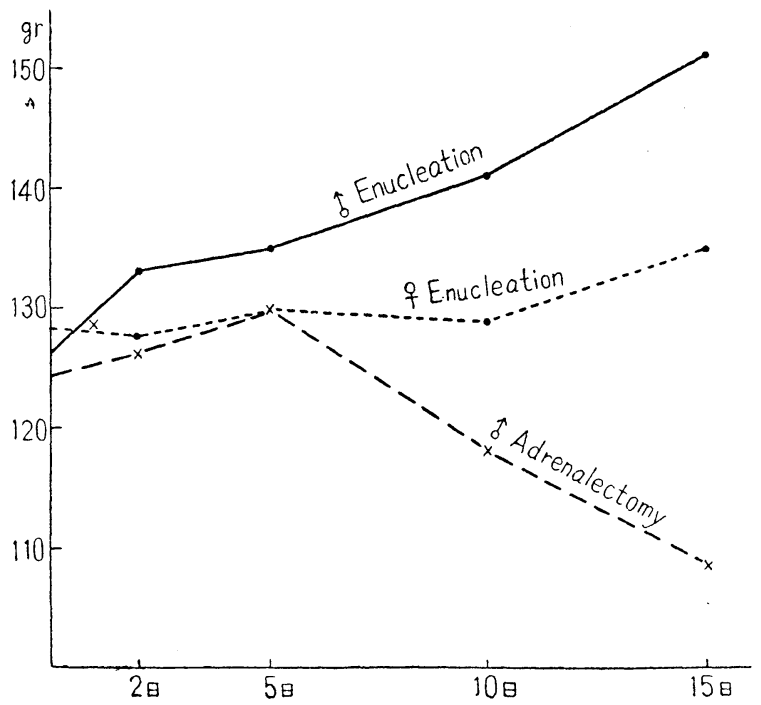

第 32 巻 第 1 号 
異り，急速に副腎機能が恢復されることが想像出来る。副腎全剔出群に於ても小数例のものが長期生存し得

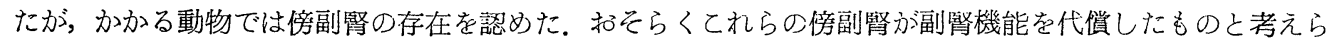
れる。

\section{再生副腎重量}

術後，副婜被膜内には著しい出血があり，血腫状を呈し，従つて重量も異常に大きい，術後 7 日白位で， てれらの血腫は次第に吸収されるが，真の副腎のみの重量ではない. Hartman, Brownell and Knouff (1947)9i) はマウス Enucleation 後7日目で副腎はかなりの血塊で占められているためての時期の副腎重量は真の重 量を示さないとしている。しかしての実験で15日目に於ては，殆んど副㛑自体の重量を示すと思われたの で, 表は15日以後の重量を揭げた。第 2 表, 第 3 表の如く術後 15 日目に於ける再生副腎の平均重量は 7 9 mg

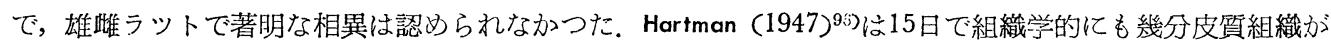
増加し，正常の副腎の3纪をるとしている，術後30日後に扔いてはかえつて元の副腎重量より大きくなり， Ingle and Higgins (1938)109) も5〜6週で14〜16mgなる值をのべている. 60日後に於ては正常ラット左右 副腎合計重量をはるかに凌駕するに至る。

\section{再生副腎の外景}

再生副粲の外観は略球状を呈するが, 一般に不規則な形態を示す。しばしば副 腎周囲脂肪組織内に，黄白色の傍副腎の 発生を認めたものが，かなりの頻度にあ つた。 また再生した副督被膜面に，汃な り大きな被膜腺腫の増生が比校的明確に 第われた。

再生副腎の色調忟一般に正常副腎にみ る如き黄色調に泛しく，多くは淡紅白味 を带び，少さきものは，周囲リンバ腺と 極めて混同し易い外観を呈していた。

\section{組織学的所見}

副腎 Enucleation 後 24 時間後に於て は，副腎は血液の充満した血腫状を呈し，

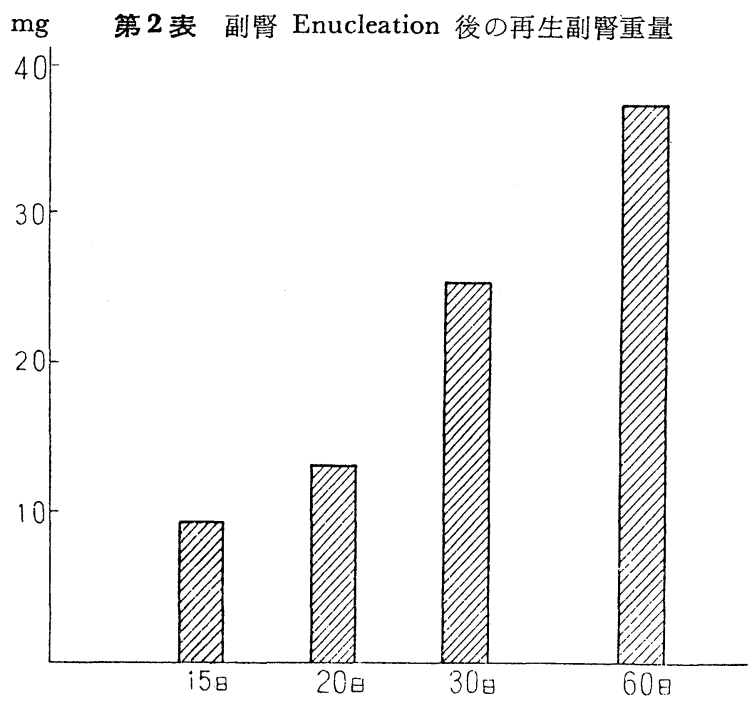

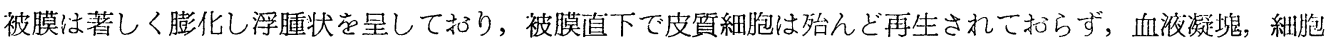
崩壤物白血球の浸潤で占められている。

尚，被膜下の極く少部分に於て，極聇少数の球状带細胞の残存を認》た。乙れら皮質細胞の残存は，特 に周囲脂肪織附着面側の被膜面下にしばしば認めた。一般に此等残存皮質細胞には変性像を認めることが活 来た。

副腎 Enucleation 後 3 日目に於ては, 被膜諒著しく浮腫状で, 被膜細胞も著しい膨化及び空胞化を示し

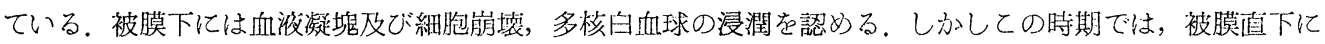

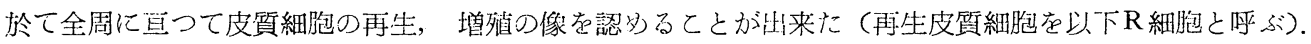

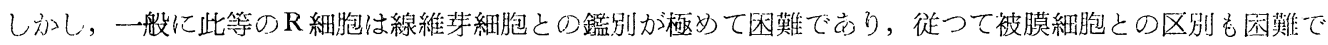

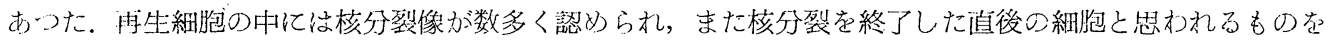

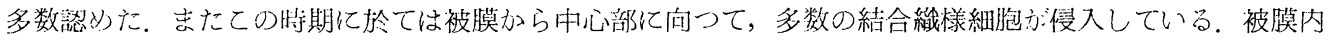

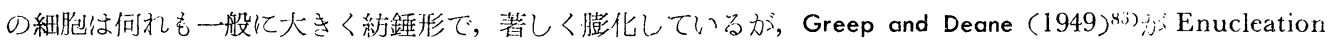

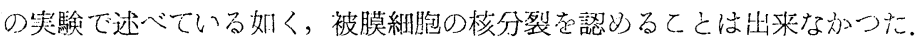

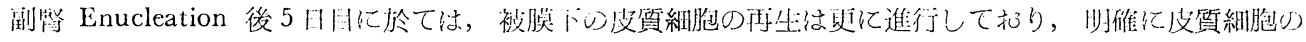

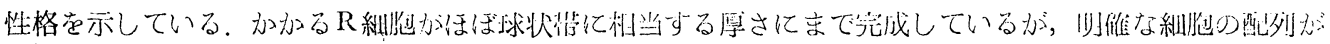




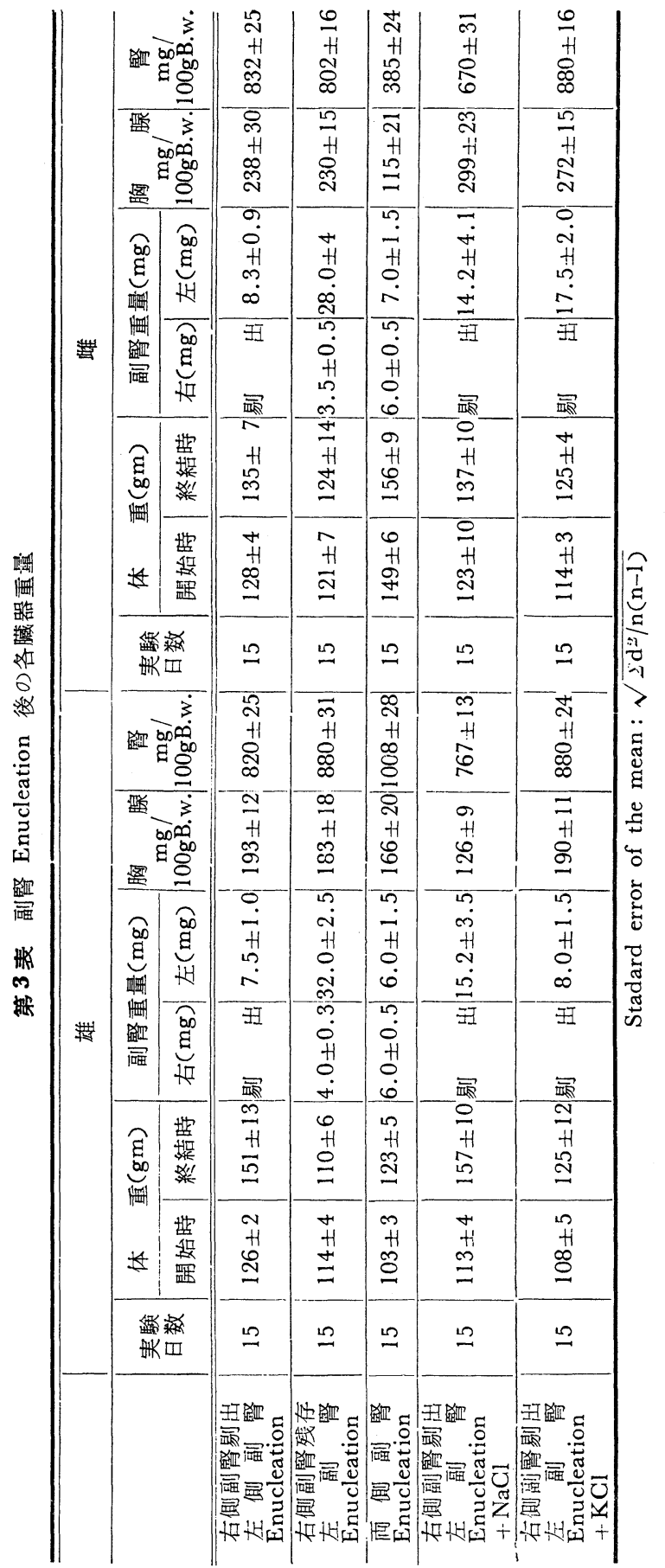

みられず，乙れらの細胞わ球状带細胞办， 宗たは束状带紐胞であるかその区別は明碓 でない。中心部の血液凝塊, 多核白血球は 殆んど吸収，消失して扔り，その場所には 結合織力浸入して中心部を满している。 3 日目群䎲比し, 副婜の形代著しく縮少し, 殆んど被膜，結合織 $\mathrm{R}$ 細胞等の再生成分で 占められている。

副腎 Enucleation 後15日目に於ては， $\mathrm{R}$ 細胞は更に深層部まで完成していた。し 加も内周部の $\mathrm{R}$ 細胞结束状の配列を示し， 明ら加束状带細胞と判定し得る像を示し ている，最内渞部门於ては，然し明確なる 網状帯と認められる譄はなく，血管腔方著 しく拡大している。被膜は Enucleation 後 5 日目のものに比し，かなりうすくなり略 々正常の所見を呈し，細胞も比較的細長て ある. 此の時期の被膜内に於ては，しばし ば黄色の色素沈着を認的た。またた被膜加ら 中心部向つて大量の結合織つ進入を認訲， てれらの結合織は中心部の結合織まで連続 しているものが多い．結合織の增生はかな りの個体差があり，锄物により特に著しい ものがあつた

$\mathrm{R}$ 細胞は一般に，緻密で細胞内特に外㬝 部細胞仗やや粗大な空胞形成の傾向がみら れ，中にはフイブリノイド変性を示すもの があり，そのため特に外渞部は弱拡大では 蜂窄状の構造を星している. 球状带と束状 带との間には移行周 (Engström (1936) ${ }^{68)}$ のいう Grenzschicht, Sarason (1943)17ii) の Clear zone, Mitchell (1948)157) compression）は認めるととが出来ず，ま た球状帯細胞と束状帯細胞とは連続して扢 り，両層を区別するととは組織学的に極め て困難である。併し一般に被膜直下の細胞 ほど少さく，内方に進むに従つて次符に大 きくなつている。中心部は大多数の例䎲於 て結合織または壤死物質で占夘られ，てれ らの結合織内に於て明汃に皮質細胞と思わ れる細胞島が混入している例がしばしば楒められた。また中心部のかかる部位では細胞の配列か不規則であ り，拡大した血管腔を囲んで朋小葉に似た組織像をしばしば認めるてとふ心出来た(写真 4 )。被膜內に於ても

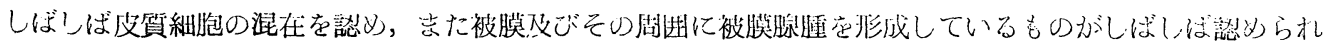


た。てれ等の所見は被膜内細胞または線維芽細胞様の細胞から皮質細胞力洅生されるという説は妥当の樣に みえる。

また被膜腺腫細胞にも田所氏 (1954) ${ }^{207)}$ の述べている如く, 比較的明調な light cell と dark cell との区 別か明膫である，中心部には檤質の再生は全く認めず，血管腔が著しく拡大し，また多数の血管再生も認》 られるが，細胞つ変性・崩壤像は正常副腎の網状带にみる如く著明ではなかつた。

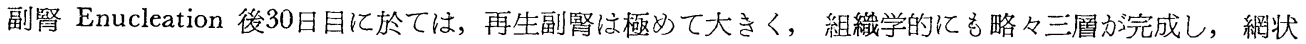
带も判定し得る状態となつている。併し球状帶と束状帯との間には，移行圆細胞は認わられなかつた。何れ

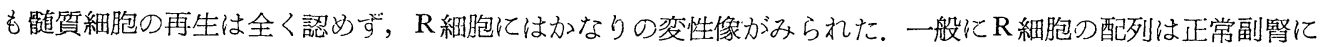
比し非常に不規則であり，彎曲した配列を走すものがるれた。

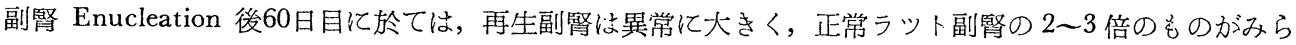
れた，組縕像も略々正常副腎皮質に近いが，数多くの被膜腺腫の形成及び結合織の侵入のため，形虻不整形

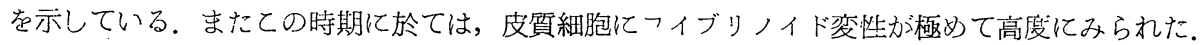

\section{組織化学的所見}

副腎 Enucleation 後24時間目に於ては, Sudan 染色住より中心部つ血波凝塊と, 被膜下の残存球状帯細 胞が僅かに粗大な滴状として染る。

副腎 Enucleation 後3 日目に於ては，R細胞は Sudan, Schiff, Schultz 反応其何れも誃んど陰性である。 被膜内または結合織中に於て, 一部 Sudan, Schiff 陽性顆粒か認妨られた。

副篎 Enucleation 後15日目に於ては，R細胞はS Sudan, Schiff，Schultz 反応で桷慢性にうすく染る程度 で，正常副腎皮質にみられる如き微細顆粒は一部のもの以外には出現していなかつたた。たてれらの組織化 学的所見で，球状带細胞と束状带細胞とは全く同様な態度を示し，而首を区別するととは困難である．勿論 移行層にみられる sudanophobe zone は，雌雄共に兒出し得なかつた。與味㟧るととには，被膜内または 被膜から侵入している結合織内に於て, Sudan, Sohiff, Schultz 反応か強く粗大顆粒状に染る個所がしばし ば見られるのか特異的である(写真 8$)$. 特にてれらの結合織中には皮質細胞つ混入がみられ，一般にみられ る結合織並びに被膜とは異つた性格を思わしめる。被膜脉腫細胞も $\mathrm{R}$ 細胞と略々同栐の組織化学的所見を呈 している， R 細胞の中でも，処々に極めて強く，乙れらの脂肪染色反応陽性細胞が出現しているものがみら れた。 てれらの顆粒は，一般に粗大で散在性に認められた。

副督 Enucleation 後21日目に於てはSudan, Schiff, Schultz 反応力洅生皮質細胞にやや強く出現してて扔

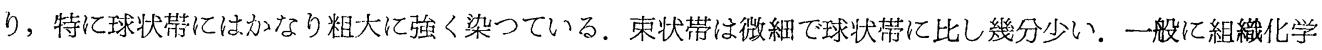
的所見より球状带と束状带との区別は容易であるが，雌雄共に両風の間の sudanophobe zone は明確に認 めることは治来なかつた。またある例では球状带と束状带とは, 上記組織化学的所見で一様の強さに染るも のもあつた．束状带内に於ても比较的粗大な，強く染る顆粒の細胞と弱く染る細胞とか混在していた。

副腎 Enucleation 後30日目に於ては, 球状带, 束状带の区別は諸種脂肪染色で極めて明確であり, しかも 一般にてれら顆粒は增加の傾向を示している。したもての時期に於ても，明確な sudanophobe zone は認め 得なかつた。

副腎 Enucleation 後60日目に於ては, 比較的粗大な顆粒の出現を認㚈, 正常副留皮質に於て認める状態 の顆粒の状態に復していた。

\section{第 2 群 i) 右側副腎残存, 左側副腎 Enucleation 再生副腎重量}

手術後15日目の再生副腎重量は第 3 表に示す如く, 極少少さく, 著しい再生遅延を認沙た。淤し右側副 督の代僧性肥大はかなり著明であつた。

\section{組織学的所見}

右側副腎 (残存側) は著しく肥大し, 特に束状帯細胞が著明であり, 組織化学的にも, Sudan IV, Schiff, Schultz 重屈折性は束状带汃殆んぞ消失し, Deane and Greep (1946) ${ }^{46)}$, Deane, Shaw and Greep (1948)

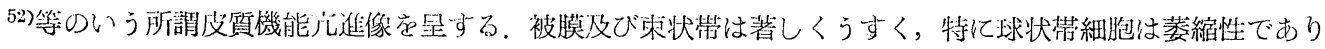


且つ細胞か沍に解離している（写真 9 )。汃るる束状带の肥大は大樋 (1955) 165)の片側副腎剔出時にみられ る他側副腎の代償性肥大の場合と同樣であるが，球状帯の所見が全く異つている，即ち片側副腎剔出時の場 合にみられる他側副珡の肥大時には, 球状带細胞もかなり肥大しているが，ての場合にはかえつて球状带は 萎縮性傾向を示していた。

左側 (Enucleation 側) 副䝳は術後15日目に於ても，再生は著しく遅延され，皮質の厚さはうすく，中心 部まで再生が行われていない，乙の場合被膜仙著しく肥厚して扣り, 被膜直下に於ける皮質細胞の再生は此 較的良好である．作し一般的に R 細胞は萎縮性であり, 特に内首部では粗大空胞を有する脂肪細胞並でに結 合織で占められている(写真10)(ての種つ萎縮性細胞を $\mathrm{D}$ 細胞と以下呼ぶ). 中心部を占めるてれらの $\mathrm{D}$ 細胞 群は, 核は pycnotic で, 一見脂肪細胞に全く類似した変性細胞が主体をなしている. 外側の再生皮質細胞 は Sudan IV, Schiff, Schultz 反応でやや粗大に染るが, 中心部の上述細胞忚極わて粗大な滴状として染る. 特に Sudan IV には強く染り, Schiff, Schultz 反応もSudan IVよりは弱いか洞様滴状を呈する。また中 心部のてれら細胞は Nile blue 染色により, 淡紅色に染る. 中心部のD細胞群仿ちようど下垂体剔出時に みられる萎縮性束状带細胞と類似して扔り，扣そらくは同種類の細胞と思われる。またう汃る種頪の細胞は 第 2 編，第 3 編つ各実験にもしばしば出現するもので，D細胞として夫々の項に於て後述する.

ii) 両側副腎 Enucleation

前者と比へ，組織学的にも $\mathrm{R}$ 細胞つ再生はかなり良好であり，且つかなり内層部まで完成している。また 前群に於て認妨た $\mathrm{D}$ 細胞住, 全く出現していなかつた。組織学的には，リポイド顆粒汭やや粗大の傾问を示 した.

\section{第3 群 副監 Enucleation ラットにコルヒチン注射群}

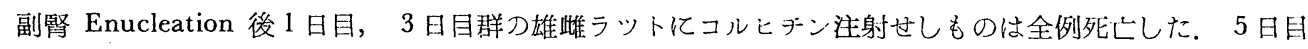
亿於ては，半数は生き残り，10日目群は全例生き残つた，3日目の副腎に於ては，核分裂像汢大多数被膜内

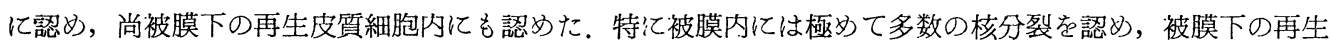
皮質細胞は崩壞像を呈しているものが多かつた。 5 日目のものは被膜内核分裂像は 3 日目群のものよりは少 いが，比較的多く認めることが出来た。尚再生皮質細胞内にはより多数の核分裂像を認めたが，乙れらの細 胞は一般に崩壊像力顕著であつた。10日目群に於ては被膜内の核分裂像汕殆んぞ認めず，再生全首皮質細胞 に於て核分裂を認めた。

\section{第 4 群}

i) 副緊 Enucleation ラットの Thorn test

ii) 副堅 Enucleation ラットに $\mathrm{NaCl}, \mathrm{KCl}$ 投与

i) Thorn test

副督 Enucleation 後各時期に於ける Thorn test に 上る成績は第 4 表の如くである.ラット血中好酸球は 極示個体差があり，好酸球数が著しいひらきがみら れるが，ACTH 投与による好酸球減少率は26日前後 に初めて50\%以上となつた。

ii) $\mathrm{NaCl}, \mathrm{KCl}$ 投与

Enucleation 後翌日より $\mathrm{NaCl}, \mathrm{KCl}$ 連日15日間投 与の場合，副敁皮質細胞再生には殆んどみとむべき所 見がなかつた. $\mathrm{KCl}$ 投与の場合には再生皮質細胞には かなりの変性像がみられ, フィブリノィド変性, コロ イド体の形成がみられた。併しての時期に於ける皮質 外首部は何等肥大及び機能充進像を示さなかつた。 ま た球状带, 束状带は第 1 群と同様な所兒を呈し, 活層
第4表 副腎 Enucleation ラットの $\mathrm{ACTH}$ 投与による血中好酸 球減少

(Amour ACTH5mg 投与 3 時間後)

\begin{tabular}{c|c|c|c|c}
\hline & $\begin{array}{c}\text { 動物 } \\
\text { 繁 }\end{array}$ & 前 & 後 & 判定 \\
\hline \multirow{2}{*}{7 日 } & 2 & 50 & 31 & - \\
& 2 & 20 & 26 & - \\
\hline \multirow{2}{*}{ 10日 } & 2 & 21 & 20 & - \\
& 2 & 32 & 42 & - \\
\hline \multirow{2}{*}{21 日 } & 2 & 3 & 4 & - \\
& 2 & 27 & 26 & - \\
\hline \multirow{2}{*}{26 日 } & 2 & 19 & 3 & + \\
& 2 & 32 & 12 & + \\
\hline \multirow{2}{*}{30 日 } & 2 & 71 & 11 & + \\
& 2 & 49 & 14 & + \\
\hline
\end{tabular}


を区別するととも組織学的に困難であつた． $\mathrm{NaCl}$ 投与ラット再告副腎もかなり再生が良好であり，内風部 の細胞も極妙て大きな形態を是していた，且つ中心部に於ては血管腔が異常に拡大している例がみられた。 また NaCl 投与群の方ものに於て，被膜内に多発性の被膜腺腫を認めた例があつた(写真19).

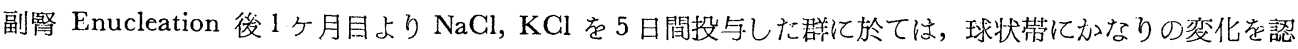
めた. 即ち $\mathrm{KGl}$ 投与により球状帯はやや広く, 細胞も大きく組織化学的にりポイド顆粒は減少, 微細化し 明かに球状帯つ機能元進像を捉えた。 また $\mathrm{NaCl}$ 投与により球状帯細胞行さく，リポイド顆粒は粗大で球 状带機能減退像を思わしめる所見を認めた。

\section{第 4 章 考案}

\section{副腎皮犋細胞の增殖}

副箨皮質細胞は Gottschau (1833) ${ }^{83)}$ 以来上り，所謂 escalator または cell-migration theory か唱えられ 週辺部入ら増殖し，内方に移動するという考えか圧倒的である。けれども皮質細胞の増殖源である，胚牙風 については，被膜及び被膜下となすもの(Zwemer 1936²37) 23), Lux, Higgins and Mann 193711(i), Zwemer，

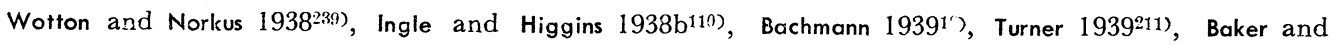
Baillif 1939?), Bennetf 1940:2), Salmon and Zwemer 1941175), Gruenwald 194293), Wotton and Zwemer

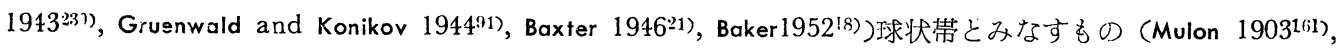

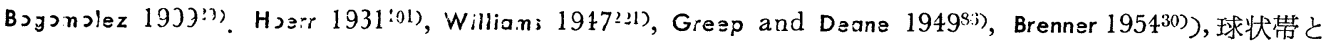
束状帯との移行部とみなすもの (Gnaham 1916 ${ }^{34)}$, Hoerr 1931101), Blumenthal 1940*7), Cameron 195234), また 束状带とみなすもの(Cellestino da Costa 191338)等があり，その見解はまちまちである。乙れらの各主張 は副腎皮質細胞つ核分裂像並びに変性崩壊像の分布・リポイド・ミトコンドリア・Golgi 装置の所見・細胞 学的な見解，各首に出現する reticulum の状態，トリパンブルー生体染色の所見，副腎移植，副腎 $\mathrm{Enu}$ cleation にみられる再生像等の諸種の組織学的，組織化学的検索に基いている，副腎移植の場合は Enucl一 eation と同様，皮質細胞力再生されるものである(Bernstein 195025)，副留移植または副腎 Enucleation 後 にみられる再生機抎岕，正常副腎皮質つ増殖機枟にそのままあてはまるととは勿論出来ないが，諸種環境下

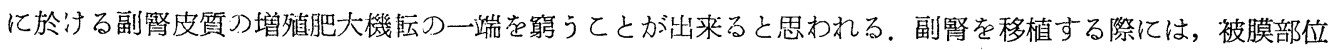
の挿入か泌須であることが述バられて扔り，乙の点から被膜门波質細胞つ再生に重大なる役割を有する点が

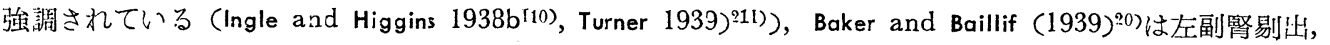
左副婜 Enucleation 後24時間でコルヒテンを投与するととにより被膜內に核分裂像の出現するのを認めて いる。被膜内の核分裂像は同じくNathanson and Brues (1941) 1:3)が Testosterone propionate を投与したラ ツト副留被膜内に於てコルヒチンを投与して認めている。京た正常時つ副腎に於ても，Jayne (1953) ${ }^{117)}$ は

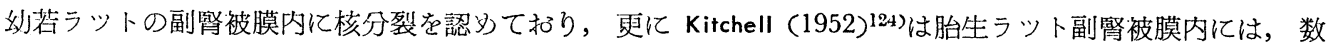
多くの核分裂像が存在することを述べている。乙れらの観察蛙，何れも副筒被膜加皮質細胞つ增殖源である ことを疑つていない.

ところか他方 Everett (1949) $\left.{ }^{72}\right)$ は副婜移植の場合は, 別に被膜の包含がなくとも移植が可能であると述べ て扣り，Greep and Deane (1949)86i愊腎 Enucleation に於て，被膜内には核分裂像は出現せず，Enucl一 eation の際残存する球状帯細胞が皮賲の再生に与るものとしている。また Brenner (1954) ${ }^{30)}$ はラット副腎 移㥀つ実跧に於て Greep and Deane と全く同様つ見解をとつて扔り，Willams (1947) 221)等も被膜細胞が皮 質紐胞に再生增殖するという，所謂被膜細胞胚车説には否定的な見解を示している。乙れらの実験は，何れ も被膜下の皮質細胞があくまで皮質細胞の増殖源であるとの見解を示している.

さて私はこの実験に於て，各時期つ副腎皮質再生期に於て，特に被膜内の核分裂像に留意して観察したの であるが，明確な被膜内の核分裂像は Greep and Deane が述心゙ている如く認㧹なかつた。併し第 2 群の コルヒデン投与群に於ては，再生の極》て初期に多数の核分裂像を被膜内に捉えるてとか出来た（写真７）. しかしまた再生過程つ進んだ時期に於ては，再生皮質全般に百つてかえつて多数增加し，被膜内には反対 
に減少してくる事実を知つた。乙れは被膜細胞から皮質細胞の再生増殖の可能な点を想像せしめるもので， 更に皮質細胞自体も旺盛な增殖能力を示すものであるととが考えられる。また被膜内の核分裂像は，コルヒ チンを投与しない限り発見出来なかつたのは，被膜細胞の核分裂は非常に短い時間で終了するた妨に，普通 の観察では発見が出来なかつたためと思われる。 またコルヒチン自体か強い Stress として作用し，更に増 殖過程を扎し進め，核分裂像の出現を多くしたためかも知れない．

ての実験では被膜内の核分裂は特に再生の初期に極めて多く, 再生がある程度進めば再生紐胞自体が更に 增殖的役割を演ずるようである。即ち Enucleation の如き状態下に於ては，副腎皮質の如何なる個所（皮

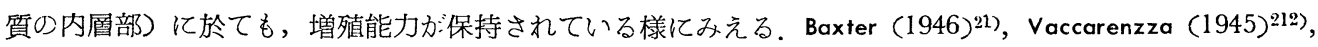

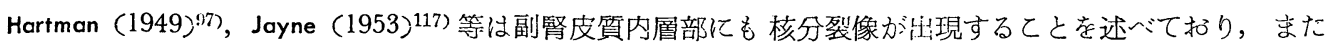
Baxter (1946):11) は網状帯にも核分裂の存在をみとめ, 乙の首が全く変性，崩壊首でないととを示すと述 ベている.またラットに ACTH を大量投与した場合には，網状带にも核分裂か泏現するものである

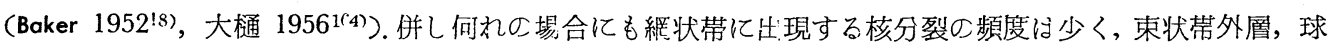
状帯に最も多く出現するととは確かで, 網状帯に核分裂が出現するととで escalator theory を決して否定す る理由にはならない，また副腎皮質細胞の増殖を単に核分裂の分布のみから判断するのは，当を得ないもの がある。核分裂の出現は動物種により，また年令によつても非常に差がある点が知られている (Blumenthal 1945) 8) $^{*}$ Zwemer 一派が述べている樣に, 被膜その他の fibroblast-like cell からの metamorphosis が副 督皮質紐胞す増生には極好て大き役割を占めているようである。特に Enucleation の際には，被膜から 多数の結合織様細胞か溹状に内方に侵入している像がみられ，乙れら細胞は被膜細胞と同栐に注目に值する 沂兒を呈している．更に被膜直下に於ては少型のクロマランの多い被膜細胞との中間形と思われる紐胞が注 鬥している，乙れらの細胞は Atkinson (1954)12)がマウス副腎皮質增殖の場合のべているA 細胞, 更に安藤

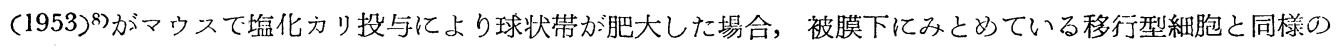

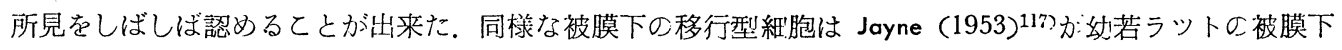

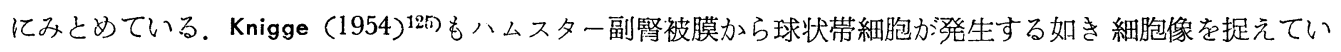

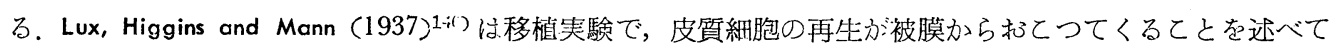
いる. 更に Baxter (1946) ${ }^{21)}$ は被膜下に同椂移行形細胞の存在をみとめ, 球状带細胞力澵しく紐胞を堌殖す るときには preglomerulosa cell の增加がみられると述べている. Enucleation の場合には，被膜内の被膜 腺腫の出現や皮質内結合織中の皮質細胞島き傍副婜を極めてしばしば認めるてとが出来る。乙れら細胞の組 織化学的所兒は Jayne $(1953)^{117}$ )が述べている如く, 再生皮質細胞と全く同樣であり, 結合織中に皮質芽細 胞があり，成熟して皮質細胞に移行したと思われる所見である. 被膜内と球状帯型の細胞島がみられるとと は，Williams (1945)20)も述べて招り，ラットでも老年になると皮質結節 (Yeakel 1947232)，Dribben and

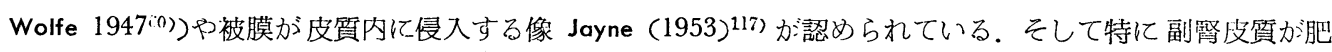

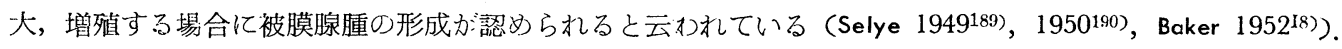
また Wolley, Fekete and Little (1940228)，1941299)，Wolley (1950)227) はJAX dba 系マウスで去勢後被膜 下に多数の核分裂像と結節性肥大が出現するてとを涊めている.

実験的に副腎不全に陥らしぬた状態に於ては，乙の種の仿副腎か溌生するものと考えられている. (Schour and Rogoff 1936) ${ }^{1-n}$. 傍副腎仙一般飞副腎不全の場合 coelomic mesothelium から増殖するもので, coelomic wall の細胞は active interrenala tissue 亿分化する潜在能力を有するものと考えられている(Mac Forland $1945^{147} ;$ ).

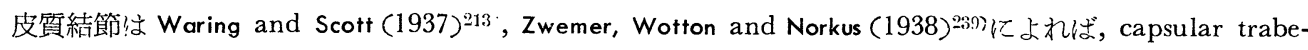
culae から形成されると考えられている。副腎 Enucleationの場合に，てれらの異所的皮質細胞增生のみら れるのは，特に増殖機転が activate された結果と考方られる。 Zwemer，Wotton and Norkus (1938)23:3)佊 質細胞凹芽細胞は被膜内の fibroblast-like の細胞で离り，この細胞から被膜下に於て皮質細胞に metamorphosis すると主張しているが，副珡 Enucleation の場合は，単に被膜下のみでなく，結合織内に於て異所 
的に堌殖する傾向が大きいと思われる。

Enucleation の際には，要約すると次図の如き増殖形式か存在するととか確められる。

第 1 図

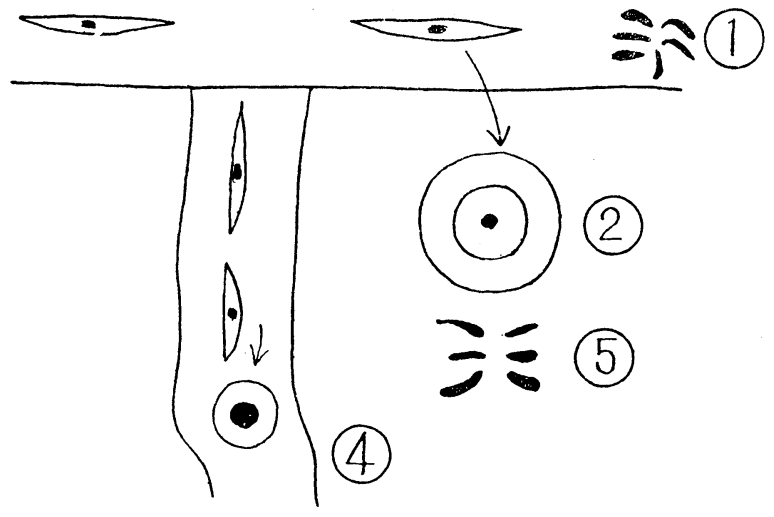

(1) 被膜内の増殖及び分化 (fibroblast 様細胞の分裂像）

(2) 被膜下に於ける metamorphosis

(3) 皮質細胞の核分裂

(4) 皮質原基が一旦皮質内に侵入し， そこで分化する形式

Enucleationの実験では，単にZwemer 等が述べている如き被膜下に於ける分化 のみではなく，更に多種多様の増殖形式 をもつものであつて，正常副腎に於ても てれら増殖形式が多分に存在するのでは ないかと思われる. Gruenwald and Konikov $(1944)^{91)}$ は被膜加分化した皮質細

胞か増殖するには多くの哺乳動物で，二つの機構が存在するととを述べている。一つは Zwemer (1936237), 1938239))等が述べている end-to-end junction of newly formed cords で, 他は apposition of a complete new layers から球状带細胞に移行する形式とである。また分泌皮質細胞の増殖には

(1) 球状帯と束状帯の間の核分裂

(2) 球状帯にたくわえられている細胞の動員

(3) 被膜にたくわえられている細胞办ら appositon による再生増殖 が考えられている.

Vaccarenzza (1945) ${ }^{239)}$ によれば，皮質細胞の増殖は移動ではなく, centripetatl proliferation であるとして いるが，少くとも Enucleation の際には両者がありうるととが考えられる。

Salmon and Zwemer (1941) ${ }^{17 n)}$ はトリパンブルー生体染色から, 皮質細胞が被膜加ら球状带細胞に escalate するに6日，被膜加ら東状带へは12日，網状带には20－30日要すると述べている，乙の晃解にはかなりの反 駁がみられはするが，副掔 Enucleation 後の再生過程は，乙の成績と略々一致した日数で風形成が行われ る点は，興味あるととつ思われる。

\section{皮睤機能の恢復}

一般に Enucleation の再生初期には，細胞内に殆んどリポイド顆粒か諗められない，乙れらの細胞は未 だ分泌活動を営まないと考うるよりは，むしろ分泌機能元進の状態のためにリポイドがないものと考えられ る. 何故ならば，再生初期の極く僅かの皮質細胞で，已に副筒不全を扎てさぬ量のホルモンか出されている からである. Hartman, Brownell and Knouff (1947)96)，Hartman (1949)(7)によれば, Enucleation の際少量の 皮賀組織か泟常以上のホルモン分泌を行うことを述べている。徒来より諸家により副腎皮質機能の組織化学 的な指標力洘えられて扣り，Dempsey (1948)等の多角的証明法が皮質機能判定に広く応用されて来た。 して皮質㙨能とリポイドとの関聯 (Deane and Seligman 1953\%0), Deane 等 19464\%), 1948\%2), 橘 1951208)), 重屈折性 (Weaver and Nelson 1943)214)，アスコルビン酸との関聯 (Sayers et al 19441:1), Sayers et al 194612), Knoff, Brown and Schneider 1941126), Dosne and Dalton 1941:99), Ludewig and Chanutin 1947143)), 才 スミウム酸との関聯 (Flexner and Grollman (1939)7氵) )が述べられている。また正常動物では Sudan, Schiff,

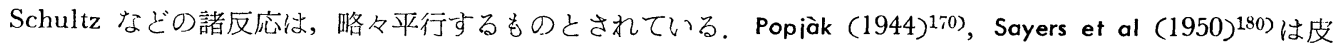
質にみられるコレステロールは，打そらくステロイドホルモンの storage form またはその前段階物質形成 《使われるものと考え, Weaver and Nelson (1943)214)は微細な重屈折物質のみを storage form とみなして いる、一般にリポイドは皮質機能攵進時にも低下時にも消失するととか知られている (Deane and Greep 
1946)46). そして Enucleation の際にみる無りポイド状態は, 前者即ち分泌か汛速て䋖胞内に蓄積するいと まのない状態と考えられる. Enucleation ラットの抵抗力は初めの 1 ～５日まで極めて弱く，ての事は第 3 群コルヒチン投与実験に於ても窮われる. 即ち1〜 5 日目のものはすべて, コルヒチンの毒性によつてた 扔れ，5 日以後のものはかなり抵抗があり，10日目のものは死亡しなかつた。 それ故 Stress に対する抵抗 性も, 皮質細胞が再生すると共に次第に恢復するものと考えられる。蓑えた副腎の再生か浣了した場合には噵 質がなくとも，副婜はインシュリン・ヒスタミン・寒冷に反応するてとか諗められている (Gordon 1950) ${ }^{82}$ ).

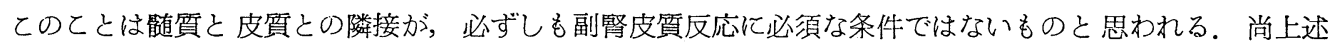
Thorn test では Enucleation 後25〜30日後に血中好酸球減少率は50\%以上となり，ての時期で初めて下垂 体副腎系方泟常に復するものと思われる. Greep and Deane (1949) ${ }^{(6)}$ は Enucleation 後32日後に於て，ア スコルビン酸が組織化学的に正常值に復するととを述べ, Gordon $(1950)^{\$_{2} 2}$ は化学的に同じく Enucleation 後32日後にアスコルビン酸は正常值より幾分高いが，一定值に復するととを述へている。また組織学的にみ ても1ケ月位で初めて皮質全首の完了がみられ，更に副腎重量の点からもての時期に於て，元の副腎皮質機 能状態に復したものと考えられる。乙の点 Thorn test がての時期に初めて陽性となるとととは，非常によ く合致する事実である，中尾 (1952) ${ }^{162)}$ は副腎 Enucleation により血圧は初め低下するが，束状帯の再生 により正常にもどるととを述べている。

一般に球状带細胞と束状带細胞とは二元的構成よりなり，前者は電解質代謝ホルモンを，後者は糖質代謝 ホルモンを分泌するものとされているが，もしそうであれば，Enucleation 後球状帯が出来上る時期には電 解質代謝ホルモン分泌機能のみが恢復し，束状带細胞が再生される時期に及んで糖質代謝ホンモン分泌が 恢復すべき䈏で，Enucleation の方法は副腎皮質の 機能局在性を分析するには極めて好都合である，倉田 (1952) $\left.{ }^{133}\right)$ は副腎 Enucleation 後 5 日以内に加里毒性試験は正常に恢復し，水中毒試験は10〜20日の間に至

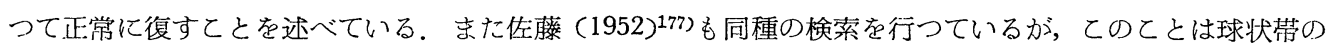
再生か浣了すれば，球状带から出される電解質代謝機能か洃復するものとみて好都合である．しかし氏は球 状帯から分泌されると云う塩類代謝と水代謝に関聯する副腎皮質ホルモンは，質的にか或いは量的に元性 質を異にするてとを暗示している。 また glucose 投与後の肝グリコーゲン沈着作用能は，30〜40日に恢復 するてとから，鉱質コルチコイドと糖質コルチコイドとの独立性を一応認めてよいと結諭している。また Greep and Deane (1949) ${ }^{86)}$ は Enucleation のラットに DOCA を投与して, 束状帯には何ら変化なくして, 球状帯の萎縮と, リポイドの消失を誋め, 二元論を認めしめるに好都合な結果を出している。併し, 他方 Brownell, Hariman and Reiman (1950) ${ }^{32}$ ) Enucleation 後 serum sodium の值を測定し, 術後数週間は正 常以下で，54日でも恢復しない点をむげている，そしててのてとは，再生された球状帯から出されるホルモ ンは全風が全く再生されるまで分泌されないのか，または二元論には誤りがあるためかも知れないと述べて いる. Enucleation 後の再生副緊皮質は一般に組織学的, 組織化学的にみて特に初期に於ては, 球状带と束

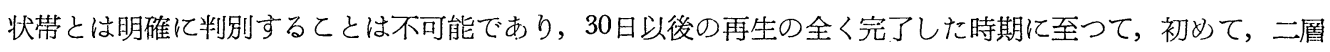
の判別が明確となつてくる. Willams (1947) ${ }^{221}$ は移植再生副腎に於ても, 球状帯と束状帯との明確な分離線 は認められないととを述へている。またか子る再生期に NaCl, KCl, DOCA (第 3 編に後述) を投与しても， 球状带には Deane, Shaw and Greep (1948) 占)が述べている如き, 明確な変化は惹起されなかつた。 Greep and Deane (1949) ${ }^{86)}$ が Enucleation ラットに DOCA を投与して, 球状帯に disuse atrophy を認めてい るが, てれは Enucleation 後1ケ月半のラットに1日 $2 \mathrm{mg}$ 1 ケ月間投与した場合の成績で, 再生が一応完 成した後の状態である。私も Enucleation 後 1 ケ月後に $\mathrm{NaCl}, \mathrm{KCl}$ 投与な行つた場合には, 正常ラット 副婜と同様に球状带に若干特異的な変化を認めた，以上の点より，再生初期には組織学的，組織化学的にも

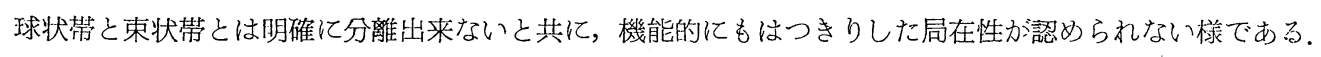
しかし再生が全く完成してから, 初めて外層部と内尿部の機能局在性が現われる樣に思われる。てれ等の点 は Deane 一派か漒く主張している皮質二元論には異論が存するもので, 球状帯細胞も束状帯細咆も本は同 一系統の細胞であるものと考えざるを得ない，また副督 Enucleationのときに特に興味ある事実は，皮質 
細胞の未だ極く僅かな再生期に，fat factor が正常以上に増加する点であり，てれは比較的少量の皮質成分 でも比較的大量の皮質ホルモンを分泌する能力があることを示すものとして注目に值する事実である (Hart-

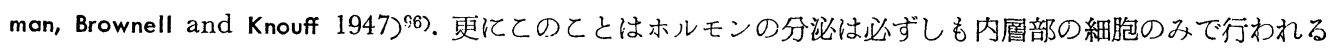
ものでないととを示すものである。 また gluconeogenetic factor の方は Enucleation 後 1 ケ月で最高とな

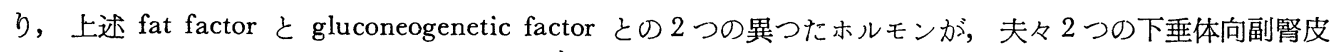
質刺㦸示ルモンによつて支配されているとと交すすのと考えられている (Brownell and Hartman 1948) ${ }^{31}$ ).

要するに Enucleation 後の再生期に於ける副腎皮質機能は正常の場合とはかなり異るもので，か〉る状 態から副腎皮質内外二層の分泌機能を分析するととば篮理なようである. 即ち小数の度質紐胞でも，かなり 高度の皮質機能代償力行われるものの如く考光られる. Greep and Deane (1949)86)も Enucleation 後1 ケ 月も経てば, 組織像の上でも，また機能的にも元の副腎皮質の状態にかえるものとしているが，一方 Ingle， Li and Evans $(1946)^{115)}$ は数ヶ月前に Enucleation を行つた老年ラットは大量の ACTH を每日投与しても， 極めて少いか，または全く反応しない事実をあげている。乙れらの点については，更に検索を要する点であ る.

\section{体重曲線}

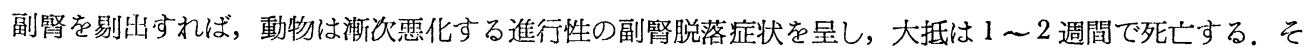
の致死原因は副腎皮質の脱落であつて，髄質でない点は多くの人々によつて主張されてきた。

副腎を雨侧共に剔出すれば，一般に体重は減少するが，てれは脱水によるものとされている (Hartman 1949) ${ }^{97}$. Enucleation の場合には, 殁んど体重の減少は認められず, 倉田 (1952)133) も正常発育曲線を示す ととを述べている。併も私の実験結果では, 雄ラットは雌ラットよりも体重の増加がや〉著明である。乙の 事実はかかる時期には皮質ホルモンの不均衡があり，雄の場合特に性ホルモンか関与しているためかも知れ ない.

\section{Enucleation 後の再生に及ぼす条件}

正常ラットでは一側副腎を剔出すれば，他側が代償性に肥大するととが知られている (Mac Kay and Mac Kay 1926148), Mac Kay and Polland 1931149), Carlson 193136), Swinyard and Bruner 1940:05), Tepperman, Engel and Long 1943209), Miller 1950153 ). 乙の場合組織学的に束状帯紐胞の肥大か顕著であるが, Miller (1950 ${ }^{153)}$ はマウスで, Swinyord and Bruner (1940)205)は大で球状帯も正常より広くなり：ミトコンドリアも増殖する 点，他のS Stress とは異るものである。 また Tobin (1939) 2103 は胎生シットの片側副腎剔出の場合も球状帯は ウか䡒加するものとしている。一般に一㑡副腎剔出による他側の代償性肥大は，下垂体剔出の場合には認妙 られず，やはり下垂体范介する肥大と考元られている(Tepperman, Engel and Long 1943209), Miller 1950153). Gemzell, van Dyke, Tobin and Evans (1951) ${ }^{80)}$ は両側副腎剔出を行えば，下垂体 ACTH の分必を促し，末 梢血 ACTH の量も堌加する, それで多分一側副腎剔出のときにも, 同様な ACTH の上昇を示すものであ ろうと述べている. Enucleation の初期には殆んど副婜剔出の状態に近いから, 大量の ACTH が分泌され るであろうことは想像に難くない. 鈴木 (1952)203)もかかる検索を Enucleation ラットの下垂体を検索して 述べている. 併し一側副婜を残存して扑けば, Enucleationの再生か藷しく抑制される. Ingle and Higgins

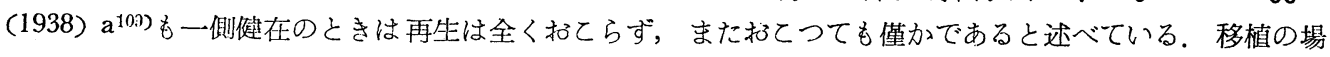
合も一側副腎が残存して招れば，再生は行われないととも知られている (Ingle and Higgins 1938 b Wyman 1928231))。乙れらの事実は Enucleation 副腎の再生を刺战するには，一側副腎剔出時に於ける他側 代償性肥大に要する ACTH よりも更に大量の ACTH の分泌が必要であろうと考えられるのである. Ingle and Higgins (1938) c $\mathrm{c}^{111}$ は再生速進過程《立垂体 Adrenocorticotrophic hormone によるもので, 一㑡健 在の場合にもサイロキシン等を投与すると, Enucleation 側つ球状帯 capsular remanent を刺㦸すると䢞 べている.一側健在の場合には, 組織学的に再生が悪く, 特に中心部には菱縮性の D細胞の出現を認めたの はやはり，ACTH の分泌か内㜿部細胞まで再生を遂行するには不充分な量であつたととを示すものと思わ れる。 
正常動物で一側副腎剔出を行えば，他側の球状帯も幾分肥大する。. Enucleation の際には，残存側副腎の 球状帯がかえつて萎縮している点は興味がある。

\section{第 5 章 要約}

1.副腎を被膜のみ残して Enucleation の処置を施しても，動物は何等副腎不全の徴を呈するてとなく， 体重増加も顕著である，被膜から再生した極少量の皮質細胞でも，充分生命維持に必須な皮質ホルモンを分 泌し生体を維持占るととが出来ると考えられる。

2.コルヒチンを投与するととによつて副腎 Enucleation 直後では, 被膜内に数多くの核分裂像を認め ることが出来た，更に日を経過すると共に，被膜内の核分裂像は少くなり，皮質全般に増加してくる，汃 る Enucleation の実験より，皮質細胞は明汃被膜細胞加ら増生する㯖実を知つた。

3. 尚副腎 Enucleation の㬰験では, 皮質紐胞は, (1) 被膜内の mitosis により, (2) 被膜紐胞の皮質細胞 への metamotphosis，(3) 皮質細胞の mitosis，(4) 被膜加ら結合織力波質内に進入し，その中の皮質原基办ら metamorphosis により増生する四つの増殖形式か認められた

4. Enucleation 後皮質細胞は周辽部から再生するが，30日位で凮形成が完成する。乙の初期に於ては球 状带と束状带との区別は不明瞭であり, か〉る再生期には, 球状带の塩類による特異的変化は認められなか つた. Thorn test は25〜30日目に陽性となり, 副腎皮質機能もとの時期に至つて, 略々完全に再生するもの と思われる. 即ち再生初期には，皮質機能の局在性は認められない様であり，全皮質が完成して後に，皮質 機能局在性力認められるようになるものと思われる。

5. Enucleation 後の再生過程には, 極めて大量の下垂体ホルモンを要するものと考えられる

第 2 編 副腎皮質の自律性

\section{第1章 緒言}

多くの動物では，副掔剔出によつて短期間の内に死亡するが，その支配中枢である下垂体剔出の場合には かえつて長期間生存し得る (Swann 1940)204)。乙れは下垂体缺除によつては, 副腎皮質ホルモンの内, 蛋白, 糖代謝によるホルモンの分泌か隌碍されるのみで, 副腎皮質の塩類・水調節ホルモンの分泌は障碍されない ためと説明甘られている (Ingle 194210i)，Swann 1940204)）．即ち下垂体は諸種内分泌腺の中枢として，各種 ホルモン分泌の調節に与るが，副腎皮質の塩類・水代謝ホルモン等生命維持に必要なホルモン分泌は下垂体 の支配を受けていないと思われるためである．組織学的検索の上から，副腎皮質機能がどの程度まで下垂体 に支配され，またどの程度までが下垂体の支配を受けていないかという点を知るてとは，甚だ重大な課題で はあるが, また非常に困難な研究でもある。 それは下垂体剔出にようて, 他のすべての内分泌㵴器も著しい 影響を蒙むるために，副腎のみに出現する変化を指摘するて.とは不可能に近いと考えられる．しかし実際に， 下垂体剔出実験によつても，副腎皮質に現われるかなり興味ある所見を㨆み得るのである.

諸種内分泌腺の中でも副㹂は多くの動物に於て, 特に下垂体の支配を強く受けているもので, 実験的に下 垂体剔出，または下垂体に広範な機能障碍を惹起せしめるが如き病変が存在する時には副腎皮質は極度に萎 縮走示す (Smith 1926! 9), 1930200), Collip 193340), Schaffer 1933184), Shumacker and Firor 1934196), White

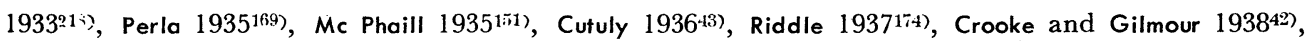
Meyer, Mellish and Kupperman 1939152), Miller and Riddle 193915), Deane and Greep 194646).

下垂体剔出による副腎の菱縮は皮質の菱縮に基くもので，娟質は殆んど変化を受けないものと云われてい

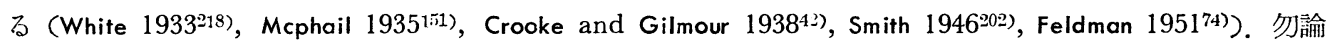
下垂体剔出後長期に亘れば，蹃質も幾分菱縮を示すが，皮質の変化は.ど著明ではない (Smith 1930200), Cutuly 1936'33), Reese and Moon 1938111)).

皮質の中でも特に束状帯, 網状帯の萎縮が著しく, てれに反して球状帯は佲んど正常, またはかえつて肥 
大するものと云われている (Crooke and Gilmour 193842), Houssay and Sammartino 1933103), Sarason 1943176), Deane and Greep 194646), Deane, Shaw and Greep 1948\%2), Greep and Deane 1949 (6), Schweizer and Long

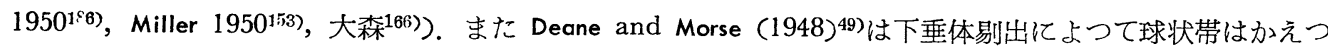
て厚くなり，アスコルビン酸も残存し，Evans and Li (1943) 年は球状帯のズダン顆粒，自働螢光性，重屈折 性は変化されず残存するてとを述べている，下垂体剔出によつて，束状帯からはアルカリ・フオスファタ 一ゼは消失するが，球状帯には残存するてとも知られている(Dempsey，Greep and Deane 1949) ${ }^{55}$. 下垂体 剔出時には，乙れら組織学的，組織化学的に束状帯は殆んど機能力停止する所見を呈するが，球状帯は少し も機能低下の像を現わされないのであつて，てのことは球状帯は少くとも副腎皮質束状帯や網状帯よりも下 垂体の支配を受ける影響が少いものと推定され得る。そして最近多くの人々により球状帯は塩類・水代謝と 密接な関聯がある如く実験的に立証されている (Orient-Keils, Robinson and Mc Collum 1937167), Miller and Riddle 1942155', Deane and Greep 194646), Greep and Deane 194755), Deane, Shaw and Greep 1948:52), Deane and Masson 195147), Badinez and Croxatto 194817), Nichols 1948164), Miller 1950153), Bacchus 195013), Bacchus 195114), Knowlton, Leob, Steegal and Stoerk 1949129), Jones 1950119), Bacchus, Heiffer and Altszuler 195215), Eichner 195365)). 実際下垂体剔出によつても副腎機能は全く停止するものではなく，か〉る萎縮副 腎でも幾分かホルモンを分泌すると云われる (Ingle 1942108), Hartman 194917). か〉る場合に，球状帯が份 泌機能を発揮しているものと考えるのが最も妥当である，またCortisone を投与した場合には，束状帯のみ か涹縮し，球状帯は殆んど変化しないととか知られて扣り，ての点は下垂体剔出の場合と同様である (Wells and Kendall 1940) $)^{216)}$.

てれらの実験的な根底の本に Deane 一派は副腎皮質二元論 (zonal theory) を主張するに到つたのである. 即ち束状帯は下垂体前葉 ACTH の支配の下に糖質コルチコイドを分泌し，球状帯は下垂体の支配を受ける ことなく，自律的に鉱質コルチコイドを分泌するという説を押し進めて行つた．球状带が鉱質コルチコイド を分必するという点は，央験的に Na 缺乏食の場合に束状帯には何等变化が打てらず，球状帯のみが䀧択的 に肥大し，機能元進像を呈し，またK缺乏食の時には逆にての風力撰択的に萎縮し，機能低下像を呈する. また鉱質ホルモンである DOCA を投与した場合には，球状帯のみか特異的に廃用性萎縮に扣ちいる事実は， ての風が鉱質コルチコイドを分必するてとを間接的に物語るものとされている。ての事実はその後も多くの 人々により追試実証され，一般に球状帯は血中 $\mathrm{Na} / \mathrm{K}$ 比によつて，そのホルモン分泌が自律的に調節せら れ, 従つて球状帯は血中 $\mathrm{Na} / \mathrm{K}$ 比の変動によつて, 或いは肥大, 或いは萎縮するものと考えられている (Deane, Shaw and Greep 1948:2), Badinez and Croxatto 194817), Nichols 1948164), Knowlton, Loeb, Steegal and Stoerk 1949128), Bacchus 195013)). また副腎剔出に上る動物の死因力塩類代謝失調 (Swann 1940204))であ るととを考え合すと，球状带は下垂体の支配を受けるととなく自律的に鉣質コルチコイドを分必するという 仮説は容易に納得出来よう．乙れらの関係は殆んどラットについての実験結果に基いているが，ラット以外 の動物でも，犬・モルモット・マウス等に於て，球状帯は下垂体に支配されず，自律的に機能を営むものと 考えられている (Houssay and Sammartino 1933103), Knowlton, Loeb, Stoerk and Seegal 1947127), Schweizer and Long 1950186)). また幼若ラツトについても，DOCA 怯球状帯を萎縮せしめるものであると述へている (Rennel 1952)173). そして Miller (1950) ${ }^{1537}$ は球状帯の刺㦸は, ACTH によつて打てら妨ととを述へている. 実際 ACTH はラットの電解質には，殆んど影響を及ぼさぬと云われている (Ingle, Li and Evans 1946"15), Ingle, Prestrud, Li and Evans 1947116), Bergner and Deane 194823)). それがために球状帯の自律説は, 多く の人々により強く認められている (Deane, Shaw and Greep 1948ラ⿱丶万), Nichols 1948164), Ducommum and Mach 194961), Daughaday and Mac Bryde 195045)). 併しての仮説には, 未だ賛否両論があつて激しい諭争が繰返さ れ,多くの学者 (Selye et al. 1950) ${ }^{195}$ ) 此の仮説を肯定するには未だ極めて慎重な態度を示している。また Deane 一派は，球状帯と束状带とは，構造・機能・origin 共に全く異つた二元的構成よりなるものと述心て いるが，ての主張に対しても強い反駁がある。即ち Stress または ACTH 投与時には束状带か肥大して機

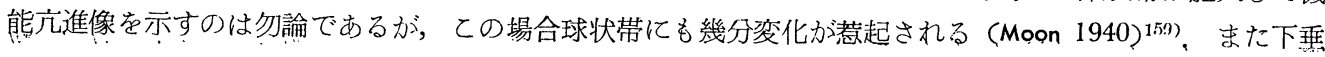


体剔出ラットに純粋なACTHを投与した場合, 球状帯に変化が扎てるてとも知られている(Wexler 1955) 特に AGTH を長期間投与した場合には，球状带は非常にうすくなり束状帯細胞の形態に似てくると云われ ている (Baker 1952) ${ }^{18)}$. これらの点は従来から説光られている escalator theory か適合するもののようで, 球状帯細胞も束状帯細胞も一元的な細胞で，外方から内方に移行する life history の一段階に過ぎないもの のようである. Baker $(1952)^{18)}$, Ingle (1942) $\left.{ }^{109}\right)$ 等によれば，乙れらの細胞を外首部から内層部に移行する 過程は，AGTH によつて行われるものとしているが，下垂体缺損時にはての増生過程が全く行われないと 述べている．併し，球状带細胞か諸家の述べている如き自律性格の強い細胞であるとすれば，乙てから更に 内層への移行は行われないとしても, 被膜から球状帯までの移行過程は当然遂行されるべき筈のものである. 併してれらの詳細な層形成過程機構の検索は, 従来何人も触れられずに来ている. 私は本編に於ては, 下垂 体がない状態下に於ても，球状带細胞のみは層形成を遂行し得るや否やの問題を，下垂体剔出ラットに副篮 Enucleationをを行い検索してみた。

\section{第 2 章 実験材料及び実験方法}

実験動物は雄・雌ラット体重150g前後のものを用いた。下垂体剔出術は慈恵中尾教室の方法により，エー テル麻醉の下で，気管枝側から行つた。，下垂体剔出後 3 日後に前編同様の操作の本で副腎 Enucleation を行 つた，尚此の場合は，第 1 編実験群に比し死亡率か㵔しく多く，特に動物の保温に留意し，副腎不全を防止 するために 3 日間 $1 \%$ 食塩水を $5 \mathrm{cc}$ 皮下に投与した。本編実験ラットの中，雄ラットは 12 匹中殆んど 5 〜 6 日内に死しし，1匹のみが生存し，雌ラットは20匹中 8 匹生存し得た。そのた少本編実験結果は主に雌ラッ トの成績である.

副腎 Enucleation の術式は特に慎重を期し，右側は剔出し，左側の Enucleation を行つた，副腎被膜下 の皮質細胞の殘存を極度に最小限䎲止めるため, Enucleation 時には, 被膜亦内を数回生理食塩水で洗い流 し, 殆んど被膜のみとなる様に努めた。 且つ 2 - 3 匹のラットは 3 日目に殺し, 組織学的に検索し, 殁んど 残存皮質細胞がないのを確めた。

動物仙副腎 Enucleation 後15日目に 5 匹，21日目に3 3 匹屠殺し，再生副腎は精確に torsion balance で 計測し，一部はブァン固定，一部は10\%中性ホルマリンで固定した。 ブアン固定のものはパラフイン切片に よりへマトキシリン・エオジン染色を, 中性ホルマリン固定のものは氷結切片 $(15 \mu)$ によ Sudan IV, Schultz, Schiff, 重屈折性, 及び Nile blue 染色を行つた。 また下垂体剔出の有無は屠殺時に綿密に確めた。

\section{第3章 実 験 結 果}

\section{再生副緊重量}

すべての例に於て再生副婜重量は著しく少さく, 15 日目のものは平均 $3 \mathrm{mg}, 21$ 日目のものも $3 \mathrm{mg}$ 前後に して，その間に殆んど重量の増加を認妙なかつた。 また15日目群の 1 例に於て，腎藏附近に粟粒大の傍副腎 の形成を認めた。

\section{組織学的所見}

15日目の副堅被膜仙著しく膨化して打り，币が著しく厚く，一般に被膜細胞は比較的数が多い。しかも被 膜の外㐿部之内層部とでは，明確に差があり，内層部に於て比较的細胞数が多い．被膜下にはかなりの巾の

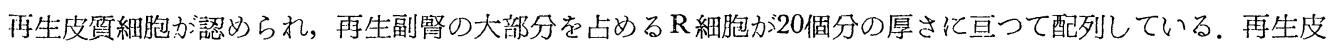
質紐胞つ大きさは幾分少さく, 被膜直下加ら一列に索状酒列する傾向を示し, 著しく密に存在している. てれらのR 細胞首の内側には，第 1 編に於て述べたと同様の極めて少数の $\mathrm{D}$ 細胞群，または結合織がみられ， 副緊の中心部を占邓ている，R 細胞は組織学的に二層を区別するととは出来ず，中心部の $\mathrm{D}$ 細胞群とははつ きり分劃されて抢り，移行症に相当する層は全く認められない， R 細胞は一般に Sudan IV 染色により， うすく濔漫性に染り，リポイド顆粒は極めて微細である。尚 Schiff, Schultz 重屈折性も略々同様な所見を 是するが, Sudanより Schiff 反応の方がかなり強く染つている。しかしR細胞の中でも処々に粗大顆粒を 
有する細胞が少数ではあるか認められる，D細胞はSudan IV 染色で粗大滴状に濃染し，また Schiff, Schultz 重屈折性もSudan IV 染色よりは弱いか陽性に染る。また被膜内に於ても一部 Sudan IV, Schiff 反 応か漒く俎大滴状に染るものか認められた。中心部の D細胞及び結合織中には黄色の色素力㵔しく多く認め られ，てれらの色素はSudan IV に染らなかつた，21日目群の副腎に於ても，15日目群と全く同様であり， その間に層形成の進捗したと思われる所見は認められなかつた。

\section{第 4 章 考案}

副粲皮質の層形成には下垂体前葉の ACTH が必須であつて，下垂体剔出時には風形成過程か行われない ことが Ingle and Higgins (1938 a) ${ }^{109 ;}$ ，Greep and Deane (1949)`6iにより述べられている。また副腎被膜 加ら皮質細胞に metamorphosis を行うためにも，更にまた皮質細胞の堌殖が行われるためにも ACTH が 必要であるととが述べられている(Baker 1952) ${ }^{18)}$ ．併し私の実験結果では，下垂体のない状態下に於ても被 膜から皮質細胞への metamorphosis 及び増殖がある程度行われることを示し，てのととは球状帯に相当す る皮質細胞は自律的に增殖しうる可能性を立証し得る。しかしか〉る状態下に於ては，更に内風の皮質細胞 への増殖は不可能であるととも分る。下垂体缺損時に出来上つた再生副腎は，下垂体剔出時の菱縮性副腎皮 質に極めてよく類似している，ての場合外層部に再生した皮質細胞は幾分束状配列の傾向を示すが，やはり 球状带細胞と思われる。 それは下垂体剔出時の萎縮性副腎皮質に於ても，球状帯紐胞は门か機分広くなり， 束状配列の傾向を示すものであり，乙の実験の場合に於けるR細胞と極めて類似した像を示す。それでしの 場合の R 細胞はやはり球状帯に属する細胞群と断定してよいと思う。一方中心部を占める D細胞は組織学的, 組織化学的にも下垂体剔出時にみられる萎縮性束状帯細胞に相当している樣に思われる. 唯細胞の配列の上 からは，か〉る再生皮質細胞は球状帯の細胞なのか，または束状帯の細胞なのかは断定することは出来ない (か〉る缺点は Dr. Laquerよりも個人的に指摘されている). 併し私はての二風の決め手となる他の根拠を 示し得るのである。 それは第 4 編の実験に詳述する如く，汃る動物に ACTH を連続投与すれれば，上述の 如き被膜下の $\mathrm{R}$ 細胞群の下に更に新しい一つの尿か形成され，てれが組織学，組織化学的に束状帯であると とが判明出来るのである. 即ち ACTH か没与されない場合には束状带細胞が出来ないてとを確めている.

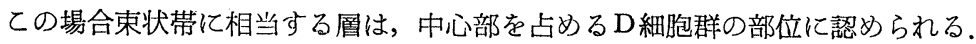

副腎の発育期に於ける下垂体の影響については，Domm and Leroy (1951) ${ }^{58)}$, Jost (1948) ${ }^{120}$ 怡生のラッ ト，ウサギの下垂体を decaptationにより剔出すると副腎の発育が遅延するととを述べている。かつる動物 副腎はすべての層の細胞と核がすさく，リポイドが少いと云われている.そして Kitchell and Wells(1952)124) は，外首部細胞を内層部細胞へ metamorphosis するのを遅延する結果であるとして扔り，ACTHがかつる 遅延を防ぐものと考えられている。汃る事実は副腎 Enucleation 後の再生期に於ける私の実験結果と極 めて類似した所兒である。

また副腎 Enucleation 後の皮筫細胞の再生機転は，副腎移植時の 皮質紐胞再生機転に非常によく似てい るものであるが，Enucleation の場合には手術的に皮質娟筫共に剔出するのであり，移植の場合は皮質髄質 の大部分が壊死に陥り，次で吸収され，その後皮質細胞か周辺部加ら新しく再生してくるてとに於て全く類 似儿ている。

併し Brenner (1954) $)^{30}$ は副堅移植時に皮質細胞は，次の如き段階を経て成熟皮質細胞に発育するととを述 べている. 即ち被膜に附着している球状带細胞は, 初めの1〜2 日は, (1) static glomerulosa cell に入る. ての時期にはかえつて細胞内にリポイドの韵積がみられるという. (2) 3〜6日にして transitional glomerulosa cell となり再生が初る：(3) 7〜10日にしてリポイド顆粒を含まない empty cortical cell に変り, (4) 11〜14日にして微細顆粒を含む granular cortical cell になり, (5) 16〜21日にして mature cortical cell が出来上るものとして扣り, Enucleation の際にも此と同様な再生過程を示すものとしている。7～10日目 に相当するリポイド顆粒の含まれない empty cortical cell は，已にホルモン分泌能力があると考えられて いる、乙れは細胞がホルモンの前段階物質を急速に放出するために，細胞内にりポイド滴を䈉積するいとま 
がないためと説明せられている(Brenner 1954) ${ }^{30)}$.

私の下垂体剔出副腎 Enucleation の実験時に再生する皮質細胞は，細胞内に殆んどSudan 顆粒を認めず， Schiff 反応が加なり高莈である状態で，上述の empty cortical cell 乃至は granular cortical cell の時期 に相当するものである. Komard and wyman (1951) ${ }^{132}$ ) 副腎移植後10日目 (empty cortical cell の時期)

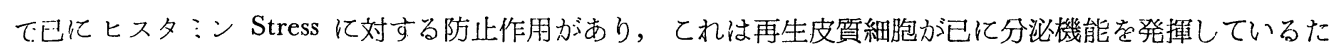
凶と考えられている。皇えれ故ての場合の Enucleation 再生副腎も組織像の上からは，已に分泌機能を発揮 しているものの如く考えられよう。しかもての場合つ再生皮質細胞仗下垂体のない状態下に於て自律的に再 生した球状帯細胞である点を考元合すと，乙れら再生皮質細胞は自律的に電解質・水代謝ホルモンを分泌す ることは想像に難くない.

DOCA 及び KCl の球状带に及ぼす影響は下垂体剔出ラットに於ても認阮られてとから, Deane 等

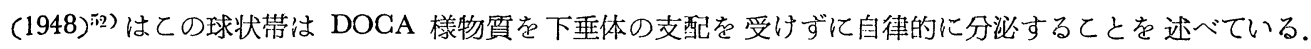
Stress や Estrogen による副粲皮質 (束状带) の肥大作用は下垂体 ACTH を介して行われるもので，てれ は下垂体剔出ラットに於ては，Stressや Estrogen によつて副腎皮質は全く反応しない点からも明かである

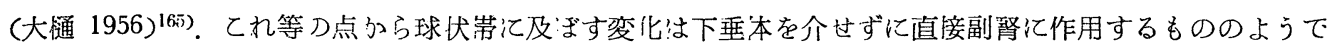
あり，また下垂体以外つ中介に上つて支配されているものとも考えられる.

併し一方, 副篎皮質つ增殖機䞑と分泌機能とを別個汇取り扱うべきものであり, 軽々しくか〉る結論を下 すことは出来ない，副腎皮質つ分泌機能を組織学的，組織化学的に云々するには常に皮質細胞つ大きさや， リポイド顆粒等つ分泌顆粒つ状態等つみ，を指漂としているのみで，あくまでてれは間接的な指標に過ざない.

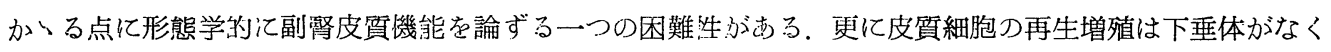
とも自律的汇行わ㣗得るが，機能的再生法下垂体がなくとも行われ得るや否やについても疑問がある。 ての 実験では確つに增殖つ面に於ては球状帯が下垂体とは独立的に再生しうるととを示し得るが，機能の面に於 ては，間接的にその自律的再生をうかがい知るのみで，ての点は更に他の方面からも寒付けを必要とする。

Sayers (1948) ${ }^{179)}$ は副穪皮質の自律性という点に関しては，副腎皮質のすべての面に於て全く否定的な見 解を示しているが，増殖つ面については明かに Sayers の主張は正しくないものと結論するととが出来る. 作しまた Sayers は AGTH を皮質ホルモンの前段階物質から皮質ステロールに変える一種の catalayst と 解歅し，ACTH が存在しない暘合でも皮質ステレイドの合成過程は遅くではあるが，全く停止するととは なく徐々に続けられると述べている，それ故副腎剔出の場合には，動物は短期間に死亡するが，下垂体剔出 の場合には長期間生存しうるものと説明している，汃る Sayers の見解よりすれば，再生皮質細胞は下垂 体がなくとも，皮質、テロイドを合成か河能な事も推察してよい筈である，ともあれ，ての実験結果の如く 下垂体剔!汇時に於ても，分泌譏能を有すると思わしめる如き皮質細胞つ再生增殖が自律的に行われるてとは， 副掔皮質細胞つ自律性という問題に新しい根拠を示し得るものと思う。

元来副督皮質周辺部つ球状带細胞は幼若な細胞と考元られて扔り，汃る細胞は中枢性の支配を受けるて となく自律的であるととは, Selye and Stone (1950) 195$)$ によつても想像されている. 哺乳動物以外にも Miller and Riddle (1943) ${ }^{(56)}$ は八トに於て，下垂体を剔!出すると皮質の中心部は萎縮するに反し，球状帯に 相当すると思われる周辺部細胞は萎縮しないてとを述べている。私の実験からも副腎皮質外圈部の細胞は束 状带細胞とは幾分異つた性格を有するてとが推測される。下垂体缺除時に於ても被膜から球状带細胞までの escalate は行われ得るが，球状帯以後つ紐胞えの進行は下垂体がない場合には行われないものと思われる.

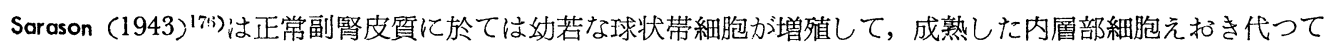
行くが，下垂体を剔出すれば未成熟のまま死滅するものと解している，か〉る見地からすれば，か〉る下垂

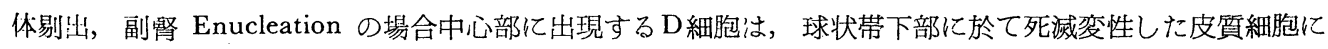
属するものと思われる，特にてれ等のD細胞内には，黄色の色素が多数認められるのか特徴である．Hoerr (1931)101:によれば人，モルモットの副腎網状帯にか〉る色素が多数みられるもので，細胞変性の場合出現 するものと解している，また Sarason (1943) ${ }^{176)}$ は下垂体剔出時には，束状带の内圈にか加る黄褐色の色素 
が多数出現するてとを述べている．またD細胞内には，pycnotic，extruded の核が多数出現している。一般 に下垂体剔出時には, 網状帯内にか〉る piknotic, extruded の核が多数出現するものと云われている (Smith 1930200), Crooke and Gilmour 193842), Sarason 1943176)). 色素の出現や，細胞，核の崩壊像等から推しても， てれ等 $\mathrm{D}$ 細胞は変性萎縮に陥つた細胞群であることか溶易に想像出来る。Hoerr (1931) ${ }^{101)}$ によれば，副腎皮 質内首部か湾性する場合には，次の二型の中何れかの型をとると述べている.

(1) cytolysis, chondroriolysis, Karyolysis, loss of lipoid and pigment

(2) shrinkage, homogenerization of the cytoplasm, chondrimegaly, pycnosis, retention or increased of lipoid and pigment.

このD細胞の場合にはむしろ後者に属する変性像に近い.

以上の如く，副腎皮質外層部の細胞は自律的で ACTH の支配を受けるととが少いものと思われるが，一 方ての部の細胞も AGTHにより,かなり変化すると云われる報告がある. 即ち下垂体剔出によつて球状帯も

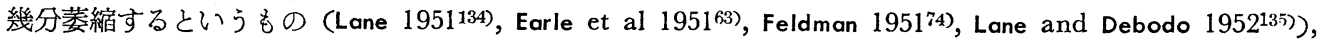
ACTH 投与によりラツト副堅球状帯が肥大するとと (Feldman 1951) 7t), Golgi 装置が肥大するとと (Reese and Moon 1938)171), ACTH によりマウス副腎球状带のリポイドか湾化するとと (Jones 1949) 118$)$ 等である。 また胎生ラットは ACTH によつて, 束状帯は勿論球状帯も肥大すると云われている (Kitchell and Wells

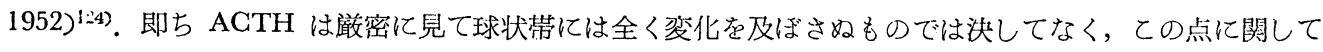
は第 4 編に败めて検討している。般に球状帯は下垂体の支配を受けないというのと，下垂体の支配ふなく とも自律的に増殖し機能を果すというのとでは, 笽密に区別すべきであつて, 私の実験では後者か泟しい々 思われる. 球状帯は明かに ACTH によつても変化するものであつて, 球状帯には常に自律性格+ACTH

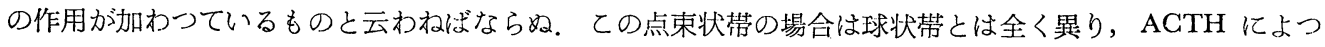
て初めて增殖し，機能を発揮する様に思われる。

人の場合に於ては，束状帯と球状帯との態度を検索するととは一圆困難であり，また複雑でもある。人の 場合には，ACTH によつて糖質代謝のみなく sodium retention の礼てるてとが知られている (Forsham,

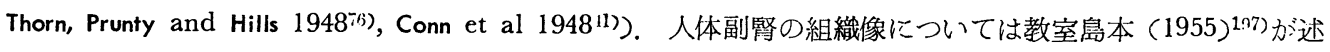
べている如く，諸種の因子の介入によりラットに於けるほど各層の反応態度は明確でなく，特に慢性疾愚の 場合には球状帯にも変化がみられるてとが多いと云われる。 また人体に於ては, 動物実験に於て観祭出来る

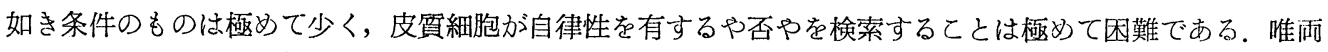
眼融合児の場合には，しばしば下垂体の缺除するてとが報告されている. Edmonds (1950) ては，副腎皮質細胞の発育は極めて遅延して扔り，皮質は非常にうすいと述へている。併しての皮質細胞は， 下垂体がなくとも自律的に出来上つたもの汃，または母体のAGTH が胎盤を介して胎児の副堅層形成江守 つたものか，現今では之を判定する手段に缺けている。 また最近胎盤内には ACTH が含まれる点が知られ

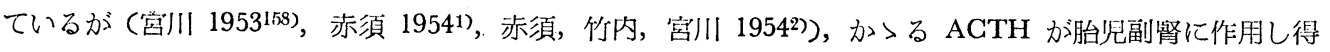
るととも考えられる.

\section{第 5 章 要約}

1. 下垂体剔出時に於ても, 球状帯細胞は副腎被膜汃再生され得る。

2.か力る再生副腎皮質細胞は微細な Sudan 顆粒, Schiff, Schultz 陽性顆粒を有し, 重屈折性榢性に乙 て，自律的に分泌機能を有するととも想像出来る.

3. 下垂体剔出時に於ては，束状带細胞の再生は行われない。 
第 3 編 副腎皮質細胞增殖に反ぼす各種ホルモンの影響

\section{第1章 緒言}

副堅皮質機能は下垂体前葉 ACTH の支配を受けているととは，今日明かな事実となつているが，副腎皮 質細胞つ堌殖は如何なるホルモンによつて支配されているであろうか. Greep and Deane $(1949)^{85)}$ 及び Ingle $(1938 \text { a })^{109}$ は, 下垂体 ACTH か洅生増殖を促進するものとしている. 従つて, 下垂体 ACTH の分 䎵を元進せしめる如きStressやホルモン投与は，また副腎皮質の再生を促進するように考えられている．即 ちサイロキシンや四塩化炭素は下垂体 ACTH の分必を穴める結果, 副腎皮質機能を元進せしめるが, 副腎 Enucleation 後の再生過程倡著しく促進的作用するととか知られている (Ingle and Higgins $\left.1938 \mathrm{c}^{111}\right)$ ). また Cortin の経口投与は副腎皮質機能を低下せしめるが，Enucleation 後の再生過程をも著しく抑制す るととか知られている (Ingle and Higgins $1938 \mathrm{a}^{103)}$, Higgins and Ingle 193898). か〉る点から正常副腎皮 質を肥大せしめる如き要因依, 副腎Enucleation の再生にも促進的に働くてとが想像されている (Ingle and Higgins $\left.1938 \mathrm{c}^{111)}\right)$. 即ち生体の皮質ホルモン要求を必要とする如き条件が，副腎皮質細胞の再生を促進せ しむる結果となるものの様である。併しまた一方副㹂皮質細胞の増殖には ACTH 以外のホルモンによつて も影響を受けているのではないかという疑間もある。併しか〉る検索は，従来殆んど行われて打らず, ACTH のみか㨽繁皮質細胞に影響を及ぼす唯一のホルモンの如く固く信じられてきている。 それで私は副 腎皮質の機能と增殖との二面から，ての問題を検索してみた。

副腎皮質機能に関しては，従来から下垂体 ACTHによつて強く支配されているととは周知の事実である が，各種ホルモン環境によつても大きく修飾を受けている．森教授 (1955) ${ }^{160)}$ はつとに内分泌自律神経環境 説を説えられ，個体力恒常性を維持するためには，絶えず内分泌自律神経相互間の緊密な協調の必要性を主 張せられている.また諸種ホルモン投与環境下に於けるる副腎皮質機能の検索については, 教室大樋 (1956) ${ }^{165)}$ が詳述して打り, 私は主として諸種ホルモン投与環境下に於ける副腎皮質の増殖の点に主眼を扣いて検索し てみた。

一般に下垂体前葉から出される ACTH は，その慓的藏器である副腎皮質のホルモンの血中濃度により自 已調節が行われているもので，とのととはすべての内分泌腺と下垂体前葉 trophic hormone との関聯に於 て共通的な原則である (Greep and Jones 1950 7)，Sayers 195010)．，即ち副腎皮質の著しい萎縮は大量の副 紧皮質ホルモンの投与により蕉起されるが，乙れい副腎皮質ホルモンが下垂体前葉に作用して ACTH の分 泌を抑制する結果と考えられている (Ingle and Kendall 1937114), Ingle, Higgins and Kendall 1938113), Ingle 1939106), Wells and Kendall 1940?16), Sarason 1943176), Antopol 195010), Sayers and Sayers 1947178) 副腎皮 䫓ホルモン投与に占る ACTH の分泌抑制作用は Stress の際にも認められ，予め副腎皮質ホルモンを投与 するととによつて，Stress によつて惹起する副腎皮質肥大やアスコルビン酸の変動が防止されると述べられ ている (Long $1947 \mathrm{a}^{141)}$, Long $1947 \mathrm{~b}^{142}$ ), Ingle 1938105), Sayers 1948179).

ステロイドホルモンの中でも Folliculoid は副腎皮質の著しい肥大と機能六進像を䓯起するが，乙れは下 垂体 ACTH を介して打てる変化と考えられている (Allen and Bern 19426), Selye and Stone 1950195), 大 樋 1956165)，土居 発表予定). このととは下垂体剔出動物に Folliculoid を投与しても，副腎皮質は何等肥

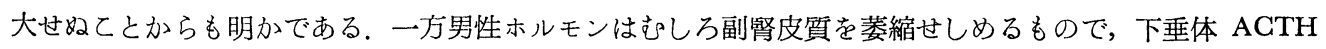
の分泌機能を抑制するためによると考えられている (Selye 1949189), 1950190`).

併し Testoid の作用には，下垂体を介过ずに直接副腎皮質に作用する機序も知られて招り，Follculoid と はちがつて特異的なホルモンに属する。私は Testoid のかつる特異的な面を, 副腎 Enucleation 後の再生

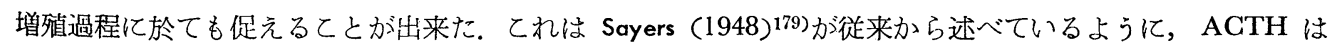
副腎皮質の機能並びに増殖つすべてを司る唯一の因子という主張には，同意出来好点でもある。また Sayers

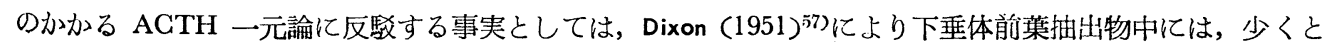


も2つの因子が存在するという報告である。即ち 1 つはむしろ副腎皮質重量增加作用があり，1つはアスコ ルピン酸减少作用か強く，前者は打そらく成長ホルモンと考えられている，成長ホルモンについても，副鞙

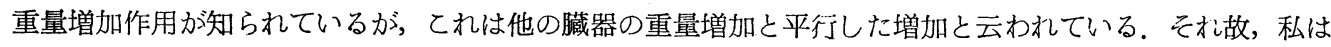
他の藏器重量も比較しつつ成長ホルモンの作用を検索した。

\section{第 2 章 実験材料及び実験方法}

実験動物はすべて100〜130gの雌雄ラットを使用した．副腎 Enucleation の方法は，第 1 編と同様で，右 側副腎は剔出し，左側副腎の Enucleation を行つた。動物は11群に分ち，下記の如き各種ホルモン投与及 び去勢を行つた。

第 1 群 副腎 Enucleation 無投与 (対照)

第 2 群 副腎 Enucleation + ACTH

第 3 群 副霜 Enucleation+成長ホルモン

第 4 群 副腎 Enucleation+Cortisone

第 5 群 副腎 Enucleation +DOCA

第 6 群 副㿡 Enucleation+Estradiol

第 7 群 副腎 Enucleation + Testosterone propionate

第 8 群 副腎 Enucleation + MAD

第 9 群 副堅 Enucleation + Progesterone

第10群 副㛑 Enucleation + Cortisone+ Test. prop.

第11群 去勢ラット副腎 Enucleation

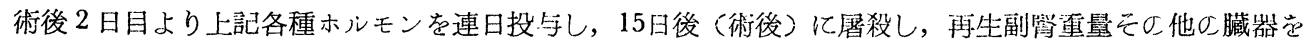
計測し，ブアン固定，一部は10\%中性ホルマリン固定を施し，へマトキシリン・エオジン染色及び各種脂肪 染色を行つた。

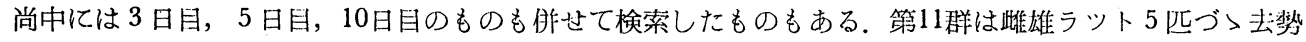
を行い，７日後に副筒 Enucleation を行い，更に15日後に屠殺した.

\section{第3章 実、験 結 果}

\section{再生副腎重量}

各種ホルモン投与ララツトの再生副腎重量は第 5 表及び第 6 表に示す如くである。ACTH，成長ホルモン， Testosterone propionate 及び MAD 投与群が，特再生副督重量が大きい，一方 Cortisone 投与群は下垂 体剔出群と同程度で, 再生副歓重量は最も少ない，DOCA は殆んど Cortisone にみる如き抑制作用は認め られなかつた，尚成長ホルモンには著しい再生促進作用がみられるが，すべて臟器重量を増大せしめる一部

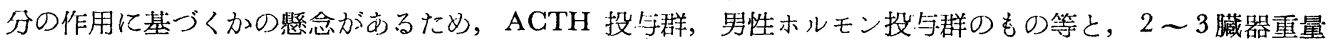
の比較を表示した。成長示ルモン投与群はての実験では, 他の藏器上りも副腎の再生に特に強い作用のある 点がわかる。

\section{体重曲線}

第7表に示した如くである。.

Testoid (Testosterone propionate, M.A.D.) 投与群结雌雄共体重は著しく増加し，一方 Cortisone 投与群 は著明な減退がるられた。 また Testosterone propionate と Cortisone とを併用した例に於ては，体重曲線 は雨者の中間位を占めた。 その他 DOCA 投与時にかなり体重の增加がみられた。

生塔ホルモンは体重の增加が特に著明であのた。

\section{組織学的, 組織化学的所見}

第 1 群 副堅 Enucleation 対照群（無投与） 


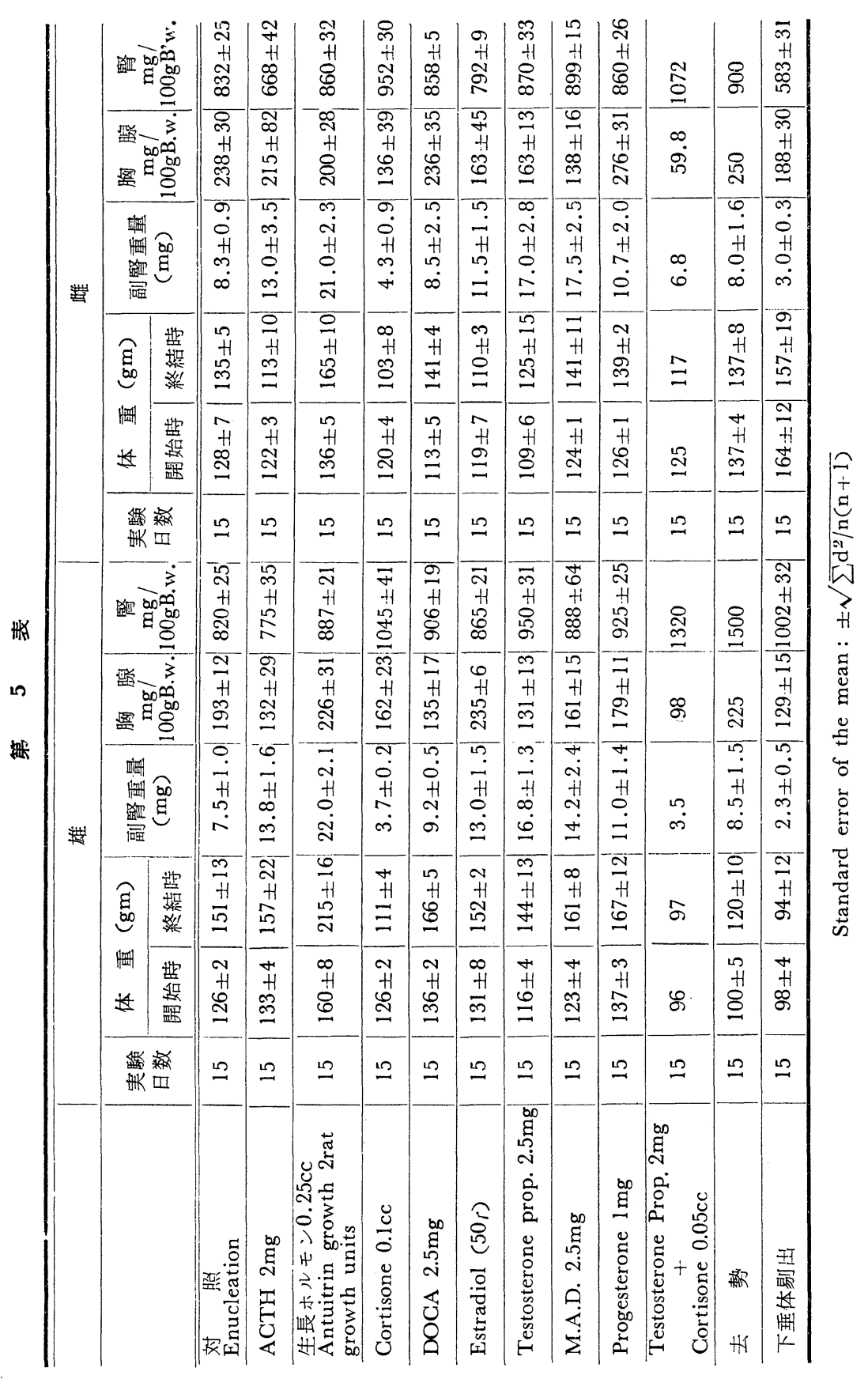

との成續は既に第 1 編に於て述べている.

第 2 群 副腎 Enucleation $+\mathrm{ACTH}$ 投与

副堅皮質細胞の再生は極めて良好であり, 被膜は符 1 群対照（第 1 編に於て詳述）に比して，著しく薄く

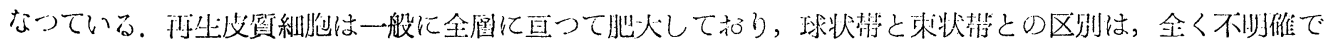


第 6 表 各種ホルモンの副腎再生に及ぼす影響 (重量mg15日間)

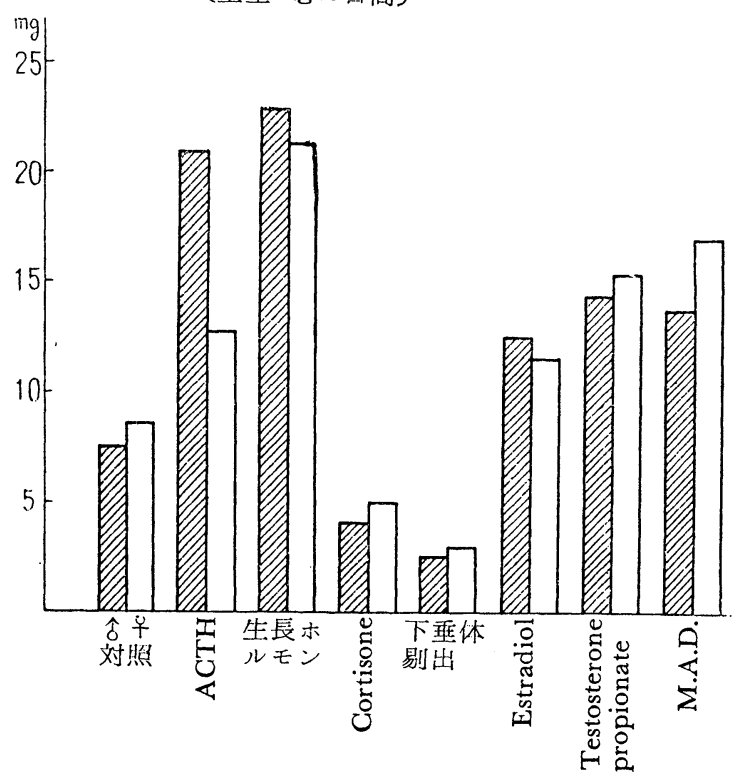

体重

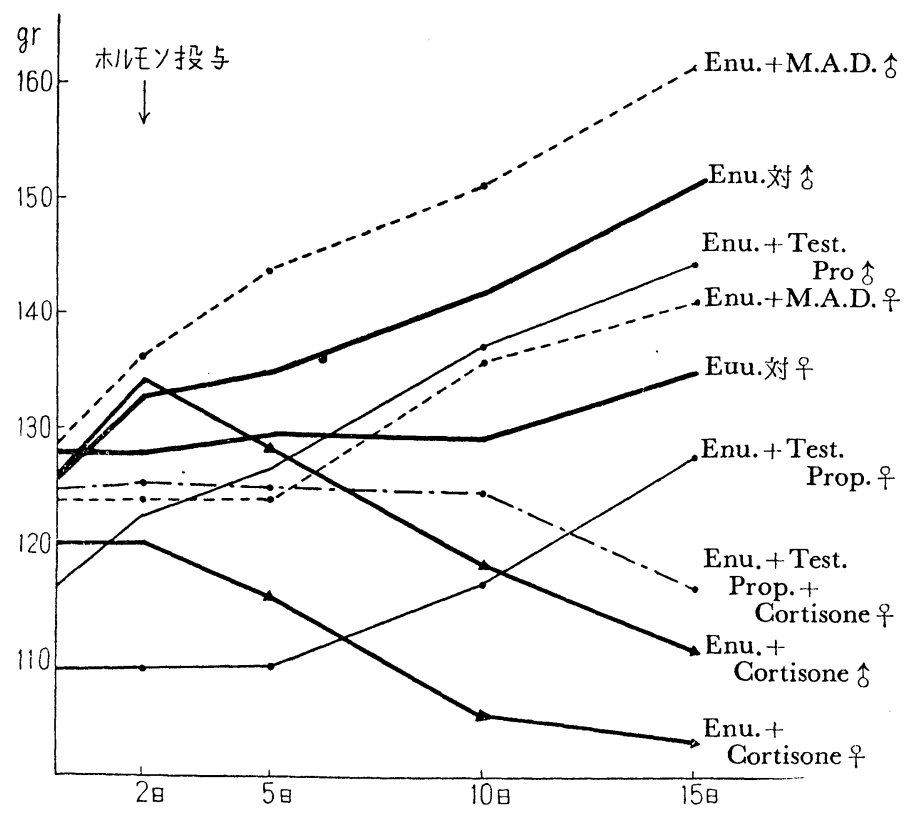

ある。しかも束状带に相当する個所は，加 なりの細胞変性像がるられ，核崩壊及び fibrinoid 変性，顆粒状変性に陥つた細胞 か認められる。雄, 雌ラット何れも同様な 所見を呈しているが，雌ラットに於ては， 特に細胞の変性の極めて高度のものがあり， 広範囲に顆粒状変性に陥つた細胞群內涊め られた。核分裂像は全皮質圆に亘り，且つ 中心部の皮質細胞にも多数泏現していた。

一般に対照群に認められる如き被膜からの 結合織成分の准入は㱠んど認》ず，中心部 には僅かの結合織か淮入しているに過ぎな い.また中心部の堎死物質も殆んど吸収さ れている。綃状带部心血管腔力渚しく開大 し，高度の立血像を示している。

組織化学的に，てれらのR細胞は殆んど Sudan IV 染色で陰性であり, 結合織中に は若干の Sudan 顆粒を認めるに過ぎない. Schiff 反応, Schultz 反応も Sndan IV 染色と略々同様で あるが，中心部の結合織内に は粗大顆粒が Sudan よりも や〉弱く染つていた。

\section{第3 群 生長ホルモン}

副腎皮質細胞の再生は極》 て良好であり，外層部の再生 紐胞は, 粗大空胞方多数出現 し蜂窩状を呈している。雄ラ ツトに於ては外層部細胞力㵔 しく肥大しているに反し，束 状带中層以下の細胞は非常に 小さく, 細胞索が著しく哆開 している.しかもてれ等の細 胞は, 細長で一部 Fibroblasten 様の外見を呈しているも のがみられた。併し細胞の変 性像や核崩壊像は殆んど涩》 なかつた。一般に被膜結合織 は非常にうすくなり，被膜力

ら信人するる結合織，中心部を占める結合織も殆んど認めなかつた。雌ラットでは内層部細胞は著しく肥大し て抢り，且つ核も大きく雄の場合とは全く所見を異にしていた。一般に R 紐胞の胞体は灯塩基性で，細胞内 には殆んど微細顆立を認めなかつた。

組䄉化学的にR 細胞は何れる Sudan, Schiff, Schultz 重屈折性が全く陰性であつた。 


\section{第 4 群 副堅 Enucleation+Cortisone}

再生副腎皮質仙極河て小さく，何れも被膜下の皮質細胞恼比較的再生過程も良好であるが，内層部は殆ん

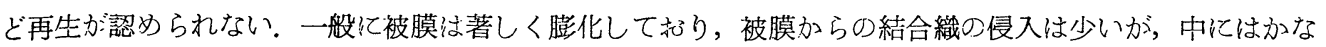
り多数侵入せるものがあうた。 てれらの被膜成分か溡に球状帯と束状带との間に侵入し, 結合織の帯として, 再生皮質を分離しているものも見られた。雌ラットに於ても, 再生皮質細胞は著しく萎縮性であり, 外層部細 胞も比較的菱縮性であつた。 また細胞内には，かなり粗大な空胞形成があり，海綿状を呈し，特に fibrinoid

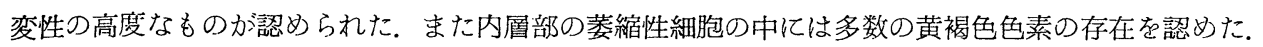

組織化学的には, 中心部つD 細胞群は Sudan で強く染り, 顆粒も粗大であるが, 周辺部紐胞は比輘的微 細顆粒状に染る. Schiff, Schultz 反応も Sudan よりはうすいがかなりよく染つていた。

\section{第 $\mathbf{5}$ 群 副㹂 Enucieation+DOCA}

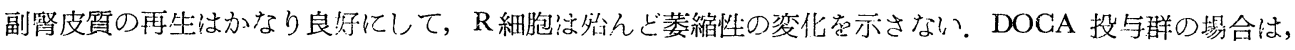
他つ群化比し被膜腺腫形成が著しく著明にみられ，被膜腺腫洼特に被膜部に数㑑出現しているものが多い． また被膜腺腫つ細胞虻略々 $\mathrm{R}$ 細胞と同様の所兒を呈し, 明細胞と暗細胞との区別か明確である。また fibrinoid 変性及びコロイド体形成のかなり認》られた例があつた。 内首部細胞も比較的よく再生され，亦なり

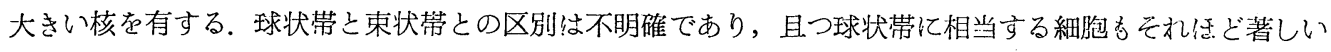

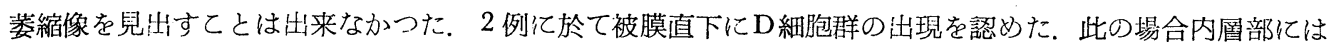
かつるD細胞群の出現なく, 被膜下にD細胞群方認妨られたのが特異的であつた。

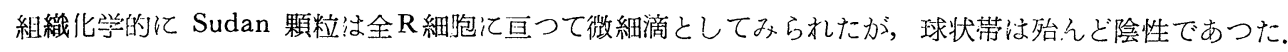

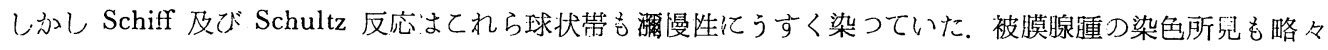
同様である。被膜下のD細胞揃仗此等染色で粗大滴状汇染つている。また中心部の結合織中にも Sudan 陽 性顆粒を認衿。

\section{第 6 群 副腎 Enucleation+Estradiol}

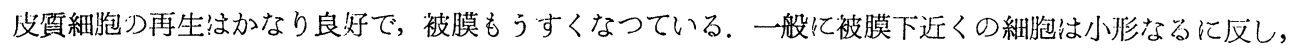
内厢部細胞绀著しく大きく，また著明な変性像がうかがわれた。しかし球状帯と束状帯との区別は極めて不 分明である。

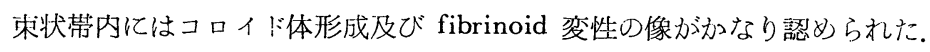

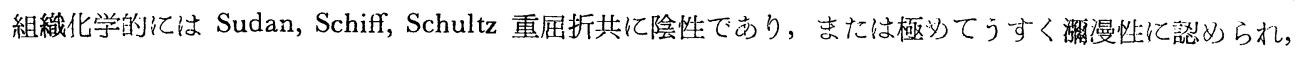
中心部の結合織中にわずわに粗大滴か諗められたに過ざなかつた。

\section{第 7 群 副腎 Enucleation +Testosterone propionate}

副督仙極》て大きく，皮質細胞つ再生は極めて良好である。きた結合織增生が著しく，被膜汃ら侵入せる もの及び，中心部の結合織仙極好て多く，また被膜側加ら trabeculae の進入も著明であつた。また部 に於ては結合織つ掖死物質を厚く取りまいている像があられた。被膜下には小型心增殖性細胞が多く, 且つ

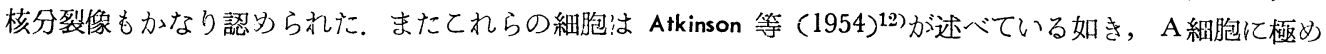
て類似している。被膜下刀ある個所门於ては明わ被膜細胞と皮質細胞との移行細胞と思われる細胞力諗》

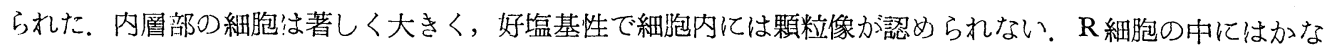
り多くの fibrinoid 変性及びョロイド形成か認》られる。 また脂肪細胞化生と思われる空胞細胞が少数出現 していた，皮質の外首部細胞は胞体は一般に蜂樂織状である。

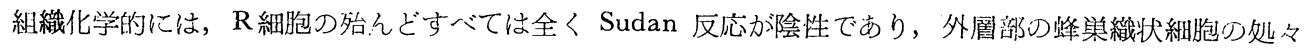

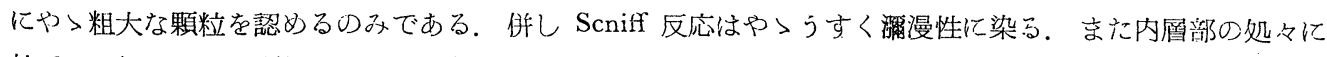
於てや〉粗大な滴状顆粒が極》て少数認められるに過ざない.

\section{第 8 群 副腎 Enucleation + MAD}

第 7 群はど再生は良好ではないが，対照群に比ずかなりの再生促進像か誌められる。被膜は著しく増生

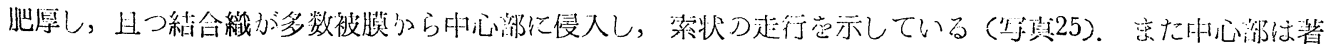


しく増生した結合織でらめられ，乙れら結合織細胞は細長の形態を示めしている．周辺部の皮質細胞は比輘 的海綿状檴造を示し，内粕部細胞!さ胞体が全く緻密で好塩基性である。むた被膜直下はかなりの細胞増殖像 が浔引られて，特て術後 5 日目の標本に於ては，核分裂像が多く，皮質細胞と被膜細胞との区別の不明確な中 間形細胞の出現が認められた。またある標本に於ては增生せる結合織中に 2 〜個の皮質細胞力混入してい る像が㤮められた。

組織化学的には Testosterone propionate 投与群と同様で， R細胞は Sudan IV で帉んど陰性である。

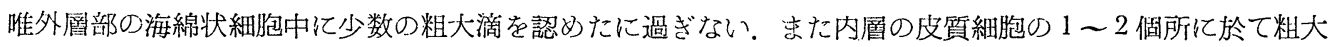
鮯状䫍粒を認妨たが，乙れは脂肪細胞化生によるものと考えられた。

結合蟣及び被膜内に混入せる皮質細胞も全く同様な所胃を星する. Schiff 反応は Sudan よりや〉つよく diffuse に染るが，略々 Sudan 染色と同様である。

\section{第 9 群 副腎 Enucleation+Progesterone}

再生はかなり抑制され，且つ高庶の変性像ぶみられ，皮質細胞中には細胞の崩壊及び fibrinoid 変性，コ ロイド体形成が認められる， R 細胞は全体的に萎縮性であるが，特に $\mathrm{D}$ 細胞の出現は認めなかつた。外層部 細胞は前群と同様比較的海綿状棈造の細胞が多い.

組織化学的には Sudan 染色で全圈の細胞はや〉粗大で，組織化学的には球状帯と束状帯との区別も略々 明瞭である. Schiff 及び Schultz 反応は Sudan IV 亿略々同様.

\section{第10群 副腎 Enuclearion ラツトに Cortisone と Testosterone propionate の併用投与}

Testosterone propionate 単独投与に比し，再生はそれはど顕著ではない。一般に皮質細胞は小さく萎縮 性である。また中心部にはD細胞群を認めた。

\section{第11群 去勢+副腎 Enucleation}

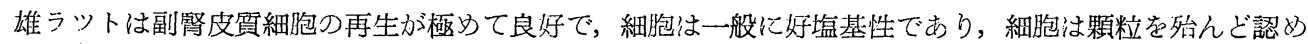
ない. 中心部には充血がかなり高度である。

雌ラットの昜合は雄ほど再生が著明でなく，細胞も萎縮性である．外層部の細胞は比較的再生が良好であ るが，中心部にはD細胞群が出現している。乙れらのD細胞群は Sudan, Schiff, Schultz 反応で粗大榈状に

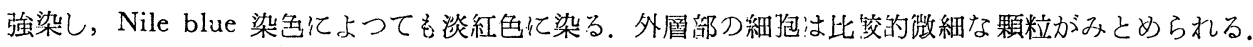

\section{第4 章 考案}

私の奌駼では，上述の如く副梷 Enucleation 後の再生増殖に対して ACTH・生長ホルモン・男性ホルモ ンなどに著しい促進作朋ぶみられた。乙れ等の哥実から AGTH 以外に，生長亦ルモン及び男性ホルモンが

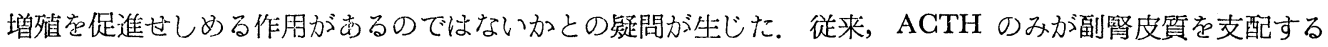
唯一のホルモンであるとの見解が多い.

Sayers $(1948)^{179}$ そよれば

(1) 現在唯一の AGTH が取り出されているに過ぎない.

(2) 今日分離されている純粋な ACTH は副腎皮質の大さ・非態・コレステロール及びァスコルビン酸筑 のすべての変化を萑起する.

(3) 純粋な ACTH は下垂体剔出動物の副餐の大きさ，構造を共に正常までに保持する.

(4) C 11 oxygenated steroid も desoxycorticosterone と共に下垂体 ACTH の分泌を抑制する.

(5)今日分離純化されている ACTH は，副腎皮質の Corticoid 及び性ホルモン耐者の分泌を刺㦸する. Sayers はこれらの理由加ら，AGTH は全副腎皮質に対して tropic であるとの主張を示している：そし

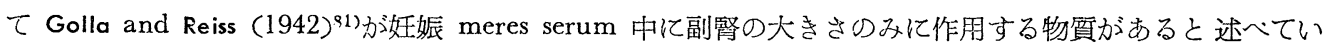
る点は，単に血中の AGTH を証明しているに過ぎないと反駁している。ACTH 投与時には副腎皮質は肥 大し機能厅進像を苾起することは疑のない点であつて，下垂体剔出動物でも ACTH 投与により副腎皮質が

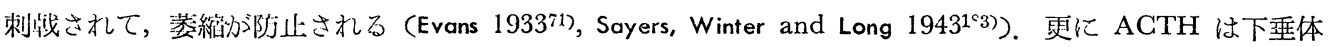


剔出動物の副腎の大きさ，組織像を保つのみでなく肥大を打てすてとも知られている (Reese and Moon 1938) ${ }^{171)}$.

種々の Stress により exogen に ACTH の分泌を促進せしめた場合にも，同様に副腎は肥大するととが 多くの実験によつて知られている (Selye 1937187), Ingle 1938107), Engel, Winton and Long 194367); Sayers,

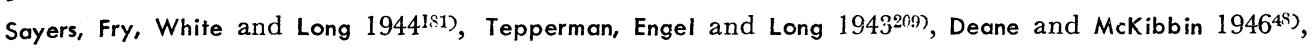
Sayers et al 1946182), Sayers and Sayers 1948179), Dugal and Therien 194962). そして Li, Evans and Simpson (1943) ${ }^{140)}$ は副腎重量は投与した AGTH の量て比例して肥大することを述べている. Folliculoid も副 督皮質の著しい肥大と，機能充進像を来すが，下垂体 ACTH 危介する变化とされている (Selye and Stone 1940) ${ }^{195)}$. 副腎皮質 Enucleation 後の再生には, ACTH も Folliculoid も促進的に作用し，乙れは ACTH 自体が再生增殖促進の本態と考えれば納得出来る. Ingle and Higgins (1938c c $)^{111)}$, Higgins and ingle (1938) $)^{8}$ はサイロキシンも四塩化炭素吸入も，共副筒再生現象を著しく促進することを述べているが，結 局てれらの要因は Stressot として下垂体 ACTH の分泌を克進せしめる結果認められると考えられる (Ingle and Higgins $1938 \mathrm{c})^{111)}$.

てれらの結果のみから判断すれば，副婜皮質の再生增殖機転もACTH 投与，またはACTH の分泌を充 わる如き要因によつて促進せられると考えられる。併し一氺，ての実験加ら男性ホルモン並びに成長ホルモ ン投与によつても，再生が著しく促進されるととがわかつた。一般に Testoid は副婜皮質に対して抑制的に 作用し，乙れは下垂体 ACTH 分泌機能を打さえるために打てる現象とみられている (Selye 1949) ${ }^{1999}$.

汃〉る抑制的作用を有する Testoid が Enucleation 後の再生には促進的に作用する点は，全く意外な綡 果であつて，てれはかつる Enucleation の際には TestoidもACTH 分泌充進作用へ転換するのか，また

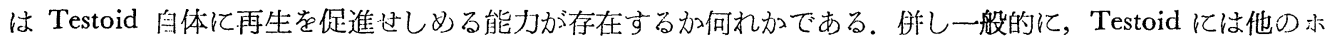
ルモンとは全く異つた副腎皮質に及ぼす特異的な作用が他の多くの実験加ら認められている. 即ち正常動物 に Testoid を投与した場合には副腎皮質萎縮性に働くが，下垂体剔出ラットでは全く逆で，かえつて副婜皮 質の萎縮防止作用がある点である (Cưuly 1938 ${ }^{14)}$ ), Leathem 1943136), Leonard 19441138), Zizine 1950236))。 ま た Cotisone 投与による副腎萎縮が Testoid な投与するととにより，組織化学的に，また副腎重量隇少が共 に防止される点が知られている (Gaunt 1952(7), Gaunt 195379), Winter, Holling and Stebbins 1953224)). か 〉る Testoid の副留保持作用は Testoid に上る直接作用とも考えられるもので，ての萎縮防止は細胞の大 きさが保持される結果であるとも云われている (Leonard 1942)137)。 また幼若雌ラット副袩皮質細胞の細胞 分裂機能は Testosterone により著しく无められる事実も知られている (Nathanson and Brues 1941) ${ }^{163)}$. 必 〉る意味加らも Testoid は一面に於て AGTH と同様の作用を有するのである. 副腎 Enucleation の場合 の Testoid の増殖促進作用は，上述の Testoid の特異作用と関聯があるかも知れない。とにかく此の実験 に於ては，副腎再生増殖に及ばす亦ルモンは ACTH のみとは考え難い結果である。併し Testoid 投与時 にみられる再生促進像は ACTH 投与時にるられる再生促進像とは幾分異つた所見を呈するものでらつて，

Testoid 投与時には結合織様細胞の增生が特に顕著である。また中心部の結合織性增殖も顕著であつて, 此 等の成分が再生副腎重量増加の一因となすとも考えられる，しかしまた実際には，皮質細胞成分も非常に多 数再生している．またての場合の再生皮質細胞内には殆んどリポイド顆粒がないが，てれは副腎皮質機能立 進時の状態であるか力否汃につては，判定を下すてとは困難である。というのは Testoidは一般に，副堅皮 質のリポイドを減少せしめる点が知られて打り (Hall and Korenchersky 193899), Selye, Rowley and Hall

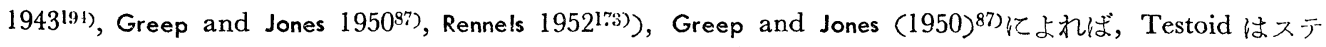
ロイド産生藏器の機能を弱め, コレステロールの減少を来すと云い, 更にとのコレステロールの減少はホル モン前階物質の形成の抑制によるものと認めている.

また Testoid 投与時は ACTH 投与時とは異り，副腎皮質アスコルビン酸在減少せしめないと之が知ら れて和り (Lewis, Demajo and Rosenberg 1949) ${ }^{139)}$ ，汃〉所見加ら Testoid 投与時の副腎皮質機能の判定 は極めて困難で，Deane その他による副腎皮質機能判定の組織学的指標の模型図は Testoid の場合には通 
用しないものである (大樋 1956)16n)。また Testoid 投与時には一般に，副腎皮質に spheroid body や脂肪 細胞化生が出現するが，Selye によればての脂肪細胞化生は Testoid による特異的な反応であり，特に Testoid と下垂体エキスを投与した場合に顕著であると述べている。併し副腎 Enucleation ラットに Testoid を投与した場合には，余り著明な脂肪細胞化生の出現を認めなかつた。 Enucleation 後には下垂体より の ACTH 分泌が極めて旺盛であり，従つてかつる状態時に Testoid を投与した場合には，当然多数の脂 肪細胞化生の出現するてとが予想される.

脂肪細胞化生については大樋 (1956) ${ }^{165}$ )が詳細に検索して扔り，下垂体剔出時にも M.A.D. で著しく出現 する專実を認め, むしろ Testoid の副腎に及ぼす直接作用と考えている。一般に Testost. prop. と M.A.D. 投与 Enucleation ラットの皮質再生像に及ばす相異は殆んど認められないが，M.A.D. 投与の場合は被膜性 結合織の堌生がや〉顕著なもののようであつた。

副婜 Enucleation ラットは一般に良好な体重増加を示すととは第 1 編に於て述べたが，Testoid を投与し た埸合には更に体重曲線は上昇し, 特に雄ラットの場合には著しい増加を示した (第7 表). Testosterone propionate, M.A.D. は発育促進, 窒索平衡の点に於て anabolic action のあるととが知られている (Kochakian 1949199), Homberger Kasdon and Fishman 1950102))。 か〉る Testoid の anabolic action は身体の多くの組

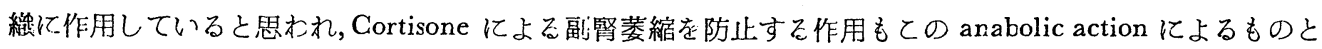
考えられている.また一方ての同化作用は身体のすべての組織に於て証明出来ないとも云われている(Winter

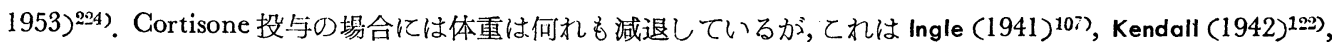
Wells and Kendall (1940) ${ }^{216)}$ 等の述べている如くCortisone による growth inhibition の作用と思われる. 休重及び再生副腎重量の点に於ては，Cortisone と Tesroid とは全く反対の作用がみられるが，両者を併用 した埸合には，Testoid 投与による再生促進作用も消失し，Testoid 投与による体重增加作用も不明確とな つている. 一般に Testosterone propionate は Cortisone による生長阻止作用に拮抗すると云われ (Gaunt 1953) (99)，また Testosterone は正常組織に於て，Cortisone のある作用に拮抗するとも云われている(Pearson $1951)^{168)}$. また臨床的にも Cortisone, Androgen を投与した場合には, Cortisone の catabolic effect を防 ぐと云われている (Kinsell et al 1951123), Luft and Siogren 1951145), Clark et al 195139). 併しまた一方, Cortisone による体重・発育減退は Testoid により防止されないという報告もある (Winter et al 1953)224). 副留 Enucleation に Cortisone と Testosterone propionate を併用投与した場合は再生副腎重量は, 両木 ルモン単独投与時の中間值を示し, 組織像も両者の中間に值した。 やはり再生増殖力の点に於てもCortisone と Testoid と汸反対の作用を有する如く見える.

Cortisone 投与に上る副婜皮質の萎縮は，下垂体 ACTH の狳抑制の結果と考えられている (Ingle 1938)1.5). このととは前以て皮質ホルモンを投与して打くと，Stressによる副腎皮質のアスコルビン酸の減 少が防止される点加らう明かである (Sayers and Sayers 1948)1てi9). それ故 Cortisone 投与の場合には， Enucleation の再生過程を抑制するてとは当然想像出来る。併し正常ラットに Cortisone を投与した場合に は，主に副婜皮質の束状带の菱縮が著明であり，球状带はかえつて巾が広くなり，リポイドも増加してくる (Wells and Kendall 1940216)，Winter 195022i)，Winter 1953221)．，即ち下垂体剔出時に於ける副腎皮質像にか

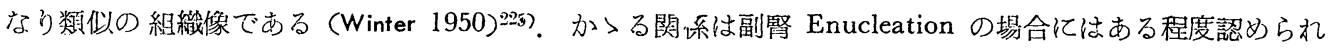

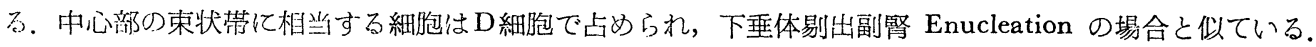
作し，ふンるD細胞の出現は比較的少く，菱縮性ではあるがやはり束状带と思われる細胞の再生がかなり認

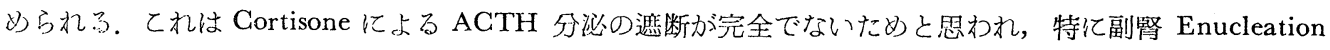
の易合には極妨て大量の ACTH が分泌されるてとが予想さ机て抢り，再生を抑制するには極めて大量の Cortisone を必要とする結果と思わ机る (Ingle 1938 a) ${ }^{105}$ ). Enucleation ラットに Cortisone を投与した

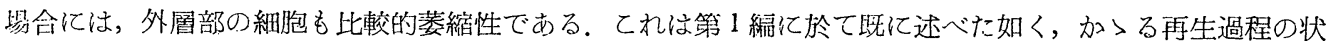
態に於ては皮質細胞は未だ球状带と束状带とが明確な機能局在性を示していないためと思われる。

DOCA 投与による副腎皮質の萎縮も下垂体前葉 AGTH の分必の抑制によるためと考えられている、 
DOCA 投与時には束状带が Cortisone と同様に菱縮すると述べているものがあり (Carnes, Ragan, Ferrbee and Q'Neil 194137), Selve and Dosne 1940191)), Stress のとき扔とる副腎肥大を DOCA が防止 (Woodburg, Cheng, Sayers and Goodman 1950)226)，サイロキシンによる副腎肥大を防止 (Hoen, Lanyffeld and Oehme 1939) ${ }^{100)}$, Estrogen による副腎肥大を防止 (Albert and Selye 1942)3), するものと云われている. これらは DOCA による下垂体 ACTH の分在抑制によるものと考元られるが，DOGA の下垂体 ACTH 分泌抑制作用は, Cortisone の3心さされ (Sayer and Sayer 1948)179), Selye and Dosne (1942)191)は大量の DOCA の ACTH 分泌抑制は alarm reaction の際の副腎反応を防止するのに充分でないと述べている. また Miller $(1950)^{153}$ ) は一側副腎剔出時に於ける他侧の代僧性肥大を, DOGA が防止し得ないてとを述べ ている.また Miller (1950) ${ }^{153}$ は一側副腎剔出時に於ける他側の代償性肥大を DOGA 力防止し得ないてとを 述へている. 即方 DOCA は Cortisone に比し作用ががり弱いものである. Wells and Kendall (1940)216)は DOCA を 3 日打学に 9 日間投与しても副腎の萎縮がみられず, Cortisone は一方 8 日目に著明な萎縮がるら れると述へている。作し DOCA $2 \mathrm{mg} 20$ 日間ラットに投与した場合には軽度の萎縮, $10 \mathrm{mg}$ では更に強い 涹縮が扑てると述べられて打り (Selye and Dosne 1940) ${ }^{191}$ ， 大量投与すれば全㐿の萎縮がねられるという (Sarason 19431'i6), Delecastillo 1945 ${ }^{533)}$ ).

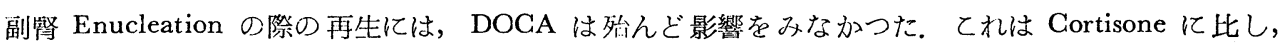
ACTH 分泌抑制力か溺い点を考うれば当然と思われる。 また DOCA は下垂体 ACTH の分泌を低下して 副腎皮質を萎縮せしめる以外に，球状带を撰択的に萎縮せしもる点があげられている。 (Carnes 1941 ${ }^{37}$ ), Miller and Fiddle 194215の) ). 汃つ作用は ACTH を介さない直接作用に属する. (Sarason 1943166), 大樋 1956165)．からる球状带の特異的な萎縮作用は Enucleation 15日目の副腎には認妙られない。この時期は 第 1 繧に於て既に述べた如く, 両凰の細胞の判別は困難であり，機能的にも局在性が明確でないためと思わ れる. Deane一源が述心゙ている如く，球状带と束状带とは二元的な構成であれば，球状带は DOCA 投与に 上り，全く特異的な反応が出現すべき筈である，汃〉る点は特異な条件下に於ては，球状带と束状带との機 能局在性は保持されていないものと思われる．即ちか〉る条件下に於ては球状带に相当する細胞が束状带機 能を代償しているという実験結果もかなり挙げられている。球状帯は一般に DOCA の如き鉱質コルチコイ ドを分佖する層にして，DOCA を投与した場合球状帯が廃用性萎縮を来すものと考元られている。しかし 前にう述べた如く，副婜皮質細胞は外風部から内風部に向つて増生するもので，従つて球状帯細胞は内層部 の皮質細胞よりも幼若な細胞である。，それでか〉る㭃若な球状帯細胞は，特に DOCA の毒作用によつて萎 繀すると解しているものもいる，若しての説が正しいとすれば，何故 Enucleation 後新しく再生される皮 質細胞は，DOCA に上つて萎縮しないのであろうか。.また束状帯細胞が出来上るには，一度球状帯を通過

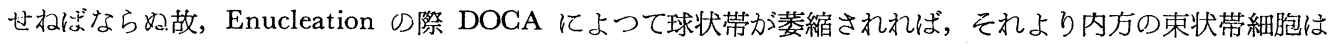
全く再生されてい筈ではなからうか. 併し私の実験では，DOCA 投与時にも内首部の細胞も完全に再生さ れ，また外楅部の細胞も普通の副腎の如く撰択的に萎縮を来すととはなかつた。てて等の結果及び他の実験 上り，私は次の如き説明を述べょうと思う。

即ち，副腎皮質各層の機能局在性は正常時には比較的明確に立証しうるが，特別な場合には成り立たない。 Enucleation の場合は特別な例であつて, 特に再生初期に於ては機能の分化が進んでいないものと思われる。 ての埸合外凰部皮質細胞も束状帯細胞の機能を発揮するものと考えられる。また第 1 編に於ても述べた如く, 再生初期には組織学的にも球状带と束状帯とは明確に区分するてとが出来ない。末た機能的にも球状帯と束 状帯とは明確に区召するととが出来ない点を述べたが，第 3 編に於ても全く同様の結果である。しかし一応 皮質細胞の再生が完成した後には，DOCA に卡つて球状带は萎縮し，また組織学的にも球状带と束状带と は明確に区分するととが可能となつてくる。

以上の点汃らも明かな如く, Deane 一派の考えている如き，球状帯と束状帯とは二元的構成とみなす説は 价しくなく，やはり皮質細胞は一元的なものであつて，機能的には分化したものと考えざるを得ない．安藤 $(1953)^{8)}$ は皮質細胞は一元的な堌殖を示すものであつて，併も分泌，機能は局在的に分化してくるものと述 べている，ての Enucleation の実験は更に一元的機能局在説を裏付けるものである、 


\section{去勢による影䠛}

一般に雌シット副腎は雄ラツト副粲よりも大きく，且つ組織化学的に雄副腎は sudanophodezone があり， 雌ラットには不明確な点から，雌副腎皮質機能は雄副腎皮質機能より亢進した状態にあるものと考えられて いる. (Greep and Jones 19508i), 田所 1954207), 大樋 1956165))。去势により，雄ラット副腎は肥大し，雌う ット副腎は萎縮する点から，体内の Estrogen·や Testoid がてれら副腎皮質機能の雌雄二型性に原因してい るものとされている，即ち体内の Estrogen が皮質機能を元進せしめ，Testoid は皮質機能を低下せしめる ものと云われている，去勢による副腎皮質の組織学的変化は，体内性ホルテンの影響がなくなつた結果発来 する変化と考えられている。 また卵剔によつて ACTH の分泌が抑制されることが知られている（Ellison and Burch 1936) $)^{66)}$. それ故去勢時に於ける副腎 Enucleation の再生像には，汃なり異つた所晃が認められ てよい筈である．ての実験では雄ラット去勢時には殆んど正常ラットと差がなかつつかが，雌ラット去勢の場 合には，再生副腎皮質はかなり萎縮性であり，且つ写真の如く中心部はすべてD細胞で占められていた．即 ちてれは AGTH 分泌低下時にみられる像であつて，去勢によつて ACTH の分泌か抑制された結果とみる べきであらう．特に副腎 Enucleation 再生増殖には既に第 1 編に於ても述べた如く, 極めて大量の ACTH の分泌によつて遂行されるものと考えられるために，卵巣剔出によつて Enucleation の再生もかなり抑制 されるととが想像される。

一方卵巣剔出によつて，副腎皮質機能は何等変化しないと述べているものもいる.(マウス Haward-Miller 1927104)，ラット Sarason 1943176)，モルモツト Zalesky 1936234)). 然してれは一般に卵栄剔出の時期と実験 の長さにより生ずる差異と考えられている. (Anderson and Kennedy 1933i), Blumenfeld 193926), Sarason 19431:(7). Ellison and Burch (1936) ${ }^{66)}$ は卵巣剔出によつて副腎は始め肥大し次いで萎縮するてとを述べてい

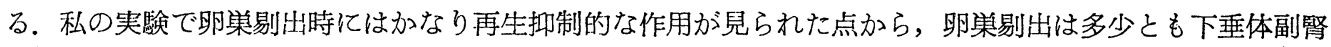
系の機能を修飾するものの如く思われる，一方雄ラット去勢時に於ては，再生像には著明な变化が見られな かつた。一般に雄ラット去势によつて副粲皮質は肥大するもので，之は Androgen が下垂体 ACTH の分 泌を抑制しているためと考えられている。 それ故，雄ラット去勢時には副腎皮質の再生像も促進されるべき 䈱のものであるが，䏍述の如くTestoid 自体には再生増殖する作用があり，此の場合に於ける再生増殖力の 問題は一㬝複雑な因子が介在している様に思われる。

\section{第 5 章 要約}

1). 副腎 Enucleation 後の再生は，ACTH 投与または下垂体 ACTH の分泌を促す如きホルモン (Estrogen) によつて促進される，このことは，AGTH が副腎皮質細胞の増殖をも支配しているととによるものと 考えられる。

2). 併し,ACTH以外に生長ホルモン, 男性ホルモンもまた著しい再生促進作用を有し，乙のととはACTH のみが副腎皮質を支配する唯一のホルモンでないととを示すものと考えられる。

3). Corisone によつて再生は著しく抑制されるが，乙れは下垂体 ACTH の分泌を㧕制するためと思わ れる. DOGA には殆んど抑制的な作用は認められなかつた，とれは DOCA は Cortisone よりも下垂体 ACTH の分泌を抑制する力が弱りためと思われる。

4). 雌ラツト去勢時には, 副腎 Enucleation 後の再生はかなり抑制される.

5). 以上の実験加副腎皮質細胞は一元的な増殖を示すもので, 再生初期に於ては, 内外二層の機能局在 性汃归磼でない，全く再生が完成した後には，内・外二图には機能局在性が認められてくる。

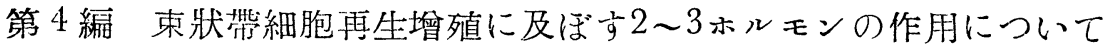

第1章 緒言

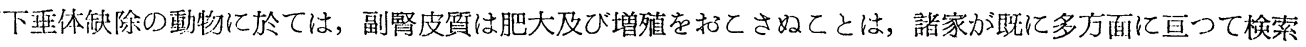


している，併し私は第 2 編に於て，下垂体缺除時に於ても副腎皮質外圓部は比較的自律的に増生を扣てし， 且つ一見分泌機能を発揮しうる如き所見を示す点について述べた。しかしての場合に於ても，队圏の束状带 に相当する細胞は全く再生されず，同個所には翌性萎縮性の細胞が代りに出現するものであつて，此等の点 加ら，内層の束状带細胞が出来るために惊，更にまた束状帯が分泌機能を発揮するためには，下垂体ホルモ ンが必須であるととが予想せられた。

副腎皮質の三層形成には下垂体が必須であるならば，果して下垂体の如何なるホルモン因子がてれに関与 しているのであ万うか。本編はてれらの帮験的研究を主体として検索してみた。

飶㳊第 3 編に於て，成長ホルモンと男性ホルモンが ACTH 以外溞い再生増殖作用を有するととを知つ たが，しかしての両ホルモンのか〉る作用は下垂体の健常な埸合の所見であつて，てれら両ホルモンの独自

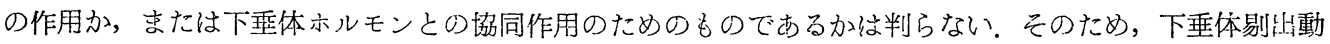
物に各種ホルモンを投与しない限り，このホルモン自体の作用加否加は見出すととは出来ない.

従来加ら球状帯細胞が被膜汃ら堌生する点に関しては，かなりの実験專実が認多られているが，束状带細

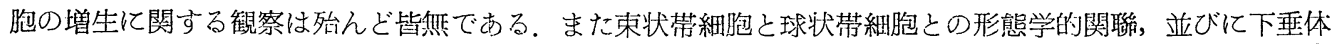
支配の関聯の本に，乙の問題は明示されねばならない，束状带細胞は下垂体の如何なる因子の本に，また何 処の個所加再生増殖する汃という点に関しては, 従来実験的に殆んど検索されていない. 私は下垂体剔仙

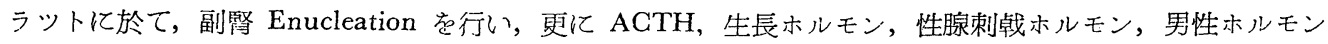
を投与して束状带細胞が如何なるホルモン因子によつて再先増殖するかる検索してみた。

\section{第 2 章 実験材料及び実験方法}

実験動物はすべて150g前後の䧳ラットを使用した。下垂体剔出法及び副婜 Enucleation の術式は第 1 繶， 節 2 緛の如くである。. 副腎 Enucleation 1 日後より下記各種ホルモンを投与し, Enucleation 手術日より 15日目，23日目に屠殺した。

符1 群 下垂体剔出+Enucleation 15日

第 2 群 下垂体剔出 + Enucleation+Test. prop. 15日

第 3 群 下垂体剔出+Enucleation+生長ホルモン 15 日

符4 群 下垂体剔出+Enucleation 23日

第 5 群 下垂体剔出 + Enucleation + ACTH 23 日

第 6 群。下垂体剔出+Enucleation + gonadotrophin 23日

Testosterone propionate 1 日量 $2.5 \mathrm{mg}$, AGTH (Amour) は $2 \mathrm{mg}$, chorionic gonadotrophin は 1 K.E.を連日皮下若しくは筋肉内投与した。

副婜その他藏器の計測は，第 1 編に同じ。また標本も同様各種染色法により作笠した。

\section{第 3 章 実 験 結 果}

\section{再生副腎重量:}

各群の再生副腎重量は第 8 表の如くである. Testosterone prop. 投与群でや〉著明な副腎重量の增加が認 められたが，ACTH投与群では予期に反して，それ程著明な増加はみられなかつた。 下垂体剔出と Enucleation のみの対照仗15日後も23日目の場合も, 殆んど差がるられなかつた. Gonadotrophinも殆んど対照と の間に，差が認められなかつた。

\section{組織学的所見:}

第 1 群並びに第 4 群の対照例は, 第 2 編に既に所見は述べたから，てつでは省略する，唯，15日群のもの も23日群のものも，組織像並びに組織化学的所見とも殆んど差がみられてかつた，即ち下垂体剔けラット

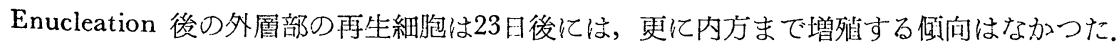

第 2 群 Testosterone propionate 


\begin{tabular}{|c|c|c|c|c|c|c|c|}
\hline & \multirow{2}{*}{$\begin{array}{l}\text { 実験 } \\
\text { 日数 } \\
\text { (日) }\end{array}$} & 体重 & $(\mathrm{gm})$ & \multicolumn{2}{|c|}{ 副腎重量（mg） } & \multirow{2}{*}{$\begin{array}{c}\text { 胸 腺 } \\
\mathrm{mg} / \\
100 \mathrm{gB} . \mathrm{w} .\end{array}$} & \multirow{2}{*}{ mg/ } \\
\hline & & 開始時 & 終結時 & 右 & 左 & & \\
\hline $\begin{array}{l}\text { 垂体剔出 } \\
\text { 十副整 Enucleaiion }\end{array}$ & 15 & $98 \pm 4$ & $94 \pm 12$ & 剔 出 & $2.3 \pm 0.5$ & $129 \pm 15$ & $1002 \pm 32$ \\
\hline $\begin{array}{l}\text { 下垂体剔出 } \\
\text { 七副腎 Enucleation }\end{array}$ & 23 & $141 \pm 8$ & $122 \pm 8$ & 剔 出 & $3.2 \pm 0.8$ & $147 \pm 27$ & $876 \pm 20$ \\
\hline $\begin{array}{l}\text { 下垂体剔出 } \\
+ \text { 副腎 Enucleation } \\
+ \text { ACTH }\end{array}$ & 23 & $132 \pm 11$ & $114 \pm 15$ & 剔 出 & $3.5 \pm 0.7$ & $210 \pm 26$ & $1100 \pm 35$ \\
\hline $\begin{array}{l}\text { 下垂体剔出 } \\
+ \text { 副㱟 Enucleation } \\
+ \text { +生長ホルモン }(0.25 \mathrm{cc})\end{array}$ & 15 & $133 \pm 13$ & $125 \pm 15$ & 剔 出 & $4.2 \pm 0.7$ & $207 \pm 38$ & $876 \pm 31$ \\
\hline $\begin{array}{l}\text { 下垂体剔出 } \\
+ \text { 副腎 Enucleation } \\
+ \text { Test. prop. (2mg) }\end{array}$ & 15 & $146 \pm 12$ & $143 \pm 16$ & 剔 出 & $5.7 \pm 0.6$ & $165 \pm 28$ & $871 \pm 31$ \\
\hline 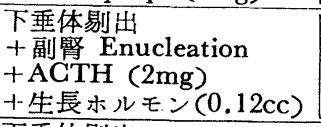 & 15 & $112 \pm 3$ & $108 \pm 12$ & 剔 出 & $5.8 \pm 0.3$ & $312 \pm 20$ & $1048 \pm 28$ \\
\hline $\begin{array}{l}\text { 下垂体剔出 } \\
\text { +副竪 Enucleation } \\
\text { +ACTH (2mg) } \\
+ \text { +Test. prop. (2mg) }\end{array}$ & 15 & 123 & 98 & 剔 H & 2.5 & 38.7 & 1070 \\
\hline $\begin{array}{l}\text { 下垂体剔出 } \\
+ \text { 副腎 Enucleation } \\
+ \text { gonadotropin(1 K.E.) }\end{array}$ & 23 & 117 & 95 & 剔 出 & 1.5 & 82 & 747 \\
\hline
\end{tabular}

第9表 下垂体剔出ラットの副腎再生に及ぼす影響(重量 $\mathrm{mg}$ )

$m g$
6

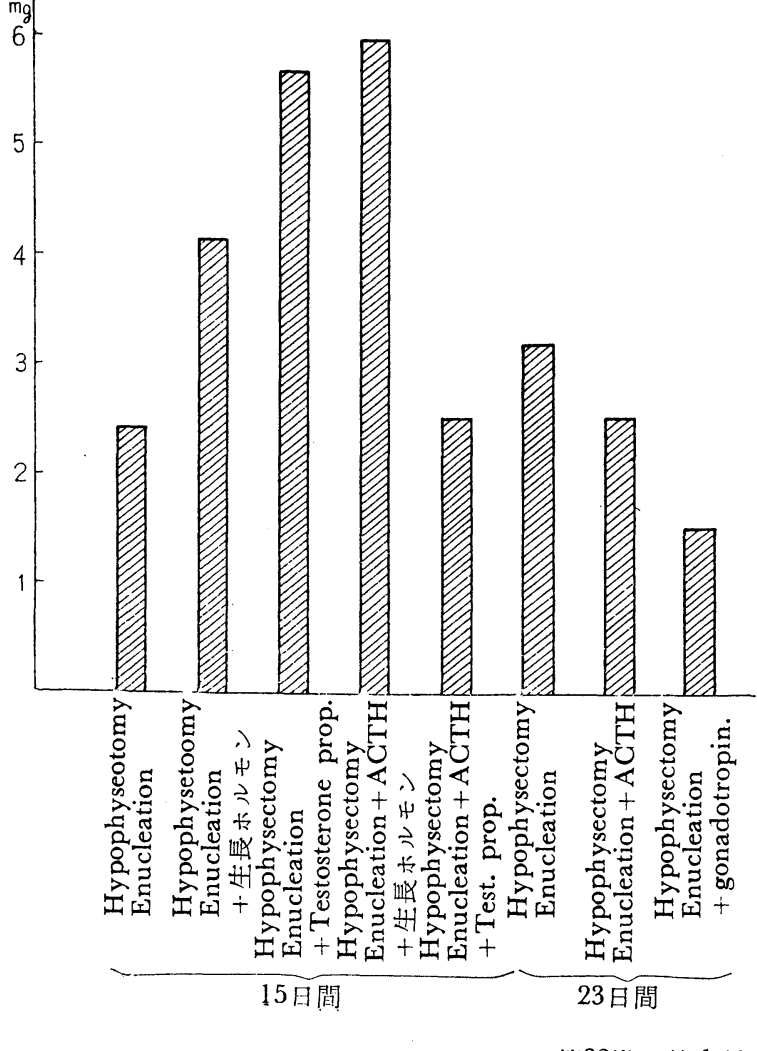

ての例では明かに，再生副腎の大ささが 大であるが，組織学的には再生像は何等 著明な促進がみられなかつた。しの場合 大きな副腎の容積を占めるのはD細胞群 であつて，再生副婜中心部は卶んどこれ らのD細胞で占められている。被膜下の うすい周辺層は，対照と同様に $\mathrm{R}$ 細胞力シ 完成している。 R 細胞は明かに皮質細胞 の形態を整え，第 2 編で述べた如く球状 带に相当する細胞と考えられ，D細胞群 は萎縮した束状带細胞と考えられる。尚 此の場合には層的判別は極めて著明であ り，外層蔀の $\mathrm{R}$ 細胞群は明方々球状带細 胞と断定しうる所見である。このR細胞 も一般に細胞は非常に小さく, 配列がや >索状を呈して扣り，第 2 編に於て述べ た $\mathrm{R}$ 細胞と同じくリポイド顆粒は殆んど 含有されていない．とのR細胞帯の下部 には移行首と思われる層は全く存在せず, 直接中心部大半古占めるD細胞群に移行 している。D細胞はすべて萎縮性の細胞 で，核は偏在性の pycnotic ないしは核 崩堎像の多い細胞で，下兲体剔出時に出 
現する束状帯細胞とその様相を酷似している。また中心部にはかなりの結合織が進入レており，てれらの萎 縮性細胞内には黄褐色の色素が極名て大量含有されている。 Sudan 染色で中心部のD細胞群は粗大滴状に 染り, 褐色色素も同様に陽性である.Schiff, Schultz 反応でもD細胞は若干程度は弱いが滴状に染るが，褐 色色素は染らない．またD細胞は Nile blue で淡紅色に鮮に染る。てれらの組織化学的並びに組織学的所見 は，下垂体剔出時の菱縮性束状帯，網状帯の細胞と略々同様の所見である.

\section{第3 群 生長ホルモン}

組織像は略々対照群と同様である。即ち周辺部にはうすいR 細胞帯の再生がみられ，中心部は $\mathrm{D}$ 細胞群で 占めらる. 尚 $\mathrm{D}$ 細胞は Testoid 投与群に比し量が少ない. 組織学的, 組織化学的並びに色素の態度は殆んど 第 2 群と同様である.

\section{第 5 群 ACTH}

組織学的に内外二層を判然と区别するてとが容易で，球状带は好塩基性の細胞で，細胞の形は小さく，そ の下部には束状配列の束状带細胞がかなり中心の方まで再生している。併し全体としての大きさは殆んど刘 照群と差がるられない，乙の場合にみられる球状帯は第 2 編に於て述べた球状帯の如き，はつきりした束状 の配列を示していない，且つまた，乙の場合の球状帯の巾は著しく㹨く，細胞7～8個の巾である。一般に 球状帯細胞はクロマチンが多く，その下部の束状帯細胞とは明瞭に区別するととが出来る. (写真31). 束状 带細胞は束状に配列し，細胞の大きさ结球状帯細胞より幾分小さく，細胞内には微細な空胞を有する，組織 化学的にも球状帯は，一般にリポイド顆粒が少く，微細であり，まだは殆んど陰性と云つてよい程少い． 一方束状帯は微細な顆粒が非常に多く, 組織化学的にも球状帯, 束状带はきわ邓て明確に区別し得る(写真 32).

\section{第 6 群 Gonadotrophin}

組織学的には下垂体剔出副堅 Enucleation の場合に佲んど一致して扔り，周辺部には球状帯が再生して

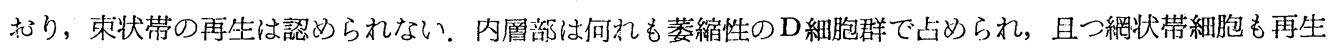
されている像は認められな加つた。

\section{第 4 章 考案}

副腎皮質に於て下瑇体爷配の最も強く関与している部位は束状帯であり，球状帯は下垂体には余り強く影

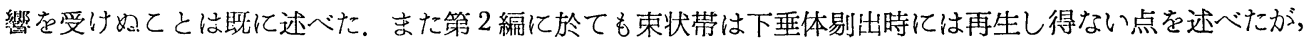
ての編に於ては，如何なるホルモンを補足すれば束状帯が再生し得るか，即ち副腎皮質首形成は如何なる木 ルモンの支配下に遂行されるかを検索したのである。をして実験の結果は，ACTH のみがかる圈形成能 才がある点を知つたのである。下垂体剔出時に於ても球状帯は再生し得るてとは第 2 編に述べたとてろであ るが, それ以下の風の形成には市垂体が必須であり，下垂体缺損時には束状帯への形成が停止する如く考えら れるのである。下垂体剔出時に再生する球状帯は，一般に風の巾がかなり広く，細胞が多数個配列している が，ACTH を投与した場合の球状帯はかえつてうすくなつてきている。とのととはACTH の作用によつ て球状带細胞が束状帯細胞に移行し, 従つて球状帯細胞が少くなつたものと考えられる。加〉る事実は他の

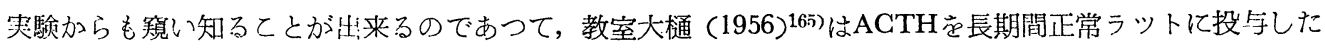
梤合，柬状帯が肥大して大きくなるに反し，球状帯は反対にうすくなるのを認妨てい。またAGTHを投与 した埸合にコンヒチンを用いて核分裂像を観察した際，束状带のみなく球状帯にも核分裂像が増加する事実

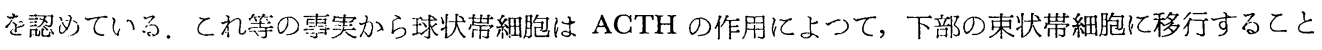
が想像山来るのである。元来副腎皮質細胞被膜の方から再生増殖するものであつて, 球状帯細胞も束状带 紐胞も一連の細胞で単に機能相を異にする点については，既に述べた如くである．また一般に球状帯紐胞は， 來状带紐胞に転換されるものと考えられて打り, Baker (1952)18)はラットで大量の ACTH 投与によつて, 球状帶纪束状带の細胞似てくるととを述べているが，てれは球状带細胞が ACTHにより修飾され，束状 带紐胞に転換するととを示すに外ならない，即ち束状帯肥大のためには，球状帯汃ら細胞を増殖し動員する 
ための一機序と思われる，かくの如く，球状帯紐胞は ACTH の作用によつて下部層への転換を行うととか ら, 球状帯は ACTH に全く作用を受けないとするのは誤りであり, 従来ての点に関しては多くの誤解があ る. 厳密に云うならば，球状帯は下垂体とは独立的とは云えず，自律性があると表現せねばならない，即ち 球状帯は下垂体がなくとも，自律的に増殖しうる能力があるが，その上 ACTH の作用を受け，細胞を束状

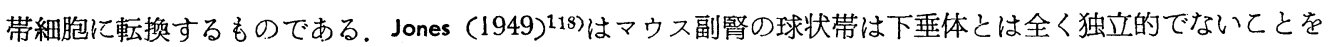
述べて扔り，同様に Wexler et al (1955)1ㄱ) も下垂体剔出ラットの副腎球状带は, ACTH によつて変化す る点を述べているが，てれがために球状帯の自律性を否定する根拠にはならす，むしろ私の上記の解釈から すれば, 球状帯も当然 ACTH の作用を受けて奇異とするに足らぬ. 河原, 青木 (1953) ルモン分泌に関しては，球状帯は支配されないとしても皮質の再生には必要なる点を述べている゙，特に束 状帯細胞の再生には ACTH は必須と考えられる。ACTH 投与時に初めて束状帯細胞が再生してくるが， てれらの細胞は細胞内に多数の小型の空胞を有している. 束状帯細胞に於ける空胞形成については ACTH 投与 (Baker 1952)18)，または ACTH の分泌を促進する諸種のストレス (Deane and Shaw 194751)，大樋 1956165))の場合に認められ，特に刺㦸が長期間持続したときに出現するものと考えられる. 安藤 $(1953)^{81}$ は 塩化カリ，塩化カルシウムを長期間投与して球状帯が肥大，機能宁進状態を示す場合に，球状帯に同空胞の 出現することを述べている，即ちかかるる空胞の出現はホルモンの放出と関聯がある様で，Rennels (1952)1:3) は discharge body なる名称の本に ACTH 投与時に出現するてとを述へている。てれらの点からみても， との場合の束状帯の空胞形成は ACTH の作用によつて出現したてとは容易に想像され得る。そしてまたか 〉る束状帯細胞はりポイド顆粒が微細でかつ多く，分泌機能も保持されているものの如く考えられる。しか し一方出来上つた束状帯細胞はかなり小さく，かえつて球状帯細胞より小さい位である。更に加〉るACTH 投与時に於ても再生副腎の重量は極加て小さく，てのととは全く予期に反した結果であつた。 てれは投与し た ACTH の量の不足に起因するものか，または下垂体剔出後の期間の長さが問題であるかも知れない.

Evans, Pencharz (1933)71) 等は下垂体剔出後時日の経過する程，ACTH は萎縮副腎皮質の恢復を来すとと が困難となり，下垂体剔出後 4 週目では，一般に下垂体剔出後 1 週目に要する 6 倍の ACTH の量で初め て副腎皮質が恢復しうるととを述べている，更に第 3 編に於ても述べた如く，副腎 Enucleation の場合に は極めて大量の ACTH が放出されるととが必要であるた方，量の不足が最も強く原因しているようでもあ る. 特に私の実験では，下垂体剔出後翌日副睯 Enucleation を行い，1 日扣いて直ちに ACTH 投与定開 始し，下垂体剔出後に扣てる副腎の不感受性を極力さけている。同椂の結果は既に Ingle (1942)103)も述べ て打り，大量の ACTH でも下垂体剔出ラット副㛑 Enucleation の皮質再生を治んど促進しないと述べて いる，そしてかつる結果は，Ingle をしてもかなり予期に反した事実として取り上げさせている，彼は一般 に副婜皮質の再生は，ACTH によるものと信に゙ているため，ての説明は甚だ困難で，多分再生に要する AGTH の量は非常に大量を要するのか，または他に再生過程を活性化す百ものがあるかも知れないと述べ

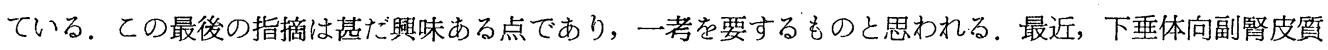
刺㦸ホルモン中には，二つの因子があり，一つは Adrenal weight factor (A.W.F.) で他は Ascorbic acid factor (A.A.F.) である (Dixon, Stack-Dunne, Young and Cater 1951)57). 前者は副婜アスコルビン酸減少作 用は弱く, 副腎重量を保持する作用がありまた Subglomerulosa, Sudanophobic zonesのリポイドを著し く増加しまたての部の核分裂像を著しく増加させると云われる。即ち A.W.F.は下垂体剔出ラットの steroidgenesis を扎てさ妨もので, growth promotion に関与するものとされている. A.A.F.はか〉る growth promotive の作用はなく， steroid synthese 及び放出に関与するもので，両因子共に副梷皮質か讁度の機能 を発揮するに必要であると云われている(Bush) ${ }^{33)}$. また A.W.F. は生長ホルモンではないかとも考えられ ている。私の行つた失験でも，ACTH が副腎重量を大してて増加せしぬ得なかつた理由もかつる点に起因す るの加も知れない.

第 3 編の奉験の結果から，Testoid，生長ホルモンが著明な再生増殖作用が認められたが，本編の下垂体剔 出ラットに於ては，Testoid も生長ホルモンも束状帯細胞を再生堌殖せしめる能力がなかつた，Testoid の 
埸合は周辺部の球状带の他に, 中心部に $\mathrm{D}$ 細胞群の形成が顕著であつたが，何れも萎縮性である. 生長ホル モン, 胎艋性性腺刺㦸ホルモンも機能的な束状帯細胞を再生するととはなかつた. 即ち Testoid, 生長ホル モンの再生堌殖促進作用は下垂体ホルモンと協同の本に発揮されるものの㥞であるが，一方私が用いたホル モン量が過少であつたをみに束状带細胞を再生し得なかつたのかる知れない.

結满として私は，副婜皮質細胞の増殖過程に及ぼす下垂体との関係を，次図の如く示した。

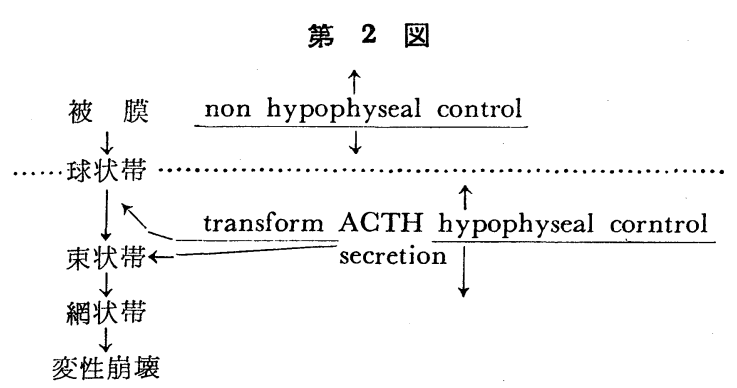

皮質細胞の life history をみるに，上記の 如く被膜ふら球状带までは下垂体とは自立的 に増殖し, 球状带 $\rightarrow$ 束状帶 $\rightarrow$ 網状带への増殖 過程は下垂体支配の本に遂行されるものと考 えられる.また束状帯の機能は下垂体AGTH の作用の本で, 初めて発揮される様㐾える。 Zalesky (1941) ${ }^{235)}$ は Ground squirell に於 て, 正常時に於ては Glomerulosa $\rightarrow$ Fasc. $\rightarrow$ Reti. A $\rightarrow$ Reti. B という Cycle で細胞が増 殖するのであるが，下垂体剔出時に於ては active functional phase を介するてとなく Retic. B に移行し変 性崩垻するととを述べている。副腎 Enucleation ラットの場合に於ても同様であり，正常時には被膜内細 胞 $\rightarrow$ 球状帯 $\rightarrow$ 束状帯 $\rightarrow$ 網状帯と移行して変性崩埕するのであるが，下垂体剔出時には被膜内細胞 $\rightarrow$ 球状帯 $\rightarrow$ 変性崩壊の過程をたどる樣に考えられる。

\section{第 5 章 要約}

1. 束状带細胞は下垂体の存在の本に於て初めて再生しうるもので, AGTH はての増殖過程を支配する ホルモンと考えられる. 即ち ACTH によつて球状帯細胞から束状帯細胞が出来上り, 束状帯細胞は分泌機 能を営むものと考えられる。

2. 男性ホルモン・生長ホルモン・胎盤性性脉刺战ホルモンなどは, 球状带細胞を束状带細胞に転換せし ぬ得なかつた。

\section{第 5 編 全 編 $の$ 総 括}

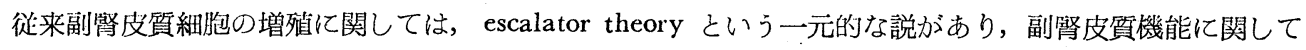
は zonal theory という二元諭があり, 互に対峙した説となつている. か〉る問題の解決には, 副腎皮質細 胞の増殖機構と機能との二面から検索する必要がある。私は副腎 Enucleationの実験を行い, 球状帯細胞 と束状带細胞との増殖, 並びに両凮の機能的差異, また特に雨首の相互関係を下垂体支配の影響と共に検索 した.

副紧皮質細胞の増殖個所, 乃至增殖源は, 被膜または被膜下の fibroblast 樣細胞であるととは, 副腎 Enucleation の実験でも確められた。 即ちコルヒテンを用いた観察によれで゙, 再生初期には被膜内に数多く の分裂像が捕捉され，また副腎 Enucleationの場合には，被膜下細胞の增生が旺盛となる事実加らも明心 である。被膜または被膜下から堌生した皮質細胞は，次第に内方に escalate する様にみえるが，副腎 Enucleationの場合には，すべてての增殖形式を示すものとは限ら奴。被膜下に於て皮質細胞に転化するもの以 外に，皮質内凰に於ても核分裂により增殖が行わ机，更に皮質原基が一旦皮質内に進行して，そてで metamorphosis を行ら形式がみられた。併し副腎皮質細胞は一般に Salmon，Zwemer，Bennett 等が述べている如 く, life history の極好て短いもので, 原則的にはやはり escalation による形式が多い様に思われる。

副督 Enucleationの場合再生は略々 1 ケ月で完成し, 内層部細胞も出来上り, 組織学的, 組織化学的に も略々正常皮質像に復する. Thorn test は大体ての時期に到つて陽転するもので, 副緊皮質機能も略々此の 
時期に元に復するものと思われる。

球状帯細胞は一般に自律的に電解質代謝ホルモンを分泌するもので，下垂体の支配を受けないものと解せ られている，第 2 章に於て，下垂体剔出ラットの場合にも球状帯細胞の再生が完全に行われることを述へたた が，てのことは球状帯細胞は自律的増殖能力があるととを示す点である。また下垂体缺損時には束状帯以下 の細胞の再生は全く行われず， ACTH 投与によつて初めて行われる点から，束状帯細胞は増殖の上にも， また機能の上にも下垂体 AGTH の支配下にあるものと考元られる. 更に球状帯細胞は ACTH 投与によつ て，束状帯細胞に転化するものであり，か〉る点に於て球状帯は下垂体とは独立的な㬝というととは出来な い. 即ち笽密に云えば，球状帯細胞は自律的性格が強いが，更に下垂体 ACTH の作用によつて束状帯細胞 に転化する性質のものと考えられる。

副腎皮質細胞の再生・増殖を刺㦸するためには極めて大量の ACTH 分泌が必要と思われる。一側副腎が 残存している場合には，再生が著しく痋延し，下垂体剔出ラットで束状帯細胞を再生せしりるためには，大 量の ACTH 投与を必要とし，とのととは副腎皮質の分泌を刺㦸するよりも，再生を刺㦸するうが量の ACTH を必要とする様侤えられる。，それ故副腎 Enucleation 後の再生を促進するには，大量の ACTH 投与下垂体 ACTH の分泌を高める諸種の Stress 要因が必要である.

ACTH によつて再生は著しく促進されるが，この実験では尚，男性ホルモン，生長ホルモンが著しい再 生促進効果を示した。とのととは副腎皮質が単に ACTH のみによつて支配されているとみなす Sayers (1948) 一派の一元論では説明し難い事実であるる.

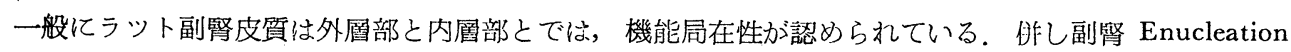

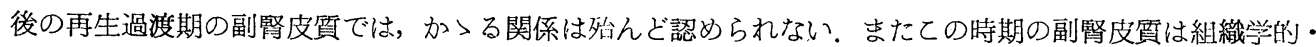
組織化学的にみても，球状带と束状帶との凮的区別は明確でなく，正常副腎の如く二層を分離するととは出 来ない. また副督 Enucleation 後再生が未だ極りて僅かしか行われていない時期に於て, 已に副袩不全の 徵を来すととなく，また Hartman 等によれば，副腎 Enucleation の後には fat factor が正常以上に分泌さ れることが述べられて打り，乙れらのととは，皮質ホルモン分泌能力は内風部のみより行われるものでなく， 外首部の細胞でも比較的大量の皮質ホルモン分泌能力がある点を示すものである。即ち副篮 Enucleation

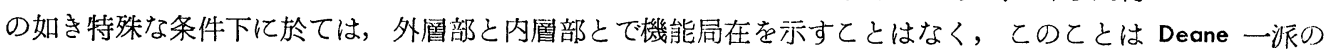
zonal theory は肯定し難い点である. 併し副腎 Enucleation 後1ケ月後には, 両風の区別が組織学的, 組 織化学的にも明確となり, 且つ両痒の反応態度の差異が明確となつてくる. 即ち球状帯と束状帯との機能的 差異は絶対的なものではなく，特殊な環境下に於ては成り立たないものと考えられる.

以上の点上り球状带紐胞も束状带細胞も一元的な細胞であり, 球状帯は自律的に增殖し且つ機能を発揮し 得るが，下垂体 ACTH の作用により束状带に transform し，下垂体支配の本に糖質コルチコイドを分泌 するに至るものと思われる。

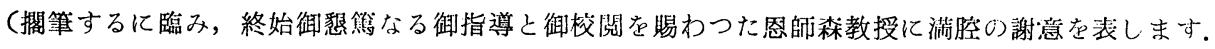

尚, 本吥究に御協力戴いた安藤卓爾博士に感謝致します)

\section{引用文 献}

1）赤須，竹內，宮川：ホルモンと臨林， $2: 1082$ 1085, 1954.

2) 赤須, 竹內, 宮川: ホルモンと 臨休, $2: 12 \sim 15,1954 . \quad 3)$ Albert, S. and H. Selye: J. Pharm. \& Exp. Therap. 75: 308-315, 1942. 4) Albright, F. : Recent Prog. in Horm. Res. 1: 293-353, 1947. 5) Albright, F. and E.C. Reifenstein : The parathyroid Glands and metabolic Bone Disease. Baltimore: Williams \& Wilkins 1948.

Allen, B.M. and H. Bern: Endoc. $31: 586-591,1942$. siol. 79: 1-30, 1933. (Hartman. 1949より引用).

7) Andersen, D.H. and H.S. Kennedy: J. Phy-

8) 安藤: ホルモンと臨床, $1: 218$ 230, 1953. Soc. Exptl. Biol. \& Med. 73 : 262-265, 1950.

10) Antopol, W.: Proc.

11) Arnold, J.: Virchow's Arch. f. Path. Anat. 35 : 
64-107, 1866.

12) Atkinson, W.B., M.M. Dickie and E. Fekete : Endoc. $55: 316-325,1954$.

Bacchus, H.: Am. J. Physiol. 163 : 326-331, 1950.

14) Bacchus, H. : Proc. Soc. Exptl. Biol. \& Med. $76: 391-393,1951$.

15) Bacchus, H., M.M. Heiffer and N. Altszuler : Endoc. 50: 264-268, 1952.

16) Bachmann, R. : Klin. Wochnschr. $22: 783-784,1939$.

17) Badinez, O. and H. Croxatto: Bol. Soc. Biol. Santiago $5:$ 40, 1948. (Deane, H.W. and L.I. Gardner, Endoc. 48:237, 1951より引用). 18) Baker, B.L. : Recent. Prog in Horm. Res. 7 : 331-364, 1952.

19) Baker, D.D. and R.N. Baillif : Anat Re.c. (Suppl) 70:5-6, 1938.

20) Baker, D. D. and R. N. Baillif : Proc. Soc. Exptl. Biol. \& Med. 40 : 117-121, 1939.

21) Baxter, J.S.: J. Anat. 80: 139-146, 1946. (Hartman 1949より引用). 22) Bennett, H.S. : Am. J. Anat. 67 : 151-214, $1940 . \quad 23)$ Bergner, G.E. and H.W. Deane: Endoc. 43 : 240-260, $1948 . \quad 24)$ Bernard, L. and Bigert: Compt. rend. soc. Biol. 54 : 1400-1401, 1902. (Hartman 1949より引用). 25) Bernstein, D.E.: Proc. Soc. Exptl. Biol. \& Med. 73 : 175-176, $1950 . \quad 26)$ Blumenfeld, C.M.: Endoc. $24: 723-738,1939 . \quad 27)$ Blumenthal, H.T. : Endoc. $27: 477-480,1940$.

28) Blumenthal, H.T.: Arch. Path. $40: 264-269,1945 . \quad 29)$ Bogomolez, A.: Folia Serologica $3: 125-$ 155, 1909 (Salmon 1941 ๖り引用). $\quad 30$ ) Brenner, R.M., D.I. Patt and L.C. Wyman: Anat. Rec. 759 1954. 31) Brownell, K.A. and F.A. Hartman: Endoc. $42: 232-235,1948 . \quad 32$ ) Brownell, K.A., F.A. Hartman and R.W. Reiman: Endoc. $47:$ 326-330, 1950.

33) Busch, I. Cited. 34) Cameron, G.R. : Pathology of the cell. Oliver and Boyd Edinburgh. 1952. 35) Canalis, P.: Internat. monat. f. Anat. a. Physiol. 4: 312-334, 1887. (Hoerr 1931より引用). 36) Carlson, H.E. : Endoc. $15: 524$ 530, 1931. 37) Carmes, W.H., C. Ragan, J.W. Ferrebee and J. O'Neill: Endoc. 29: 144-149, 1941. 38) Cellestino, da Costa. A. : Arch. de Biol. 28 : 111-196, 1913. (Hoerr 1931より引用). 39) Clork, W.S., E.L. Manning and J.E. Appleton: J. Clin. Invest. 30:633, 1951. 40) Collip, J.B., E.A. Anderson and D.L. Thomson: Lancet 225 : 347-348, $1933 . \quad 41)$ Conn, J.W.L., L.H. Louis, M.W. Johnston and B.J. Johnston: Proc. Am. Soc. Clin. Invest. 40th. Meet. 11. 1948 (Greep and Jones 1949より引用). 42) Crooke, A.C. and J.R. Gilmour: J. Path. and Bac. $47: 525-544,1938 . \quad 4$ 43) Cutuly, E.: Anat. Rec. 66: 119-122, $1936 . \quad 44)$ Cutuly, E., E. Cutuly and D. Mc Cullagh : Proc. Soc. Exptl. Biol. \& Med. $38: 818,1938 . \quad 45)$ Daughady, W.H. and C.M. Mac Bryde: J. Clin. Invest. $24: 519,1950$.

Deane, H.W. and R.O. Greep: Am. J. Anat. $79: 117-137,1946 . \quad$ 47) Deane, H.W. and G.M.C. Masson: J. of Clin. Invest. $11: 209-212$, 1951.448 ) Deane, H.W. and J.M. Mc Kibbin: Endoc. 38: 385-400, 1946. 49) Deane, H.W. and A. Morse: Anat. Rec. $100: 127-141,1948 . \quad 50)$ Deane, H.W. and A.M. Seligman: Vitamin and Hormones 11: 173, $1953 . \quad 51)$ Deane, H.W. and J.H. Shaw.: J. Nutrit. 34: 1-19, $1947 . \quad$ 52) Deane, H.W., J.H. Shaw and R.O. Greep: Endoc. $43: 133-153,1948$. Delcastillo, E.B. and C.E. Rapela: Rev. Soc. argent. de biol. $21: 338-359.1945 . \quad$ 54) Dempsey, E.W.: Recent Prog. in Horm Res. $3: 127-157,1948 . \quad 55)$ Dempsey, E.W., R.O. Greep and H.W. Deane : Endoc. 44 : 88-103, $1949 . \quad$ 56) Desaulles, P., J. Tripod and W. Schuler: Schweiz. Med. W sehr. 83/45: 1088, 1953. 57) Dixon, H.B.F., M.P. Stack-Dunne, F.G. Young and D.B. Cata: Nature $168: 1084,1951$. 58) Domm, L. V. and P. Leroy: Anat. Rec. 109:395-396, 1951. 59 5osne, C. and A. J. Dalton: Anat. Rec. $80: 211-217,1941$.

60) Dribben, I.S, and J.M. Wolfe : Anat. Rec. 98 : 557-586, 1947. 61) Ducommun, P. and R. S. Mach: Acta Endoc. 3:17-26, 1949. (Feldman 1951より引用). Dugal, L.P. and M. Therien: Endoc $44: 420-426,1949$. 63) Earle, D.P., R.C. de Bodo, I.L. Schwartz, S. J. Farber, M. Kurtz and J. Greenberg: Proc. Soc. Exptl. Biol. \& Med. 76 : 608-612, 1951. Edmonds, H.W.: Arch. of Path. $50: 727-735,1950$.

65) Eichner, D. : Z. Zell forsch. $38: 488,1953$. 66) Ellison, E.T. and J.C. Burch: Endoc. 20: 746-752, 1936. 67) Engle, F.L., M.G. Winton and C.N.H. Long: J. Exptl. Med. 77 : 397-410, 1943.

68) Engstrom, H.: Anat. Anz. 83 : 1-19, 1936 (van Dorp, 
A.W. and H.W. Deane Anat. Rec. 107: 264, 1950より引用).

69) Evans, G. : Am. J. Physiol. 114 : 297-308, 1936

70) Evans, H.M., M.E. Simpson and C.N.H. Li. : Endoc. $33:$ 237-238, 1943.

Evans, H. M., R. I. Pencharz, K. Meyer and M. E. Simpson: Memor. Univ. of Calif. 2: 319, 1933 (Swann 1940より引用).

72) Everett, N.B. : Anat. Rec. $103:$ 335-349, 1949.

73) Farrell, G.L. and J.B.

Richards : Proc. Soc. Exptl. Biol. \& Med. 83 : 628-631, 1953.

74) Feldman, J.D. : Anat. Rec. 109 : 41-69, 1951.

75) Flexner, L.B. and A. Grollman: Anat. Rec. 75: 207-221, 1939.

76) Forsham,

P.H., G.W. Thorn, F.T.G. Prunty and A. G. Hills: J. Clin. Endoc. $8: 15-66,1948$.

77) Gaunt, R., C. Howell and N. Antonchak: J. Clin. Endoc. \& Med. 12: 958, 1952.

78) Gaunt, R., A.S. Gordon, A.A. Renzi, J. Padawer, G. J. Fruhman and M. Gilman : Endoc. 55 : 236-241, 1954.

79) Gount, R., C. H. Tuthill, N. Antonchak and J.H. Leathem : Endoc. $52: 407-423,1953 . \quad 80)$ Gemzell, C.A., D.C. van Dyke, C.A. Tobias and H.M. Evans, : Endoc. 49: 325-336. 1951.

81) Golla, Y.M.L. and M. Reiss:J. Endoc. 3: 5-9, $1942 . \quad$ 82) Gordon, M.L.: Endoc. $47: 13-18,1950$ 83) Gottschau, M.: Arch. f. Anat. u. Entwick, 412-458, $1883 . \quad$ 84) Graham, G.S. : J. Med. Res. 34:241-261, 1916. (Hoerr 1931より 引用). 85) Greep, R.O. and H.W. Deane : Endoc. $40: 417-425,1947 . \quad$ 86) Greep, R.O. and H.W. Deane : Endoc. 45 : 42-56, $1949 . \quad$ 87) Greep, R.O. and I.C. Jones : Recent. Prog. in Hormone Res. 5 : 197-261, $1950 . \quad$ 88) Gross, F. : Recent. Prog. in Horm. Res. 9 : 1954. (Gaunt et al Endoc. $55:$ 236-240, 1954より引用). 199 ) Gross, F. and H. Gysll : Acta Endoc. 15: 199, 1954 (Caunt, et al Endoc 55:236-240, 1954⿺り引用). 90) Gruenwald, P.: J. Morph. 70:353-387, 1942.91 91) Gruenwald, P. and W.M. Konikov: Anat. Rec. $89: 1-18,1944 . \quad 92)$ Grundy, H.M., S.A. Simpson, J.F. Tait and M. Woodford: Acta Endoc. 11:220, 1952 (Gaunt et al 1954より引用).

93) Haberer. H. und O. Stoerk: Sitzgsber Ges. Ärzte Wiens 21:2, 1908. Bachmann, R.: Handbuch der Mikroskopische Anatomie des Menschen. Fünfter Teil Die Nebenniere-Neurosekretion 1954. Berlin, Göttingen Heidelberg. $\quad 94)$ Hall, K.: J. Path. Bac. 51 : 75-82, 1940.

95) Hall, K. and V. Korenchevsky: J. Physiol. 91 : 365-374, 1938 (Rennels 1952 上り引用).

96) Hartman, F. A., K. A. Brownell and R. A. Knouff : Endoc. $41: 213-219,1947$. 97) Hariman, F.A. and K.A. Brownell: The Adrenal gland. Lea \& Febiger. Philadelphia. 1949. 98) Higgins, G.M. and D.J. Ingle : Endoc. 23 : 424-428, 1938. 99) Hills, A. G., P. H. Forsham and C. A. Finch: Blood. 3: 755-768, 1948. 100) Hoen, E., H. Lange feld and C. Aehme : Endokrinologie. $21: 305-314,1939 . \quad 101)$ Hoerr, N.L.: Am. J. Anat. $48: 139$ 193, 1931. 102) Homburger, F., S.C. Kasdon and W.H. Fishman: Proc. Soc. Exptl. Biol. \& Med. 74 : 162-164, 1950.103$)$ Houssay, B.A. ond R. Sammartino. : Compt. Rend. Soc. Biol. 114: 717-721, 1933. 104) Howard-miller, E.: Am. J. Anat. 40:251-293, 1927. 105) Ingle, D.J.: Am. J. Physiol. 124 : 627-630, $1938 . \quad 106$ ) Ingle, D. J. : Endoc. $24: 194-196,1939$. 107) Ingle, D. J. : Endoc. 29 : 649-652, 1941. $\quad 108)$ Ingle, D. J.: Endoc. 31: 419-438, 1942. 109) Ingle, D. J. and G. M. Higgins: Am. J. Med. Sci. 196: 232-239, 1938a. 110) Ingle, D. J. and G. M. Higgins : Endoc. 22 : 458-464, 1938b. 111) Ingle, D.J. and G.M. Higgins: Endoc. 23:419-423, 1938c. 112) Ingle, D.J. and G.M. Higgins : Endoc. $24: 379-382,1939 . \quad 113)$ Ingle, D.J., G.M. Higgins and E.C. Kendall : Anat. Rec. $71: 363-372,1938 . \quad 114)$ Ingie, D.J. and E.C. Kendall : Science $86: 245,1937.115$ ) Ingle, D.J., C.H. Li and H.M. Evans: Endoc. $39: 32-42$, $1946 . \quad 116)$ Ingle, D.J., M.C. Prestrud, C.H. Li and H.M. Evans: Endoc. $41: 170-176,1947 . \quad 117)$ Jayne, E.P.: Anat. Rec. $115: 459-483,1953$. 118) Jones, I.C. : Endoc. $45: 514-536,1949 . \quad 119)$ Jones, I.C. : Am. J. Anat. $86:$ 371-403, 1950. 120) Jost. A.: Compt. Rend. Sod. de Biol. 142: 273-275, 1948. (Kitchell, 1952ょり引用).

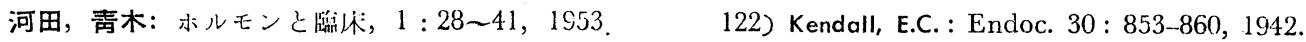
123) Kinsell, L.W., F. Olson, L. Boling, J. Partridge and S. Margen: J. Clin. Endoc. 11 : 1030-1033, 1951. 
124) Kitchell, P.L. and L. J. Wells: Anat. Rec. 112: 561-592, 1952.

125) Knigge, K. M. : Am. J. Anat. 94 : 225-272, $1954 . \quad$ 126) Knoff, R.A., J.B. Brown and B.M. Schneider: Anat. Rec. 79: 17-39, 1941. 127) Knowlton, A. I., E. N. Loeb, H. C. Stoerk and B. C. Seegal : J. Expt. Med. 85 : 187-198, 1947. 128) Knowlton, A. I., E. N. Loeb, B. C. Seegal and H. C. Stoerk: Endoc. 45: 435-445, 1949. 129) Kochakian, C.D. : Am. J. Physiol. $158:$ 51-56, 1949. Anat. 91 : Abt 1: 5-139, 1918. (Hoerr 1931より引用). 130) Kolmer. W.: Arch. f. mikroskop. Enooc. 49：481-483, 1951. 133) 金田：東京慈恵会医科大学杂隹誌，66：第 4 号，102１08，1952. 134) Lane, N.: Federation Proc. 10:78, 1951. (Baker, B. L. 1952 より引用). 135) Lane, N. and R. C. de Bodo: Am. J. Physiol. 168 : 1-19, $1952 . \quad 136)$ Leathem, J. H. and B. J. Brent: Proc. Soc. Exptl. Biol. \& Med. 52 : 241, $1943 . \quad$ 137) Leonard, S.L.: Proc. Soc. Exptl. Biol. \& Med. $51: 302-$ 303, 1942. 138) Leonard, S.L.: Endoc. $35: 83-90,1954 . \quad 139)$ Lewis, R.A., Salvador de Majo and E. Rosenberg: Endoc. 45 : 564-570. $1949 . \quad 140)$ Li, C.H., H.M. Evans and M.E. Simpson: J. Biol. Chem. 149: 413-424, 1943.

141) Long, C.N.H.: Bull New York Acad. Med. $23: 260-282,1947$ a. (Sayers 1950より引用).

142) Long, C.N.H.: Fed. Proc. 6: 461-471, 1947 b. (Sayers 1950より引用). 143) Ludewig, S. and A. Chanutin: Endoc. $41: 135-143,1947 . \quad$ 144) Luetscher, J. A. Jr and B. B. Johnson: J. Clin. Invest. $33: 276-286,1954 . \quad 145)$ Luft, R. and B. Sjogren: Nord. Med. 46: 1319, 1951. (Gaunt 1953より引用). 146) Lux, L., G.M. Higgins and F.C. Mann: Anat. Rec. 67: 353-365, 1937. 147) Mac Farland, W.E.: Anat. Rec. $93: 233-247,1945 . \quad$ 148) Mac Kay, E.M. and L.L. Mackay: J. Exptl. Med. 43 : 395-402, $1926 . \quad$ 149) Mackay, E.M. and W.O. Polland: J. Path. Bac. 34: 73-79, 1931. 150) Mattox, V.R., H.L. Masson and Albert: Proc. Staff. Meet. Mayo. Clinic. 28 : 569, $1953 . \quad$ 151) McPhail, M.K.: Proc. Roy. Soc. London Series B. $117: 45-63$, 1935. (Knigge, R.A. 1954より引用). 152) Meyer, R.K., C.H. Mellisch and H.S. Kupperman : J. Pharm. and Exptl. Therap. 65 : 104-114, $1939 . \quad$ 153) Miller, R.A.: Am. J. Anat. $86: 405-437,1950 . \quad 154)$ Miller, R.A. and O. Riddle: Proc. Soc. Exptl. Biol. \& Med. $41: 518-522,1939 . \quad 155)$ Miller, R. A. and O. Riddle: Am. J. Anat. 71 : 311-341, $1942 . \quad$ 156) Miller, R.A. and O. Riddle: Proc. Soc. Exptl. Biol. \& Med. 52: 231-233, $1943 . \quad$ 157) Mitchell, R.M.: Anat. Rec. 101:161-185, $1948 . \quad 158)$ 宮川: 日産婦誌, 5 : 9 号:953 955, 1953. 159) Moon, H.D.: Proc. Soc. Exptl. Biol. \& Med. $43: 42-44,1940 . \quad 160)$ 森：新撰内分泌学, 1955. 161) Mulon, P.: Compt. Rend. Soc. Biol. 55: 592-595, 1903. (Salmon 1941 より引用). 162) 中尾: 日新医学, 39:387 394, 1952. 163) Nathanson, I.T. aud A.M. Brues : Endoc. 29 : 397-401, 1941. 164) Nichois, J.: Arch. Path. 45:717-721, $1948 . \quad 165$ ) 大熥: 日内分泌学雑

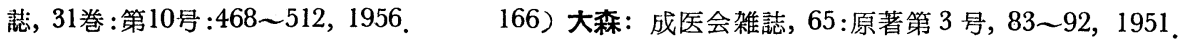
Orent-Keiles, E., A. Robinson and E.V. Mc Collum : Am. J. Physiol. 119: 651-661, 1937.1 168) Pearson, O.H.: Recent. Prog. in Horm. Res. $6: 1951 . \quad$ 169) Perla, D.: Proc. Soc. Exptl. Biol. \& Med. 32 : 655-658, $1935 . \quad$ 170) Popia'k G.: J. Path. and Bac. $56: 485-496,1944 . \quad 171)$ Reese, J.D. and H.D. Moon : Anat. Rec. 70 : 543-556, $1938 . \quad 172$ )Reifenstein, E.C. Jr., A.P. Forbes, F. Albright, E. Donaldson and E. Corroll : J. Glin. Invest. $24: 416-434,1945 . \quad 173)$ Rennels, E.G. : Anat. Rec. $112: 509-528$, 1952. 174) Riddle, O.: Cold Spring Harbor Symp. 5:262, 1937. (Swann 1940より引用).

175) Salmon, T.M. and R.L. Zwemer: Anat. Rec. $80: 421-427$. 1941. 176) Sarason, E.L.: Arch. Path. 35：373-390, 1943. 177) 佐藤：東京慈惠会医科大学雑誌，66:第 4 号，109１12, 1952.178 ) Sayers, G. and M.A. Sayers : Endoc. $40: 265-273,1947 . \quad 179)$ Sayers, G. and M.A. Sayers : Recent. Prog. in Horm. Res. 2: 81-115, $1948 . \quad$ 180) Sayers, G.: Physiol. Rev. $30: 241-320,1950.1181)$ Sayers, G., M. A. Sayers, E. G. Fry, A. White and C. N. H. Long: Yale J. Biol. Med. 16: 361-392, 1944 (Hartman 1949より引朋). 182) Sayers, G., M.A. Sayers, T.Y. Liang and C.N.H. Long: Endoc. $38: 1-9$, 
1946. 183) Sayers, G., A. Winter and C.N.H. Long : J. Biol. Ghem. $149: 425-436,1943$.

Schaffer, W. H.: Proc. Soc. Exptl. Biol. \& Med. $30: 1363-1365.1933 . \quad 185)$ Schour, I. and J.M. Rogoff : Am. J. Physiol. $115: 334-344,1936 . \quad 186)$ Schweizer, M. and M. E. Long. : 46: 191-206, 1950. 187) Selye, H.: Endoc. $21: 169-188$, 1937. 188) Selye, H.: J. Glin. Endoc. 6: 117-230, 1946.189$)$ Selye, H.: Textbook of Endoc. Acta Endoc. Inc. Montreal, Canada 1949. 190) Selye, H.: Stress. Acta Inc. Montreal 1950. 191) Selye, H. and C. Dosne: Proc. Soc. Exptl. Biol. \& Med. $44: 165$ 167, 1940. 192) Selye, H. and C. Dosne : Endoc. 30:581-584, 1942. 193) Selye, H. and H. Jensen: Ann. Rev. Biochem. 15:347-360, 1946. 194) Selye, H., E. M. Rowley and C.E. Hall: Proc. Exptl. Biol. \& Med. 54 : 141-143, $1943 . \quad$ 195) Selye, H. and H. Stone : On the Experimental Morphology of the adrenal cortex: Charles. G. Thomas Springfield 1950. 196) Shumacker, H.B. and W.M. Firor: Endoc. 18: 67ô-632, 1934 . 197) 島本: Acta Scholae Medicinalis Unv. Kioto, Jap. XXXIII, 1-44, 19j5. 193) Simpson, S. A., J. F. Tait, A. Wettstein, R. Neher, J.V. Euw and T. Reichstein : Experimentia $9: 333$, 1953. (Swingle,W.W. et al: Endoc. $54: 698-705,1954$ より引用). Rec. $32: 221,1926 . \quad 200)$ Smith, P.E. : Am. J. Anat. $45: 205-273,1930$. 199) Smith, P.E. : Anat. 38 : 402-403, $1946 . \quad$ 202) Smith, D.E.: Am. J. Physiol. 146: 133-139, 1946. 201) Smith, D.E. : Endoc. 203) 鈴木: 東等慈恵 会医科大学雑誌，66：第 4 号，42４7，1952. $\quad 204)$ Swann, H.G.: Physiol. Rev. 20: 493-521, 1940. 205) Swinyard, C. A. and H. A. Bruner: Endoc. $26: 886-890,1940 . \quad 206$ ) Talbot N.B., F. Albright, A.H. Saltzman, A. Zygmuntowicz and R. Wixon: J. Glin. Endoc. $7: 331-350,1947 . \quad 207$ ) 田所: Gumma.

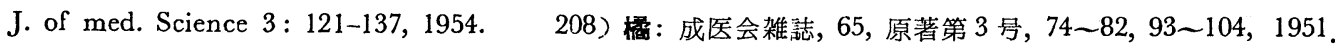
209) Tepperman, J., F. L. Engel and C. N. H. Long: Endoc. 32: 373-402, 1943. 210 ) Tobin, C. E.: Am. J. Anat. $65: 151-176,1939 . \quad 211)$ Turner, C.D. : Anat. Rec. $73: 145-162,1939 . \quad 212$ ) Vaccarezza A.J. : medicina 5: 425-445, 1945 (Deane H.W. and R.O. Greep, 1946より引用). 213) Waring, H. and E. Scott : J. Anat. $71: 399-414,1937$.

214) Weaver, H.M. and W. O. Nelson: Anat. Rec. 85 : 51-66, 1943. 215) Weber, M.: Diss. morbung. $1938 . \quad 216)$ Wells, B.B. and E.C. Kendell : Proc. Staff. Meet. Majo. Clinic. 15 : 133 and 5651940 (Stebbins, R. E. : Endoc. 49: 671, 1951より引用). 217) Wexler, B. C., A.P. Rinfret, A. C. Griffin and H. L. Richardson: Endoc. 56: 120-123, 1955. Whita, W. E. : Proc. Roy. Soc. London. Series. B. $114: 64-79,1933$ (Knigge, K.M. 1954 ๖り引用). 219) Wiesel, : Anat. Hefte $63: 19,481$ bis 522 1902. $\quad$ 220) Williams, R. G.: Am. J. Anat. 77 : 53-79, $1945 . \quad 221$ ) Williams, R. G.: Am. J. Anat. $81: 199-231,1947 . \quad 22)$ Winter, C. A. and F. E. Emery : Anat. Rec. 66 : 401-409, 1936. 223) Winter, C. A. and H. L. Hollings : J. Pharmacol. Exptl. Therap. $193: 366,1951 . \quad 224)$ Winter, C.A., H.L. Hollings and R.B. Stebbins: Endoc $52: 123-$ 134, 1953. 225) Winter, C. A., R. H. Silber and H. C. Stoerk: Endoc. $47: 60-72,1950 . \quad 226)$ Woodburg, D.M., C.P. Cheng, G. Sayers and L.S. Goodman: Am. J. Physiol. $160: 217-227,1950.227)$ Woolley, G.W.: Recent. Prog. in Horm. Res. $5: 383-405,1950 . \quad 228$ ) Woolley, G.M., E. Fekete and C.C. Little: Proc. Soc. Exptl. Biol. \& Med. 45: 796-798, 1940. 229) Woolley, G.M., E. Fekete and C.C. Little : Endoc. $28: 341-343,1941$ 230) Wotton, R.M. and R.L. Zwemer : Anat. Rec. 86: 409416, $1943 . \quad 231)$ Wyman, L.C. : Am. J. Physiol. $87: 29-41,1928 . \quad 232$ ) Yeakel, E.H.: Arch. Path. $44: 71-77,1947 . \quad 233$ ) Yoffey, J.M. and J. S. Baxter: J. Anat. $83: 89-98,1949$. (Feldman 1951より引用). 234) Zalesky, M.: Anat. Rec. 65:467-468, $1936 . \quad 235$ ) Zelesky, M., L.J. Wells, M.D, Ouer-holser and E.T. Gomez: Endoc. $28: 521,1941 . \quad 236$ ) Zizine, L.A., M.E. Simpson and H.M. Evans: Endoc. $47: 97-101,1950 . \quad$ 237) Zwemer, R.L.: Am. J. Pathol. 12 : 107-114, 1936 (Feldman 1951より引用). 238 ) Zwemer, R. L. and R. Truszkowski: Science 83: 558-560, 1936. 239) Zwemer, R.L., R.M. Wotton and M.G. Norkus : Anat. Rec. 72: 249-263, 1938. 
東森論文附図（其の 1 ）

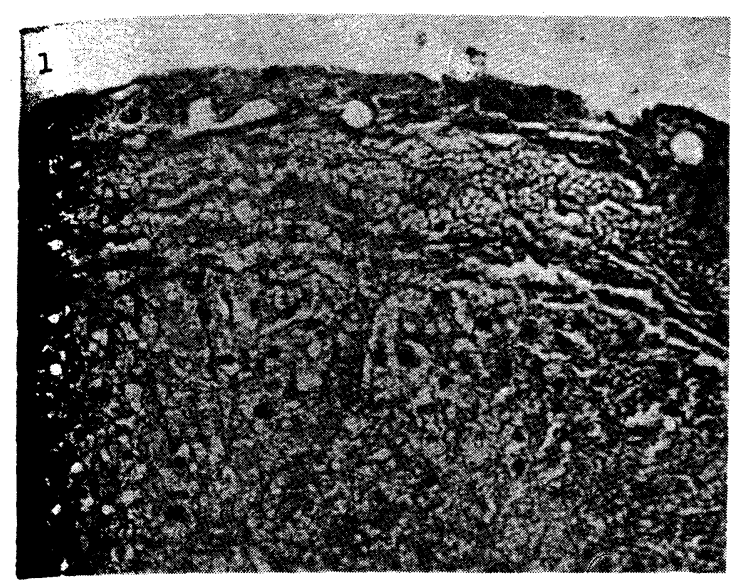

第 1 図

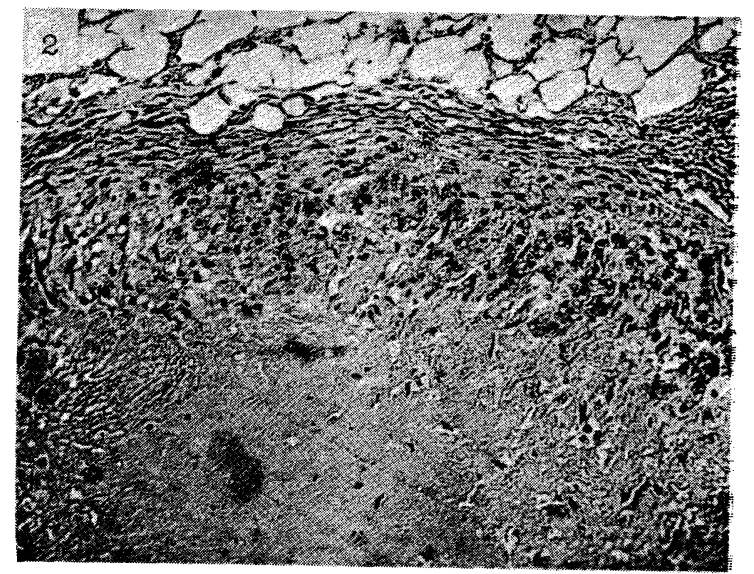

第 2 図

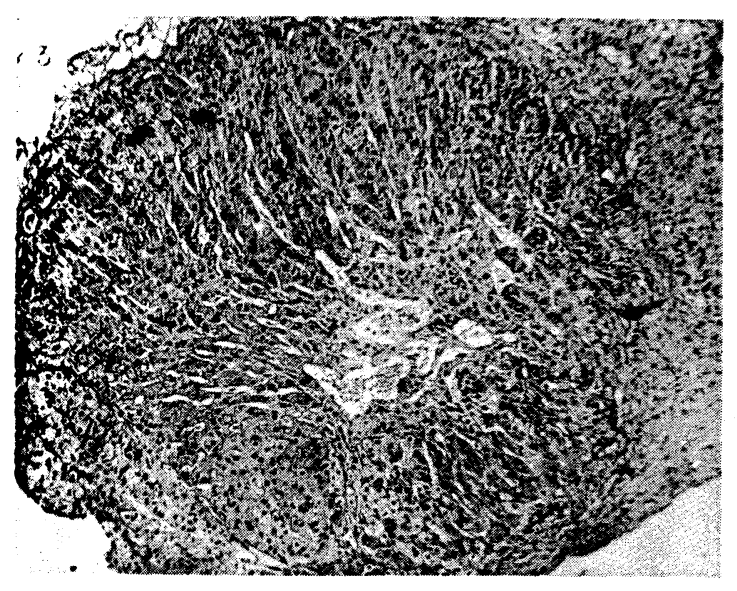

第3 図

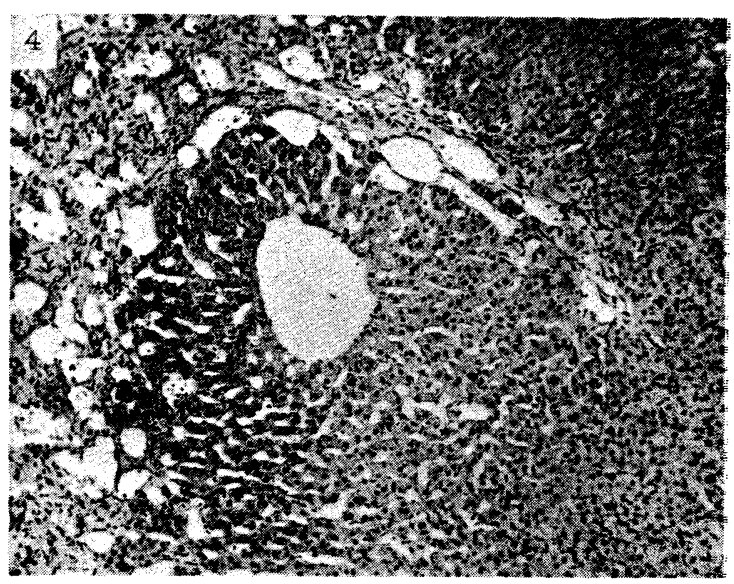

第 4 図

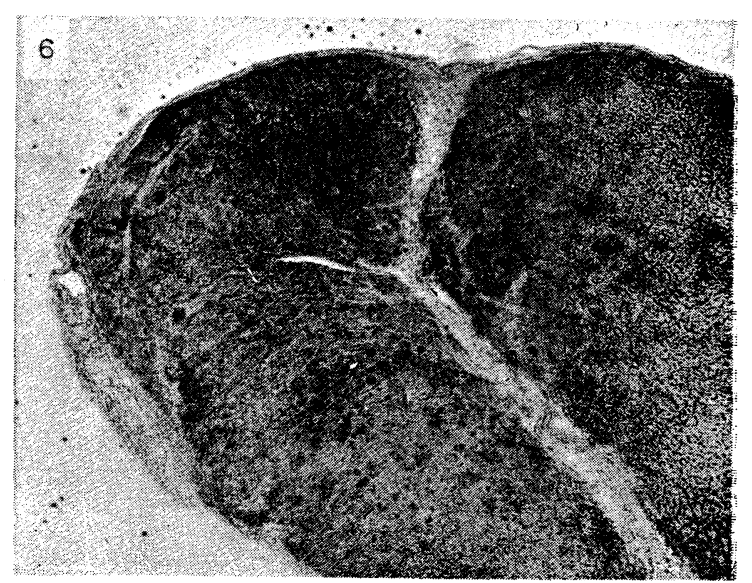

第 6 図 3.t.

第 5 図

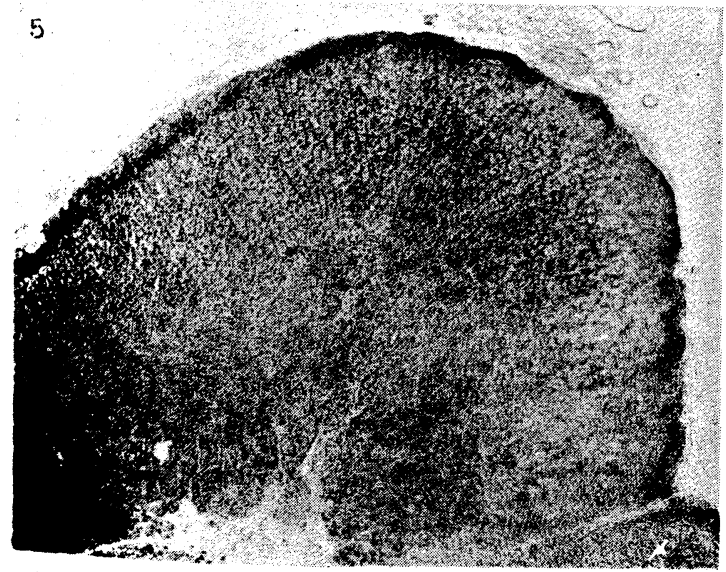

C 


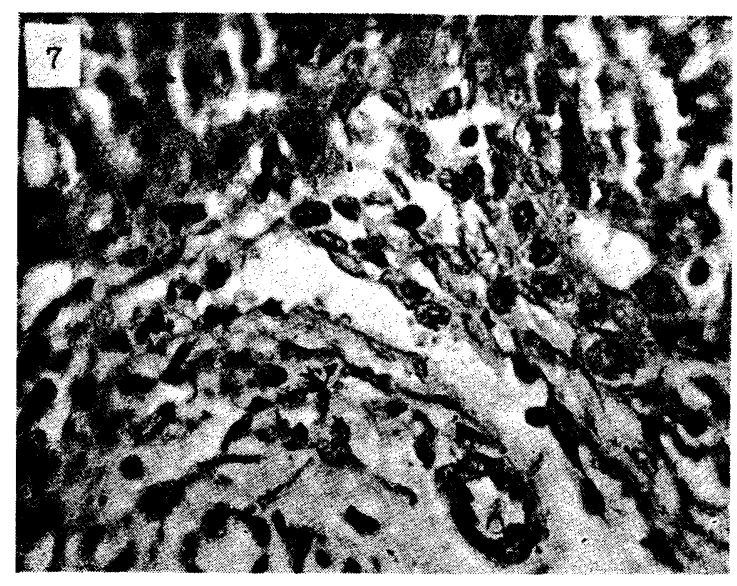

第7 図

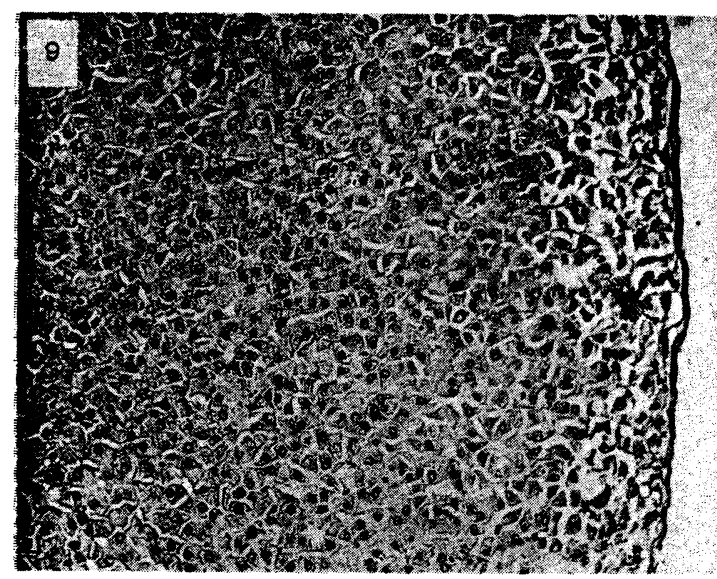

第9図

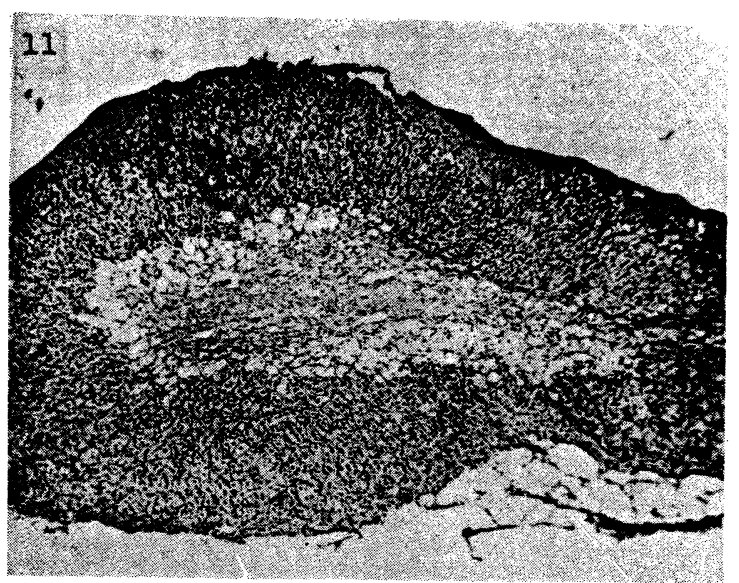

第11図

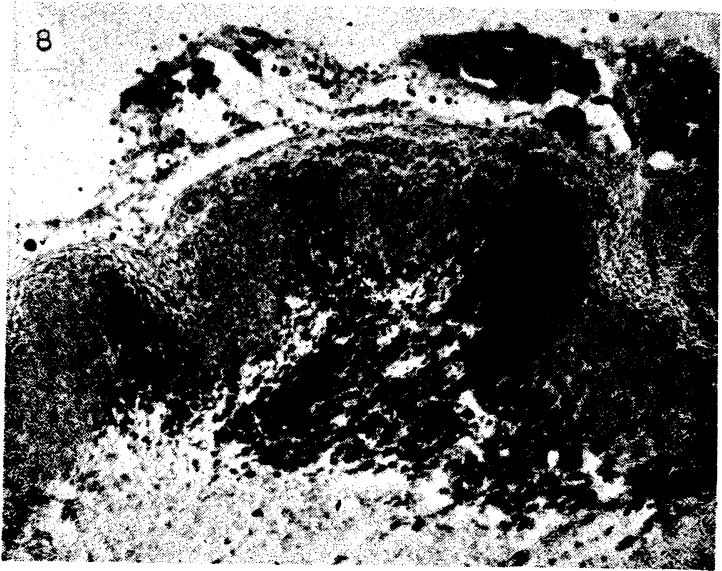

第 8 図

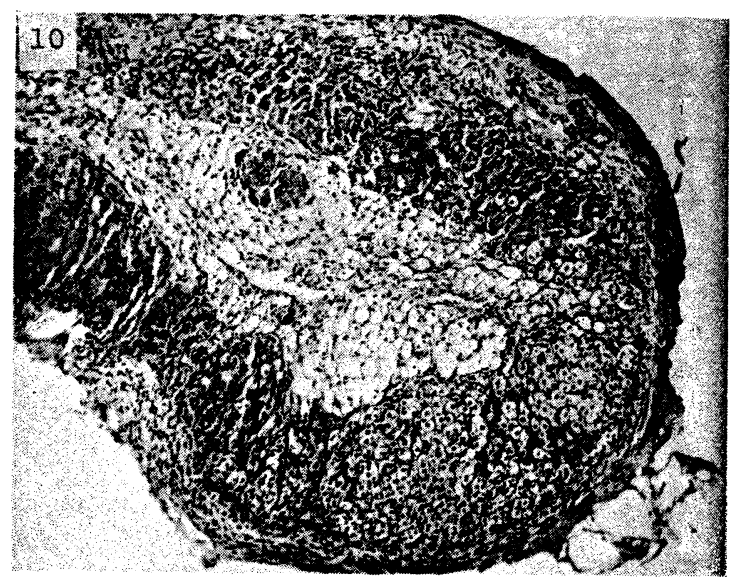

第10図

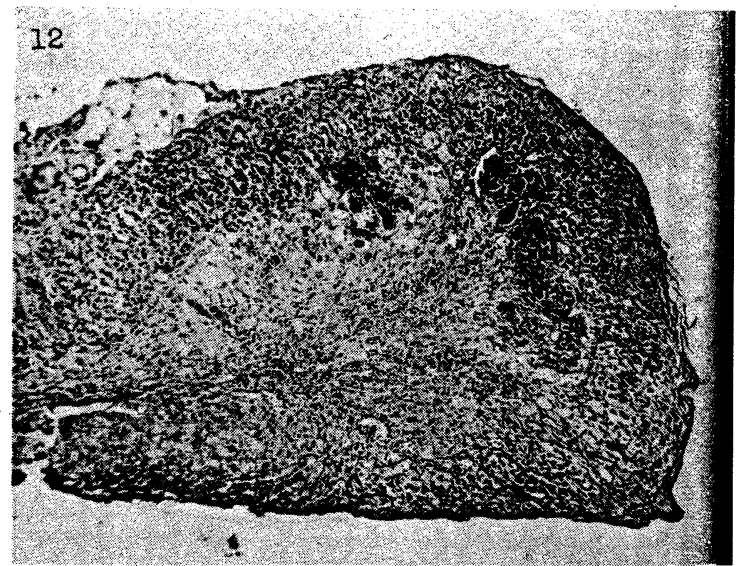

第12図 


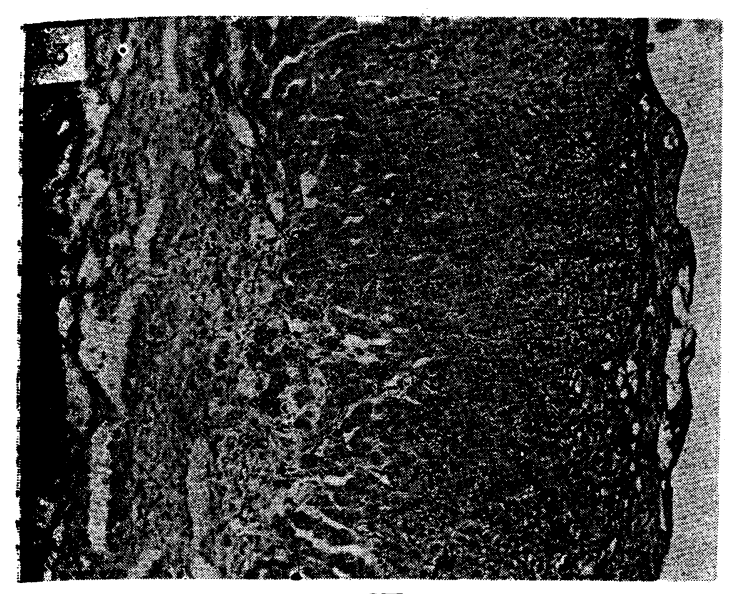

第13図

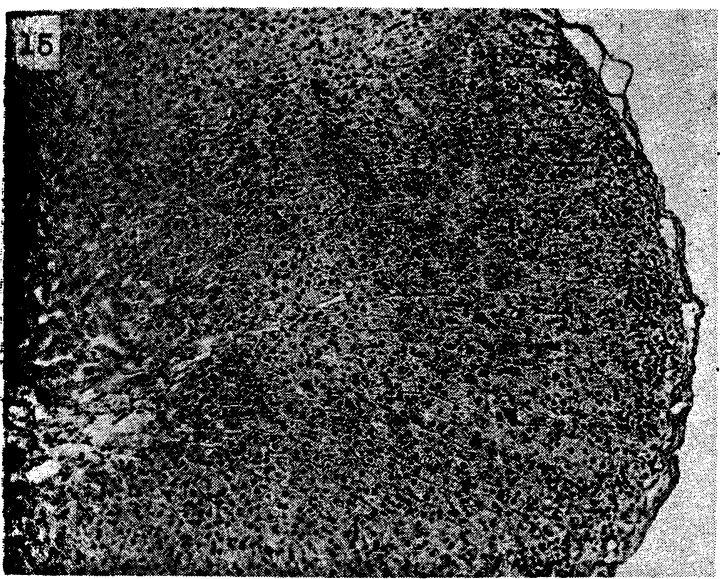

第15図

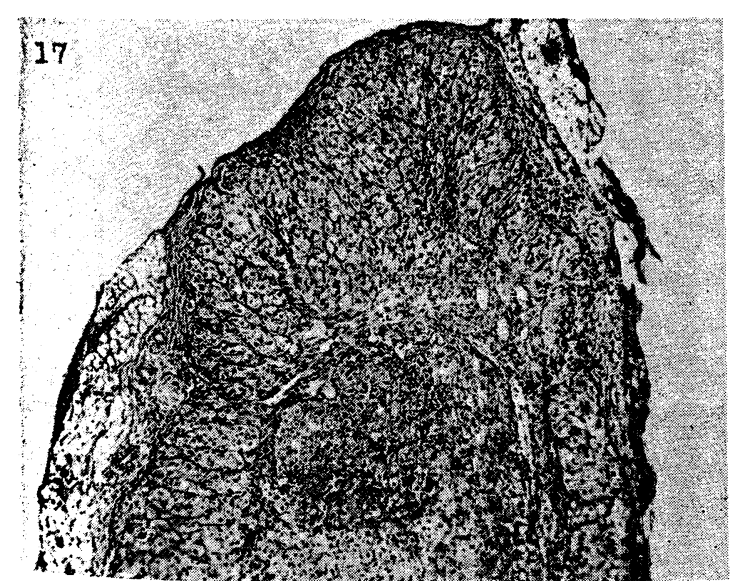

策17図

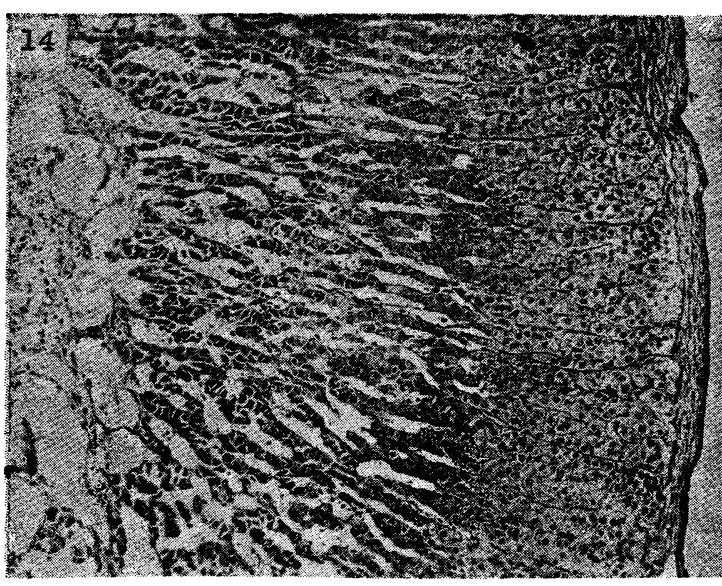

第14図
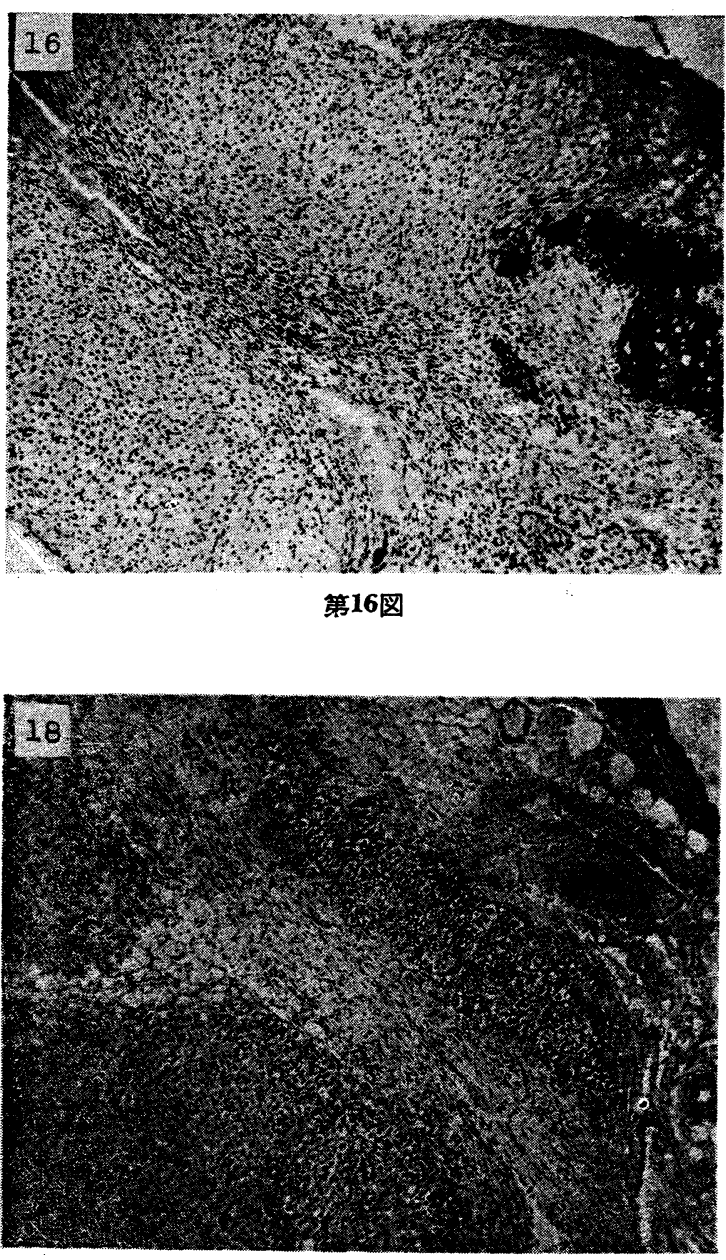

第18図 
東森論文附図（其の 4)

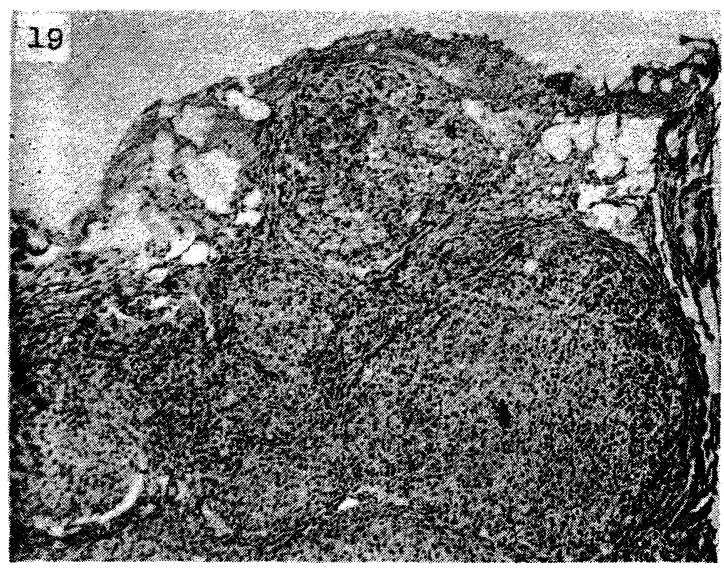

第19図

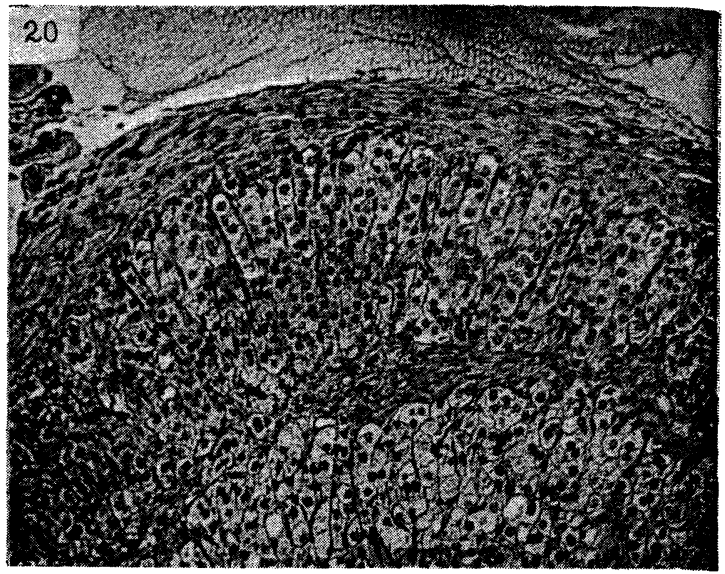

第20図

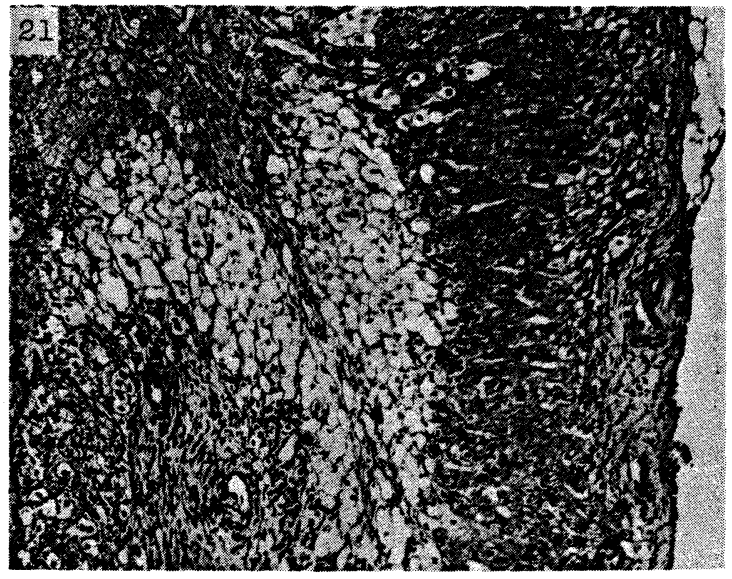

$$
\text { 第21図 }
$$
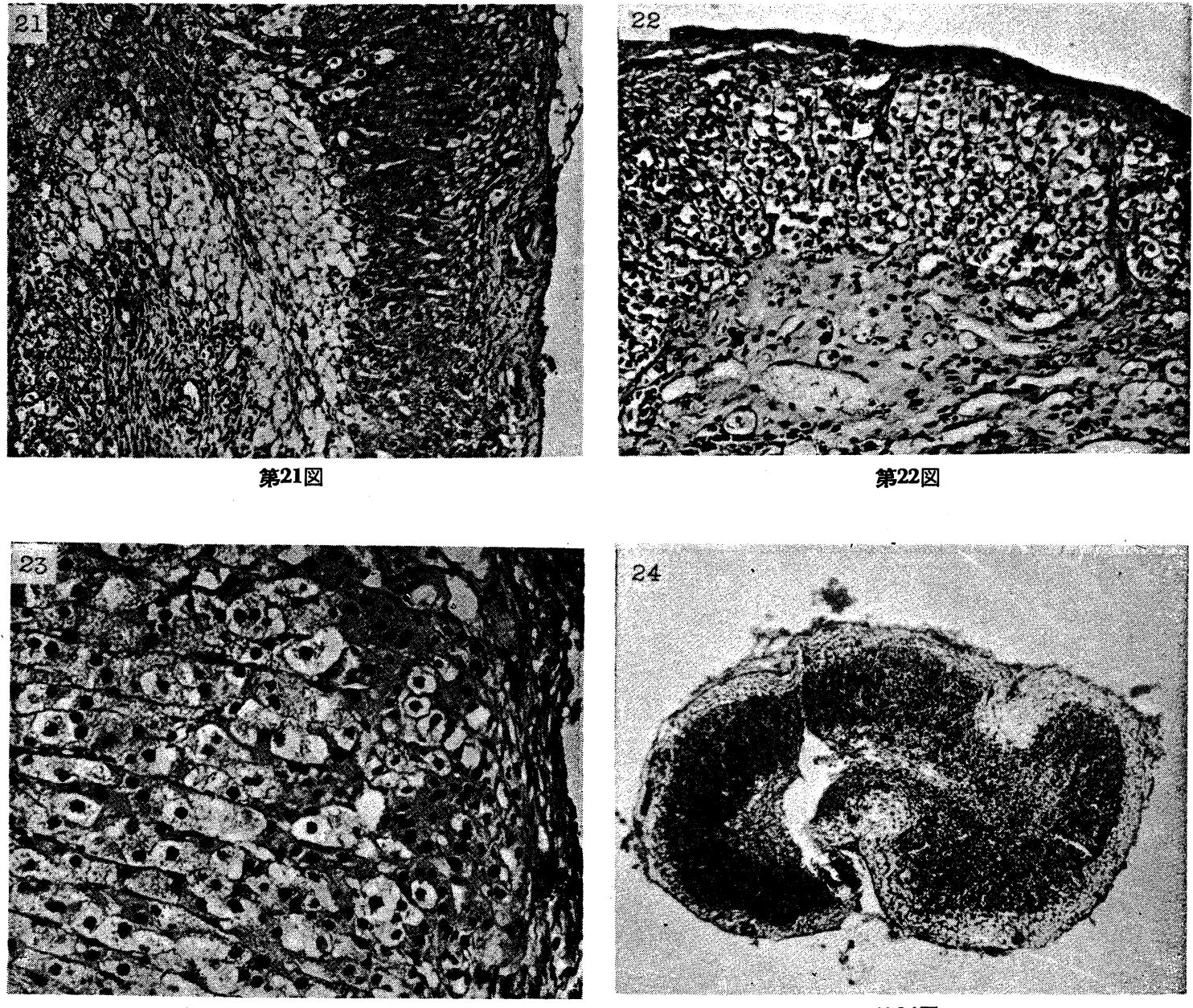
東 森論文附図（其の 5)

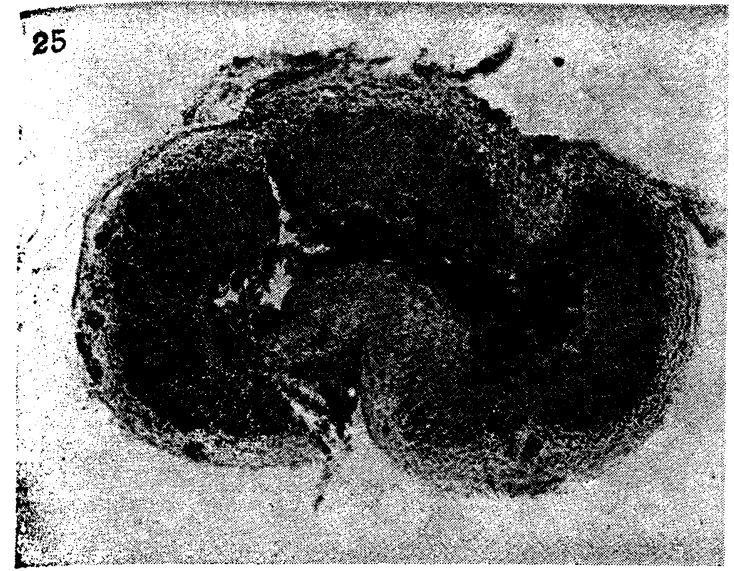

第25図

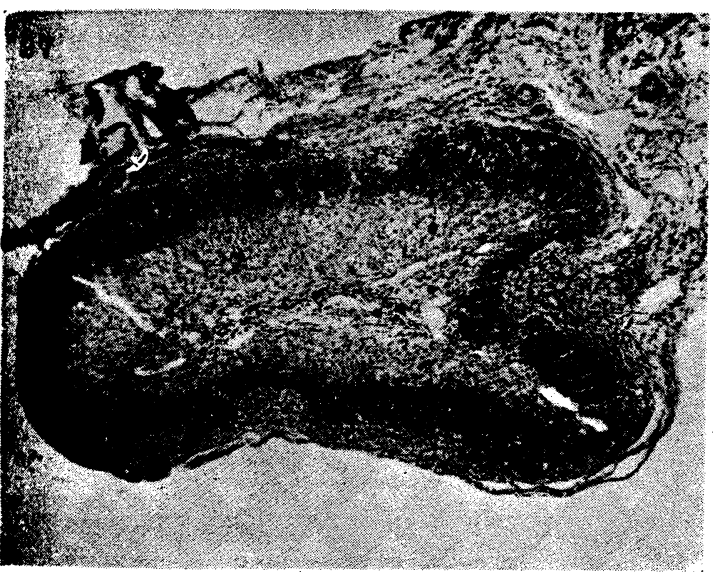

第27図

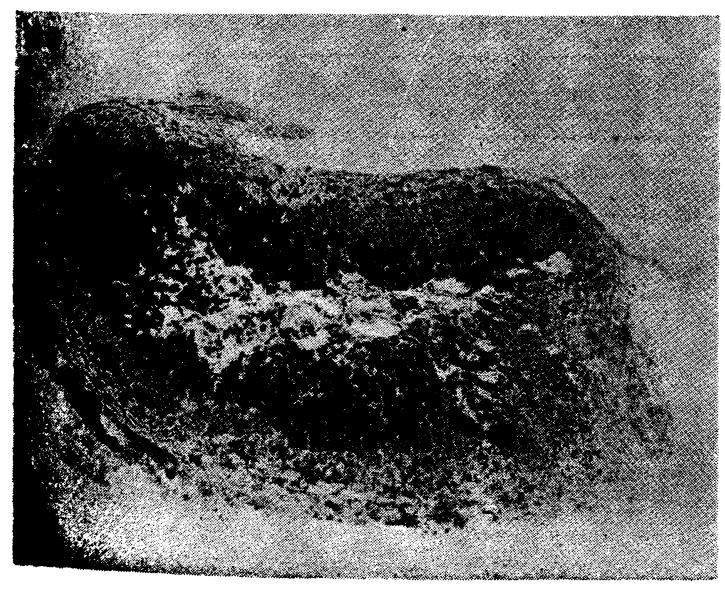

第29図

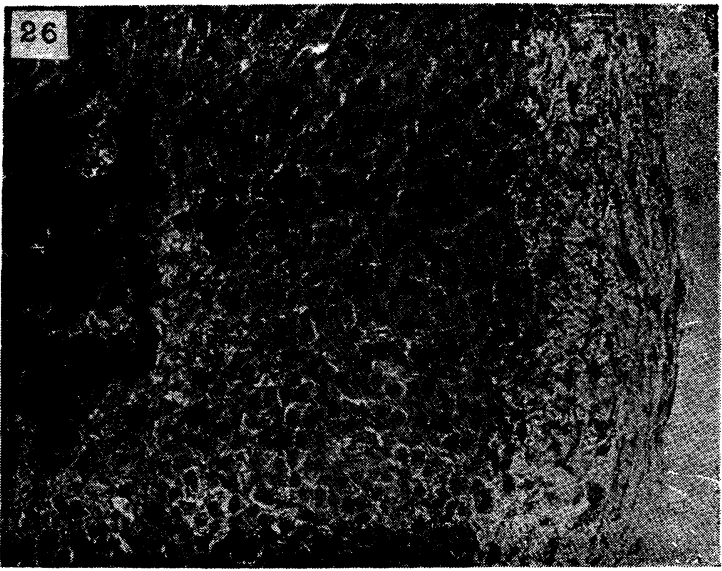

筫26図

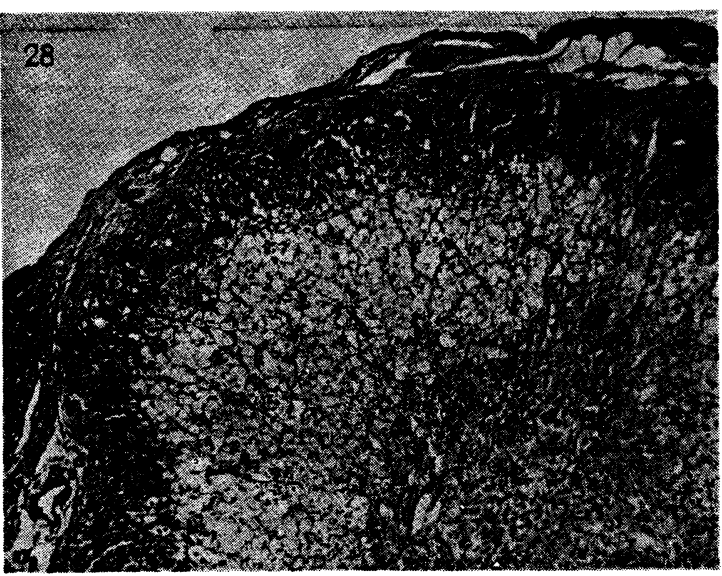

第28図

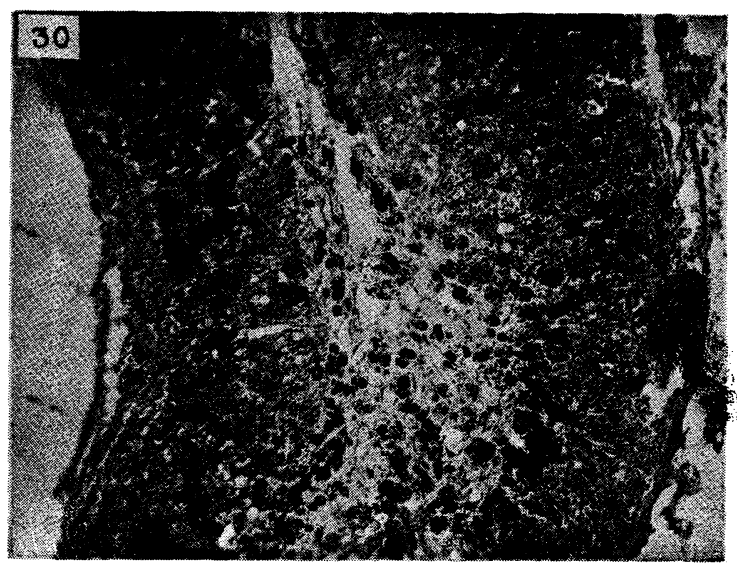

第30図 


\section{東 森 論 文 附図 (其の 6)}
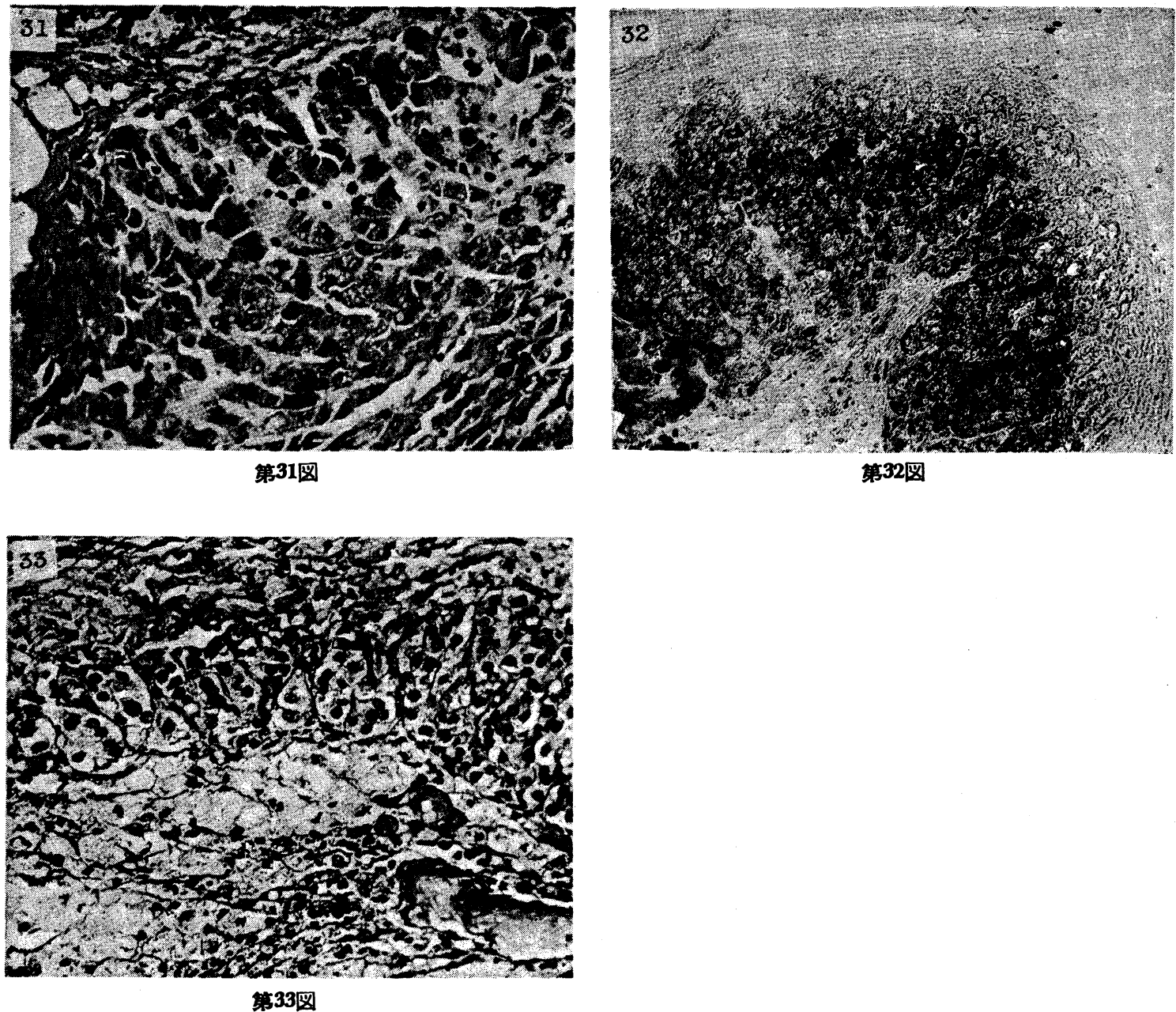